\title{
Pyrimidine: a review on anticancer activity with key emphasis on SAR
}

\author{
Aastha Mahapatra, Tanya Prasad and Tripti Sharma* (i)
}

\begin{abstract}
Background: Cancer is a global health challenge, it impacts the quality of life and its treatment is associated with several side effects. Resistance of the cancer cells to the existing drugs has led to search for novel anticancer agents. Pyrimidine, a privileged scaffold, is part of living organisms and plays vital role in various biological procedures as well as in cancer pathogenesis. Due to resemblance in structure with the nucleotide base pair of DNA and RNA, it is recognized as valuable compound in the treatment of cancer.

Main text: Many novel pyrimidine derivatives have been designed and developed for their anticancer activity in the last few years. The present review aims to focus on the structure activity relationship (SAR) of pyrimidine derivatives as anticancer agent from the last decade.

Conclusion: This review intends to assist in the development of more potent and efficacious anticancer drugs with pyrimidine scaffold.
\end{abstract}

Keywords: Pyrimidine, Anticancer activity, Structure activity relationship, Heterocyclic compounds

\section{Background}

Cancer is a life-threatening ailment worldwide [1]. Present treatment modalities like chemotherapy and radiotherapy suffers serious setbacks with multidrug resistance (MDR) being the major challenge. Search for diverse and novel structural framework may pave way to develop new effective anticancer drugs. Pyrimidine (1) is considered a vital heterocyclic moiety on account of its large spectrum of biological and pharmacological activities. These six-membered 1,3-diazine ring containing nitrogen at 1 and 3 position are part of naturally occurring substances such as nucleotides, nucleic acids, vitamins, coenzymes, purines, pterins, and uric acids. The widespread therapeutic applications of pyrimidine may be accounted for its presence in the structure of DNA and RNA. 5-halogenated derivatives of pyrimidine were among the first analogs tested for biological activity. This heterocyclic moiety is part of several drugs like

\footnotetext{
* Correspondence: triptisharma@soa.ac.in

Department of Medicinal Chemistry, Faculty of Pharmaceutical Sciences,

Siksha ' $\mathrm{O}$ ' Anusandhan (Deemed to be University), Bhubaneswar, Odisha 751003, India
}

zidovudine, stavudine, 5-flurouracil, methotrexate, imatinib, dasatinib, pazopanib, nilotinib, uramustine, tegafur, cytarabine, trimethoprim, sulfamethazine, minoxidil, phenobarbital, primidone, and risperidone $[2,3]$. This review emphasizes advances over the last decades in pyrimidine containing hybrids with in vitro anticancer potential and its correlation with the SAR.

\section{Main Text}

Pyrimidine derivatives as anticancer agent

Pyrimidine belongs to an electron rich nitrogen containing heterocycle. Synthetic versatility of pyrimidine allows generation of structurally diverse derivatives which includes analogs derived from substitution of the aryl ring, dervatization of pyrimidine nitrogen and substitutions at of carbon at 2, 4, 5, and 6 positions [4].

\section{Disubstituted pyrimidine derivative 2,4-Disubstituted pyrimidine derivative}

Some novel 2,4-disubstituted pyrimidines were developed and tested for antiproliferative activity using MTT assay with VX-680 as positive control. Compound 2 was

\section{Springer Open}

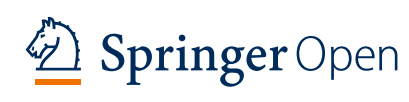

(c) The Author(s). 2021 Open Access This article is licensed under a Creative Commons Attribution 4.0 International License, which permits use, sharing, adaptation, distribution and reproduction in any medium or format, as long as you give appropriate credit to the original author(s) and the source, provide a link to the Creative Commons licence, and indicate if changes were made. The images or other third party material in this article are included in the article's Creative Commons licence, unless indicated otherwise in a credit line to the material. If material is not included in the article's Creative Commons licence and your intended use is not permitted by statutory regulation or exceeds the permitted use, you will need to obtain permission directly from the copyright holder. To view a copy of this licence, visit http://creativecommons.org/licenses/by/4.0/. 
moderate to highly active against the $\mathrm{A} 549\left(\mathrm{IC}_{50}=12.05\right.$ $\pm 0.45 \mu \mathrm{M}), \mathrm{HTC}-116\left(\mathrm{IC}_{50}=1.31 \pm 0.41 \mu \mathrm{M}\right)$, and MCF-7 $\left(\mathrm{IC}_{50}=20.53 \pm 6.13 \mu \mathrm{M}\right)$ cell lines and exhibited potent aurora kinase inhibition against both aurora $\mathrm{A}$ and $\mathrm{B}$ kinase. Apoptosis was induced due to upregulation of Bax and downregulation in Bcl-xl. The SAR studies suggests that the benzene ring when replaced with cyclohexyl group gave better activity and replacement of $\mathrm{NH}$ in urea with $\mathrm{CH}_{2}$ lead to decrease in activity [5]. It was established further that the blockade of G2-M phase of cell cycle occurred by accumulation of the contents at $\mathrm{S}$ phase due to decrease in mitochondrial membrane potential making 2,4-diaminopyrimidine derivatives potential anticancer agents. $3 \mathrm{a}\left(\mathrm{IC}_{50}=2.14\right.$ to $\left.5.52 \mu \mathrm{M}\right)$ and 3b $\left(\mathrm{IC}_{50}=1.98\right.$ to $\left.4.27 \mu \mathrm{M}\right)$ were most potent against the PC-3, A549, MCF-7, and HCT-116 cancer cell lines due to the variation of substitution on aromatic ring and terminal aniline on the pyrimidine moiety [6]. The induction of apoptosis was observed for cancer cell line K562 by novel anilino substituted pyrimidine sulfonamides. Cell viability was tested through MTT and tunnel assay. Compounds $\mathbf{4}(\mathbf{a}-\mathbf{c})$ demonstrated a promising activity with $\mathrm{IC}_{50}$ range $=5.6$ to $12.3 \mu \mathrm{M}$ [7]. Figure 1 depicts the chemical structure of 2,4-disubstituted pyrimidine derivatives.

\section{2,5-Disubstituted pyrimidine derivatives}

In 2015, Reddy and co-workers synthesized 2,5-disubstituted pyrimidines by Suzuki coupling and reported for moderate anticancer activity against the HeLa cell lines using MTT cell proliferation assay. Compound $\mathbf{5}\left(\mathrm{IC}_{50}=\right.$ $82.7 \mu \mathrm{M}$ ) showed the best activity (Fig. 2) [8].

\section{4,6-Disubstituted pyrimidine derivatives}

A series of novel 4, 6-disubstituted pyrimidine derivatives were evaluated for in vitro activities on cancerous cell lines SIHA, IMR-32, A549, PANC-1, DU145, and MDA-MB-231. 6a was found to be an efficacious inhibitor of IMR32, 6b in MDA-MB-231, and $\mathbf{6 c}$ in SIHA and DU145, whereas 6d in case of PANC-1 and A549 respectively. The SAR is depicted in Fig. 3 [9].

\section{Trisubstituted pyrimidines}

\section{2, 5, 6-Trisubstituted pyrimidines}

A new series of 2,4-diaminopyrimidines were reported as potent and selective aurora A kinase inhibitors. The best potency of the compounds was elucidated against HeLa, A-549, HCT-8, and Hep-G2 cells compared with the VX-680 as positive control by MTT assay. Compound 7 exhibited highest cytotoxicity with an $\mathrm{IC}_{50}=$ $0.5-4.0 \mu \mathrm{m}$ as well as led to cell cycle arrest in HeLa cells at G2/M phase [10].

\section{2, 4, 5-Trisubstituted pyrimidines}

New 5-alkyl pyrimidine derivatives, alkyl Nmethoxymethyl pyrimidine derivatives, and 5,6-dihydrofuro[2,3-d]pyrimidines were reported with cytostatic activities using 5-FU as the positive control. 5-chloroethyl2,6 dichloro pyrimidine $8\left(\mathrm{IC}_{50}=0.8 \pm 0.2 \mu \mathrm{M}\right)$ exerted cytostatic effect on HCT-116 cancer cell line which led to cell cycle arrest at G2/M phase due to DNA damage. The SAR suggests that the presence of two aromatic and an aliphatic chlorine atom linked to the pyrimidine ring gave the compound with maximum potential [11]. Furthermore, 2-arylaminopyrimidine derivative bearing a 2amino-N-methylbenzamide at $\mathrm{C} 4$ and chlorine at $\mathrm{C} 5$ positions were designed as a potent inhibitor of c-Met in cellular and enzymatic assays. $\mathrm{C} 2$ benzazepinone were found to be the most potent c-Met inhibitors, $9\left(\mathrm{IC}_{50}=\right.$ $10 \mathrm{nM}$ ) being the best analog. Incorporation of fluorine at C3 position of aminobenzamide moiety led to selectivity for c-Met kinase [12].

\section{2, 4, 6-Trisubstituted pyrimidines}

Recently, in a study of synthesis and anticancer activity of trisubstituted pyrimidines and their $\mathrm{N}$-alkyl derivatives was studied via ELISA, BRU, and MTT assay and 10 posed exceptional activity. They were tested against A549, Hep3B, HT29 FL, MCF-7, and HeLa cell lines with the $\mathrm{IC}_{50}$ range from 2 to $10 \mu \mathrm{m} / \mathrm{ml}$ [13]. Moreover, anthranillic acid ester moiety-linked 2,4,6-trisubstituted pyrimidines were tested for cytotoxic activty. The compounds were screened against U-937, CEM-13, MDAMB-231, DU-145, and BT-474 cancer cell lines by conventional MTT assays. 11a and 11b were known to be the most potent in the series and also as CDK9 inhibitors. The SAR studies reveal that the major activity is due to the (E)-styryl moiety at C-6 position, methyl group at $\mathrm{R}_{2}$ position, and the presence of methylanthranilate moiety with an EDG at C-4 lead to better activity (Fig. 4) [14].

Pyrimidines and triazolopyrimidines as antiproliferative agents exhibited COX-1/2 inhibitory potential. Compound $12\left(\mathrm{IC}_{50}\right.$ range $=8.68 \pm 0.2$ to $36.56 \pm 0.9$ $\mu \mathrm{g} / \mathrm{ml}$ ) displayed in vitro activity against cancer cell lines HepG-2, MCF-7, CaCo-2, and A549 alongside COX-2 inhibition using 5-FU as the reference drug [15]. Previously in a study, combretastatin bridged pyrimidine derivatives were tested for antitumor activity against the MCF-7 and A549 using MTT assay. 13a $\left(\mathrm{IC}_{50}=4.67\right.$ $\mu \mathrm{M} ; 3.38 \mu \mathrm{M})$ and 13b $\left(\mathrm{IC}_{50}=0.63 \mu \mathrm{M} ; 3.71 \mu \mathrm{M}\right)$ were concluded to have the best potential. 13a induced apoptosis by ROS-regulated intrinsic apoptotic pathway; they were non-toxic to harmful cells and were more potent inhibitors than cholchicne in the tunnel assay. The SAR demonstrated that the $R_{2}$ and $R_{3}$ substituted rings affected the activity, EWG such as 2,4-dichlorosubstitution 
<smiles>c1cncnc1</smiles><smiles>O=C(Cc1ccc(Nc2nccc(NC3CCCC3)n2)cc1)NC1CCCCC1</smiles>

2

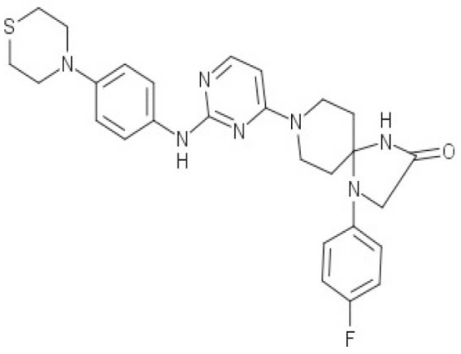<smiles>CC1CN(c2ccc(Nc3nccc(N4CCn5c(nnc5-c5ccc(F)c(Cl)c5)C4)n3)cc2)CC(C)N1</smiles>

3a<smiles>[R]O[As]Nc1ccc(C)c(Nc2nccc([R])n2)c1</smiles>

$\mathbf{3 b}$

4a; $\mathrm{R}_{1}=3$-pyridyl , $\mathrm{R} 2=3$ quinonyl

$4 \mathbf{b} ; \mathrm{R}_{1}=3,4,5$-Trimethoxyphenyl, $\mathrm{R}_{2}=4$ -

Biphenyl

$4 c ; R_{1}=3,4,5$-Trimethoxyphenyl, $\mathrm{R}_{2}=3,4-$

Dimethoxyphenyl

Fig. 1 Chemical structure of 2, 4-disubstituted pyrimidine derivatives

on the rings manifested good activity, and interchange of amine, methyl with hydrogen in $\mathrm{R}_{1}$ position of the pyrimidine ring displayed no activity. Replacement of rings with napthyl gave less activity and no substitution in any of the three rings also depicted activity [16].

In a library of $\mathrm{N}$-trisubstituted pyrimidine scaffold, compound $14\left(\mathrm{IC}_{50}=12.2 \mathrm{nM}\right)$ elucidated the best activity in the inhibition of U937 cell line. It caused the inhibition by inducing polyploidy $(4 \mathrm{~N}, 8 \mathrm{~N}$, and $16 \mathrm{~N})$ in the cancer cells by inducing defects in both chromosome formation and spindle formation. The SAR studies are depicted in Fig. 5 [17].

In a continued study, a series of pyrimidinebenzimidazole compound $\mathbf{1 5}$ with an $\mathrm{IC}_{50}=1.06$ to $12.89 \mu \mathrm{M}$, was tested against the MGC-803, SMMC7721, EC-9706, and MCF-7 cell lines antiproliferative activity. The cell cycle came to rest at G2/M phase by the active compound accompanied by an increase in apoptotic cell death of MGC-803 [18]. Additionally, in the previous year, the novel thiazolopyrimidine derivatives were studied against the human cancer cell lines and primary CLL cells. 16 displayed excellent anticancer activity against the cell lines and led to cell death by apoptosis as it inhibited the CDK enzyme [19].

Evaluation for pharmacological activity was conducted for some novel 1, 2, 4-triazole containing pyrimidine derivatives. $\mathbf{1 7}(\mathbf{a}-\mathbf{b})$ were found to have effective activity on HOP-92 as evaluated using the MTT assay [20]. In an earlier work, MTT assay was conducted to determine cytotoxic study of the series novel pyrimidine derivatives 18a (\% inhibition at $50 \mu \mathrm{g} / \mathrm{mL}=43.62$ ) containing 4chlorophenyl substitution on 6th position of pyrimidine 


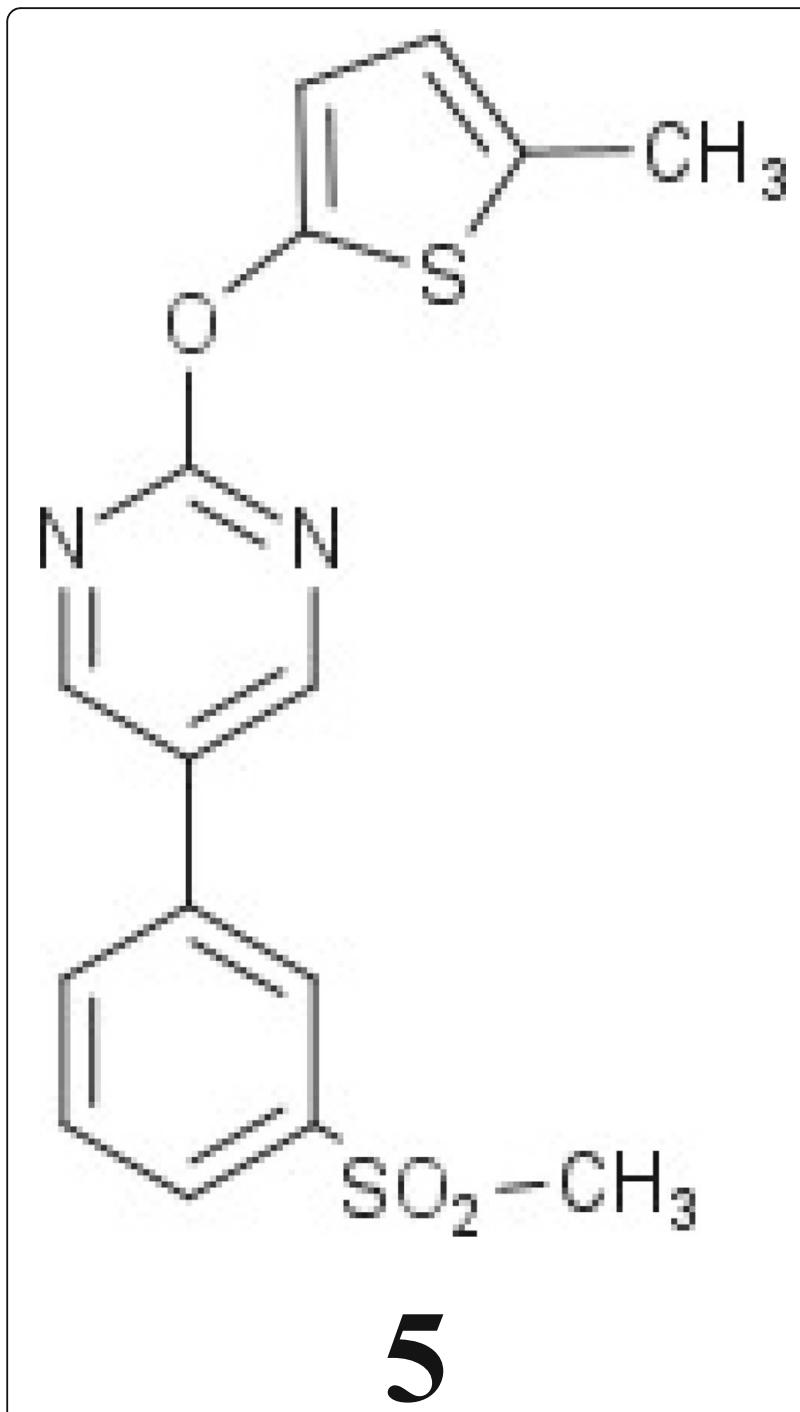

Fig. 2 Chemical structures of 2,5-disubstituted pyrimidine derivatives nucleus and 18b (\% inhibition at $50 \mu \mathrm{g} / \mathrm{mL}=39.52)$ containing thiophene ring, showed the most potency. The SAR revealed that the most of the activity was due to the substitution of mono or di chlorine at the R1 position of the phenyl ring [21].

The in vitro anticancer activity of novel pyrimidine derivatives was reported in which it was concluded that $\mathbf{1 9}$ showed the best activity against the whole panel of 60 cancer cell lines (especially lung cancer cell lines). The cell lines were tested at different concentration of the compounds, and the SAR studies revealed that the EDG groups like $\mathrm{NH}_{2}$ and EWG like $\mathrm{Cl}$ and $\mathrm{C}=\mathrm{O}$ at orthoand paraposition of the ring is highly influential for the activity (Fig. 6) [22].

\section{Tetrasubstituted pyrimidine derivatives 2,4,5,6-Tetrasubstituted pyrimidines}

A study reported ER $\alpha$ and VEGFR-2 ligands in the form of 2, 4-disubstituted pyrimidine derivatives and tested them against the MCF-7 cancer cell lines. 20 had ER $\alpha$ binding affinity $\left(\mathrm{IC}_{50}=1.64 \mu \mathrm{M}\right)$ and inhibition activity against VEGFR-2 $\left(\mathrm{IC}_{50}=0.085 \mu \mathrm{M}\right)$. It acted by suppressing the progesterone inhibition mRNA and in vivo angiogenesis inhibition in CAM assay. Suppression of cell migration, apoptosis, and transduction reticence of Raf-1/MAPK/ERK in MCF-7 cells were also reported. SAR studies showed that the hydrogen bonding interaction at the head is significant for increase in ER $\alpha$ binding affinity (Fig. 7) [23].

A series of pyrimidines including thioxopyrimidine, iminopyrimidine, bicyclic thiazolopyrimidine, and arylidine derivatives of thiazolopyrimidine were reported for anticancer activity and studied against HCT-116, PC-3, and Hep-2 cancer cell lines. Compound 21a, 21b, and 21d exhibited higher activity against $\mathrm{PC}-3$ with $\mathrm{IC}_{50}=$ $66.6 \pm 3.6 \mu \mathrm{g} / \mathrm{ml}, 69.6 \pm 2.1 \mu \mathrm{g} / \mathrm{ml}$, and $65.8 \pm 2.8 \mu \mathrm{g} / \mathrm{ml}$

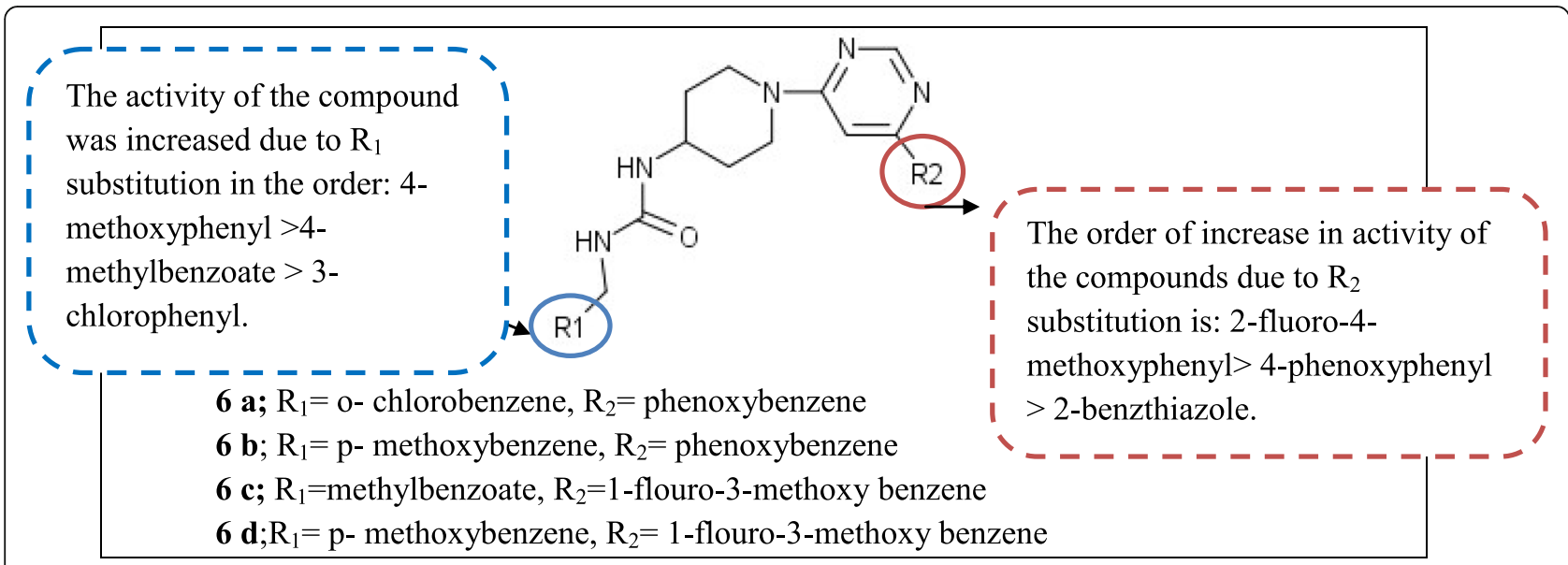

Fig. 3 Chemical structures and SAR studies of novel 4, 6-disubstituted pyrimidine compounds 
<smiles>CN1CCC(NC(=O)c2ccc(Nc3ncc(Br)c(NC4CCCC4)n3)cc2)CC1</smiles>

7

8<smiles>CCN1C(=O)CCC(C)(C)c2ccc(Nc3ncc(Cl)c(Nc4c(F)cccc4C(=O)NC)n3)cc21</smiles>

9<smiles>[R]c1cccc(/C=C/c2cc(-c3ccc(NC(C)=O)c(C(C)=O)c3)nc([R])n2)c1</smiles>

11a; $\mathrm{R}_{1}=2,3-\mathrm{OMe}$;

$11 \mathrm{~b} \mathrm{R}_{1}=2,5-\mathrm{OMe}$

$\mathrm{a}-\mathrm{b} ; \mathrm{R}_{2}=\mathrm{Me}$<smiles>[R2]c1cc([R9])nc([R1])n1</smiles>

13a $; \mathrm{R}_{1}=\mathrm{CH}_{3}, \mathrm{R}_{2}=\mathrm{R}_{3}=\mathrm{C}_{6} \mathrm{H}_{5}$

13b; $\mathrm{R}_{1}=\mathrm{NH}_{2}, \mathrm{R}_{2}=3,4,5$-trimethoxy phenyl $\mathrm{R}_{3}=2,4-\mathrm{Cl}$<smiles>COc1ccc(-c2cc(-c3cc[n+]([13F])cc3)nc(N)n2)cc1</smiles>

10<smiles>Cc1ccc(-c2cn(-c3ccccc3)/c(=N/Nc3cc(C)nc(SCc4ccccc4)n3)s2)cc1</smiles>

12

Fig. 4 Chemical structures of trisubstituted pyrimidine derivatives

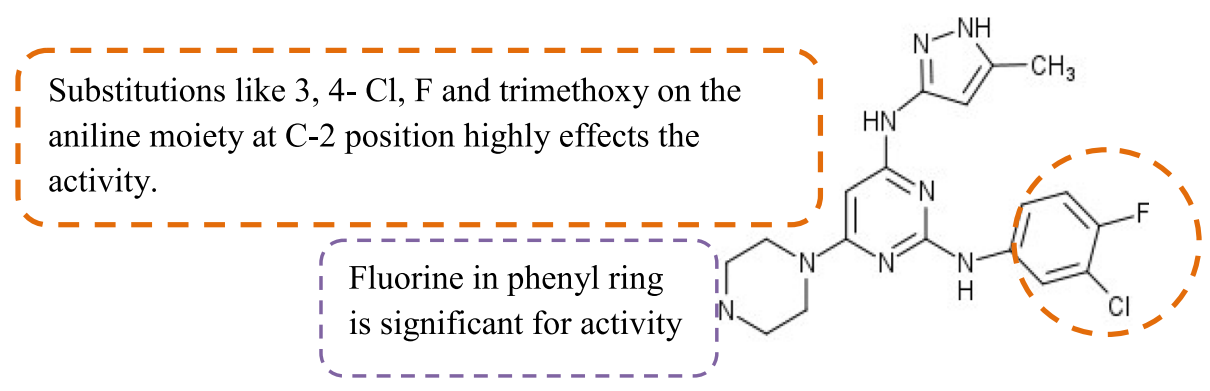

14

Fig. 5 Chemical structure and SAR studies of trisubstituted pyrimidine 
<smiles>COc1ccc(Nc2cc(-c3ccccc3)nc(Sc3nc4cc(Cl)ccc4[nH]3)n2)cc1</smiles>

15<smiles>[R1]c1cc(-c2cc(C)oc2C)nc(N)n1</smiles>

18a; $\mathrm{R}_{1}=4$ "-chlorophenyl<smiles>CNc1nc(C)c(-c2nc(Nc3cccc(Br)c3)ncc2C#N)s1</smiles>

$\mathbf{1 6} ; \mathrm{R}_{1}=\mathrm{m}-1,4-$ diazepan-1-yl<smiles>[R]C1C=C(n2nc(-c3ccccc3)nc2-c2ccccc2)N=C(S)N1</smiles>

17a; $\mathrm{R}=4$-Chlorophenyl 17b;R=4-Methoxyphenyl<smiles>Nc1nc(-c2ccccc2Cl)cc(-c2ccc(Cl)cc2Cl)n1</smiles>

19

\section{8b; $\mathrm{R}_{1}=2$ ", 4"-dichlorophenyl}

Fig. 6 Chemical structures of some 2,4,6-trisubstituted pyrimidine derivatives

respectively whereas $\mathbf{2 1 c}$ and $\mathbf{2 1 d}$ showed higher activity against HCT-116 $\left(\mathrm{IC}_{50}\right.$ values $60.9 \pm 1.8 \mu \mathrm{g} / \mathrm{ml}$ and $58.2 \pm 5.1 \mu \mathrm{g} / \mathrm{ml})$. The SAR study is illustrated in Fig. 8 [24].

A novel series of 2,4-disubstituted-2-thiopyrimidine derivatives was reported as VEGFR-2 inhibitor and tested against the HepG2 and UO-31 cancer cell lines. 22a $\left(\mathrm{IC}_{50}=1.23 \mu \mathrm{M}\right)$ and 22b $\left(\mathrm{IC}_{50}=3.78 \mu \mathrm{M}\right)$ were found to be active inhibitor of VEGFR-2 as well as

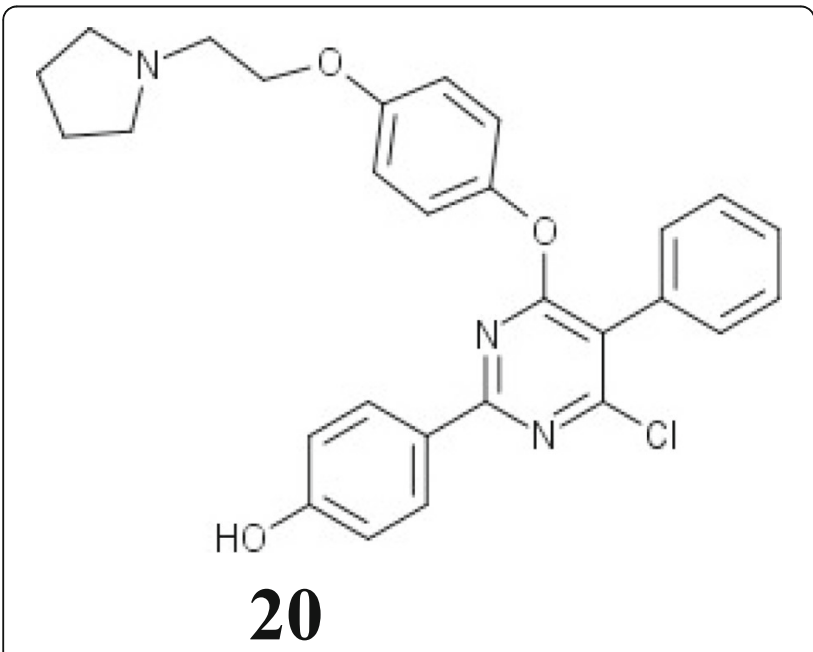

Fig. 7 Chemical structure of tetrasubstituted pyrimidines derivatives displayed activity against $\mathrm{HePG} 2$ with the $\mathrm{IC}_{50}=13.06$ $\mu \mathrm{M}$ and $\mathrm{IC}_{50}=8.35 \mu \mathrm{M}$. The SAR studies reveal that the potency was due to the hydrophobic interaction of the substitutions at position-2 and phenyl group at position4 of thiouracil moiety [25].

Pyrimidine substituted with 1, 2, 3-triazole-urea was screened for oncogenic activity against MGC-803, B16F10, EC-109, and MCF-7 cancer cell lines. Compounds 23a, 23b, and 23c were reported to exhibit potent activity against B16-F10 with an $\mathrm{IC}_{50}=32 \mathrm{nM}, 35 \mathrm{nM}$, and $42 \mathrm{nM}$ respectively. The SAR revealed that the electronic effect on the phenyl ring affects the activity, an EDG group, gives more activity and at $R_{1}$ the presence of 4methyl and 4-methoxyl attributes better activity than 2methyl, 3-methyl, and 2-methoxyl substitutions [26]. Additionally, anticancer activity of pyrimidine-thiourea derivatives was studied. The derivatives inhibited histone LSD1 which was over expressed in many tumor cells. Compound $24\left(\mathrm{IC}_{50}=0.65 \pm 0.12 \mu \mathrm{M}\right)$ was most potent against gastric cancer cell line and it inhibited cell migration and invasion with tumor suppressing and antimetastasis functions. Amino, thio, and urea groups are essential for the LSD-1 inhibition. Thio urea instead of urea offered better activity and subsequently the proprgyl and trimethoxy phenyl group increases anticancer activity (Fig. 9) [27].

1, 2, 3-Triazole substituted pyrimidines were studied for anticancer activity against the MGC-803, EC-109, 


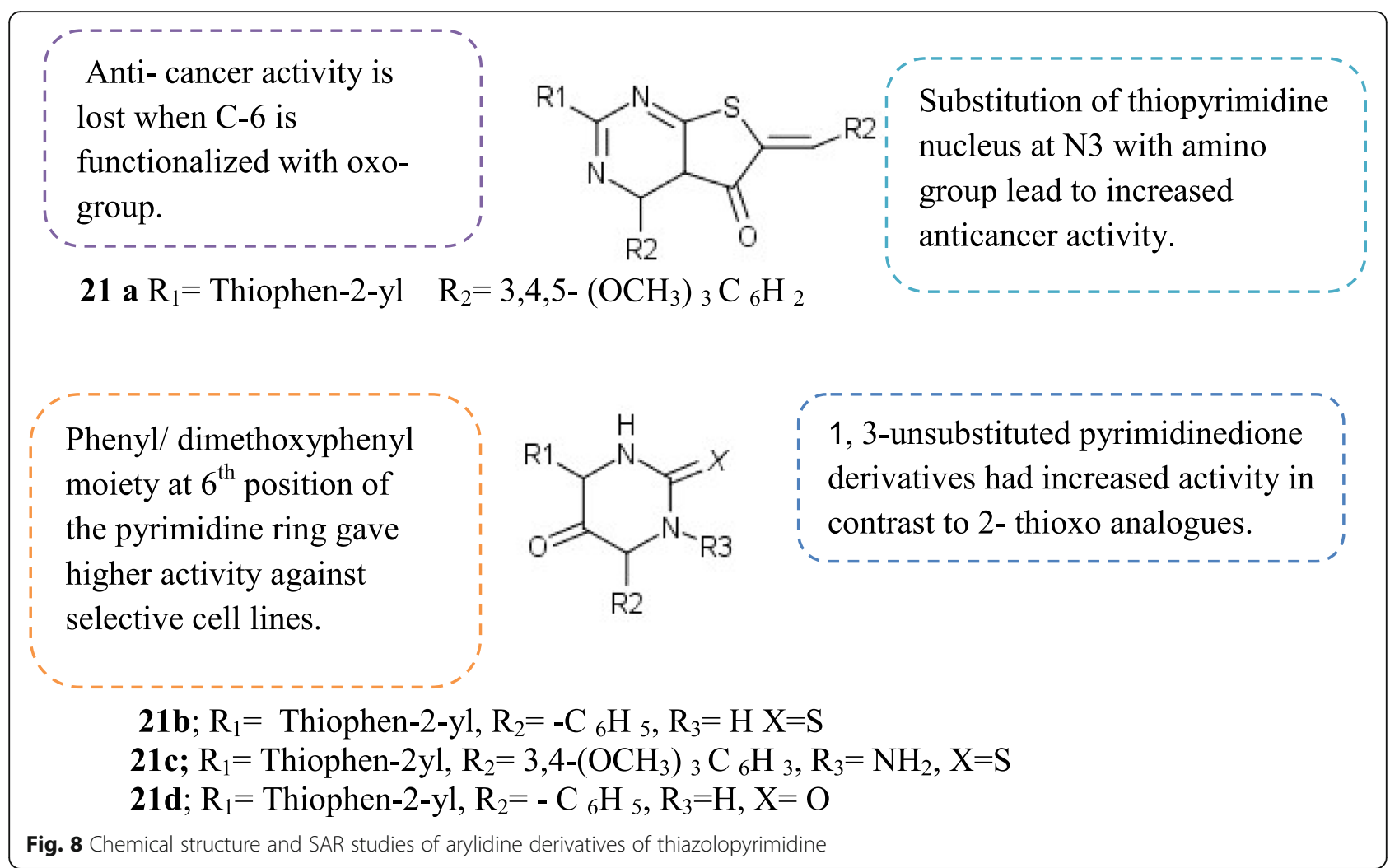

MCF-7, and B16-F10 cancer cell lines with 5-FU as positive control. Compound $\mathbf{2 5}\left(\mathrm{IC}_{50}=1.42\right.$ to $\left.6.52 \mu \mathrm{M}\right)$ was the most potent and induced apoptosis as well as arrested cell cycle at G2/M phase in EC-109 cells. The main activity was due to presence of triazole moiety, substitution at 2 position of benzyl group, and substitution at 4 position of arylamine group with an EDG than at 3 positions [28]. 4-Substituted thiopyrimidine analogs were reported and tested against 60 cancer cell line panel. 26a and 26b depicted high potential against the leukemia cell lines. SAR is given in Fig. 10 [29].<smiles>[R]c1ccc(C(=O)CSc2nc(-c3ccc([R])cc3)c(C#N)c(=O)[nH]2)cc1</smiles>

22a; $\mathrm{R}_{1}=4-\mathrm{OMe}, \mathrm{R}_{2}=4-\mathrm{OMe}$ 22b; $\mathrm{R}_{1}=4-\mathrm{OMe} \quad \mathrm{R}_{2}=2-\mathrm{OMe}$

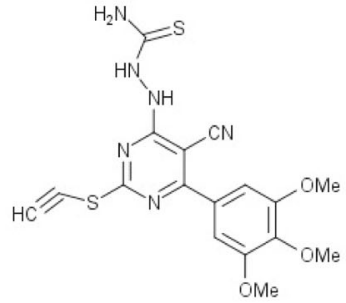

24

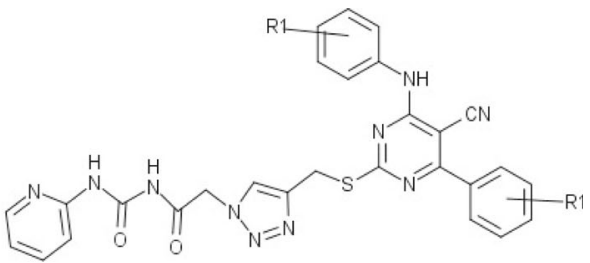

23a; $\mathrm{R}_{1}=p-\mathrm{CH}_{3} ; \mathrm{R}_{2}=m, p, m-\left(\mathrm{OCH}_{3}\right)_{3}$ 23b; $\mathrm{R}_{1}=p-\mathrm{CH}\left(\mathrm{OCH}_{3}\right)_{2} ; \mathrm{R}_{2}=p-\mathrm{CH}_{3}$ 23c $; \mathrm{R}_{1}=p-\mathrm{CH}\left(\mathrm{CH}_{3}\right)_{2} ; \mathrm{R}_{2}=p-\mathrm{Br}$

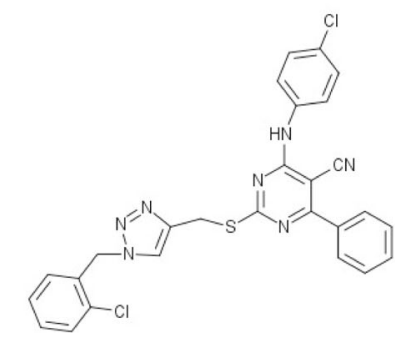

25

Fig. 9 Chemical structures of tetrasubstituted pyrimidine derivatives 
An active chlorine atom at

\section{$\mathrm{R}_{2}$ position gives more} activity compared to the piperidine moiety. Sulfamethoxazole moiety increased activity.
Morpholino derivative at $\mathrm{R}_{2}$ is more preferred than piperidino congener.

Fusion of thiazolone ring with the pyrimidinone nucleus results in low activity.

26a; $\mathrm{R}_{1}=4$-Fluorobenzene, $\mathrm{R}_{2}=$ Chlorine, $\mathrm{R}_{3}=$ dimethyl 26b ; $\mathrm{R}_{1}=4$ - Chlorobenzene , $\mathrm{R}_{2}=$ aminosulfamethoxazole, $\mathrm{R}_{3}=$ methyl

Fig. 10 Chemical structure and SAR studies of thiopyrimidine analogs 26(a-b)

A library of pyrimidine substituted with polymethoxy chalcones and thiazolopyrimidine for anticancer potential was reported. The activity was tested against 60 cell cancer line panel. 27 exhibited significant inhibition of tumor growth being highly efficient with cytotoxic and cytostatic attribute. SAR illustrated in Fig. 11 [30].

\section{2,3,4,6-Tetra substituted pyrimidine}

In a report, novel substituted pyrimidines and triazolopyrimidines were evaluated for antiproliferative activity against PC3, HCT116, MCF-7, and RPE1 cancer cell lines. It was discovered that $28\left(\mathrm{IC}_{50}=66 \pm 6 \mu \mathrm{m}\right)$ had the best potential against the RPE1 cell line. From the SAR studies, it was concluded that triazolpyrimidine glucosides/xylosides were found to be less active than substituted pyrimidine glycosides (Fig. 12) [31].
Pyrimidine fused with heterocyclic rings Pyrazole-pyrimidine derivatives

The heterocyclic moieties pyrazole and pyrimidines constitute two pharmacophores, which have potent antitumor activity. Various isomeric forms of pyrazolopyrimidine are known to possess excellent anticancer activity depending on the position of both the rings namely pyrazolo[1,5-a]pyrimidines, pyrazolo[3,4-d]pyrimidines, and pyrazolo $[4,3-d]$ pyrimidines.

\section{Pyrazolo [1, 5-a]pyrimidines}

In a recent report, some novel fused pyrazolopyrimidine derivatives were studied for anticancer activity as well as COX-2 inhibition against a 60 cancer cell line panel. Compound 29 was potent in case of both the studies. It was selective towards COX due to the presence of 5-amino-1-oxo-substituted-pyrazole-4-

The presence of polymethoxylated chalcones in a pyrimidine2-one ring gives good cytotoxic activity.<smiles>COc1cc(-c2nc([S-])[nH]c(=O)c2C#N)ccc1OCc1ccc(I)cc1I</smiles>
- - - - - - - - - - - - - - - - - -

Conversion pyrimidine moiety into thiazolopyrimidine gives the compound a wide range of activity.

Fig. 11 Chemical structure and SAR studies of pyrimidines substituted with poly-methoxy chalcones compound 27 


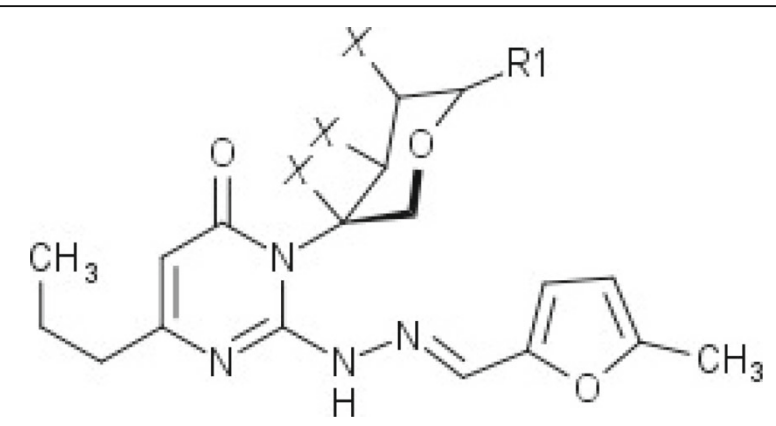

28; $\mathrm{R}_{1}=\mathrm{H}, \mathrm{X}=\mathrm{OAc}$

Fig. 12 Chemical structure of 2,3,4,6-tetra substituted pyrimidine derivatives

carbonitrile moiety [32]. Pyrazolo [1,5-a] pyrimidine derivatives which were tested for cytotoxicity by the MTT assay against cancer cell lines PC-3, HCT116, and HepG-2. 30a $\left(\mathrm{IC}_{50}=67.27 \pm 3.8 \mu \mathrm{M} / \mathrm{mL}\right)$ and 30b $\left(\mathrm{IC}_{50}\right.$ $=58.44 \pm 3.8 \mu \mathrm{M} / \mathrm{mL}$ ) demonstrated the best activity against HCT116 and PC-3 cell lines. SAR studies revealed that the order of antitumor activity was 4 methyl phenyl> 4 chloro phenyl> phenyl derivative against the cell lines and chlorine atom at 2 position was more active than 3 and 4 positions [33]. In another study by the same group, antitumor activities of pyrazolo [1, 5-a] pyrimidines was screened against HepG-2 and MCF-7 using MTT assay. 31a $\left(\mathrm{IC}_{50}=63.2 \pm 5.9 \mu \mathrm{g} / \mathrm{mL}\right)$ was reported have the best potential against MCF-7 carcinoma cells and 31b $\left(\mathrm{IC}_{50}=70.3 \pm 4.1 \mu \mathrm{g} / \mathrm{mL}\right)$ against HepG2 carcinoma cells. SAR suggested that substitutions with bulky groups like methoxy and bromo gave significant antitumor activity (Fig. 13) [34]. A new series of diamide substituted pyrazolo [1,5-a] pyrimidine derivatives were reported. 32(a-c) were active against $\mathrm{HeLa}$ cell lines where $\mathrm{IC}_{50}$ value of each was less than $10 \mu \mathrm{M}$ better than the marketed drug cisplatin. MTT assay was conducted to evaluate the cytotoxicity of the compounds. SAR discussed in Fig. 14 [35].

Chalcone-linked pyrazolo [1, 5-a] pyrimidines were reported as potential anticancer agents. $33\left(\mathrm{IC}_{50}=2.6 \mu \mathrm{M}\right)$ was most potent against the MDA-MB231 cancer cell line as screened by MTT assay. The compound caused increase in the expression of apoptosis-inducing proteins like p53, p21, and Bax, and decreased proapoptotic proteins like Bcl-2 and procaspase-9, while stopping the cell cycle at sub G1 phase. The activity was mainly due to $\mathrm{C}$ 5 substitution phenylprop-2-en-1-one and C-7 phenyl ring [36].

The antiproliferative activity of the pyrazolo [1, 5-a] pyrimidine derivatives bearing nitrogen mustard moiety were tested for antitumor activity against cell lines A549, SH-SY5Y, HepG2, MCF-7, and DU145 via MTT assay. 34 inhibited the cell growth at the G1 phase of the cell cycle by inducing apoptosis in all the five cancer cell lines with the $\mathrm{IC}_{50}$ range $=0.2$ to $8.3 \mu \mathrm{M}$. The compound was tested against human HepG2, HCC tumor xenograft in nude mice, and gave better potency than positive control drug sorafenib and cyclophosphamide also being less toxic to normal human cells. N-mustard pharmacophore at C-7 and other substituent at C-5 of the pyrrazolo-pyrimidine derivatives exhibited potent in vitro cytotoxicity but when $\mathrm{N}$-mustard pharmacophore is attached at $\mathrm{C}-5$ and various aniline moieties at C-7 the compound formed is found to be ineffective [37]. In a consecutive study a regioselective synthesis of pyrazolo [1, 5-a] pyrimidine derivatives was conducted in presence of KHSO4(aq) assisted by ultrasound. The<smiles>Nc1[nH]cc2[nH]c(=O)n3c4ccccc4nc3c12</smiles><smiles>[R1]NC(=O)c1c(Nc2ccc(OC)cc2)nn2c([R4])c([R3])c([R4])nc12</smiles>

30a; $\mathrm{R}_{1}=4-\mathrm{CH}_{3}-\mathrm{C}_{6} \mathrm{H}_{4}$, $\mathrm{R}_{2}=\mathrm{NH}_{2}, \mathrm{R}_{3}=\mathrm{CN}, \mathrm{R}_{4}=$ $\mathrm{Cl}$

30b; $\mathrm{R}_{1}=\mathrm{C}_{6} \mathrm{H}_{5}$,

$$
\mathrm{R}_{2}=\mathrm{OH}, \mathrm{R}_{3}=\mathrm{H}, \mathrm{R}_{4}=\mathrm{OH}
$$<smiles>[R]Nc1nn2c(Br)ccnc2c1C(N)=O</smiles>

$31 \mathrm{a} ; \mathrm{R}=\mathrm{C}_{6} \mathrm{H}_{5} ; \mathrm{R}_{1}=4-\mathrm{Cl}-\mathrm{C}_{6} \mathrm{H}_{4}$ 31b; $\mathrm{R}=4-\mathrm{CH}_{3} \mathrm{C}_{6} \mathrm{H}_{5} ; \mathrm{R}_{1}=4-$ Br- $\mathrm{C}_{6} \mathrm{H}_{4}$

Fig. 13 Chemical structures of pyrazolo [1, 5-a] pyrimidines 


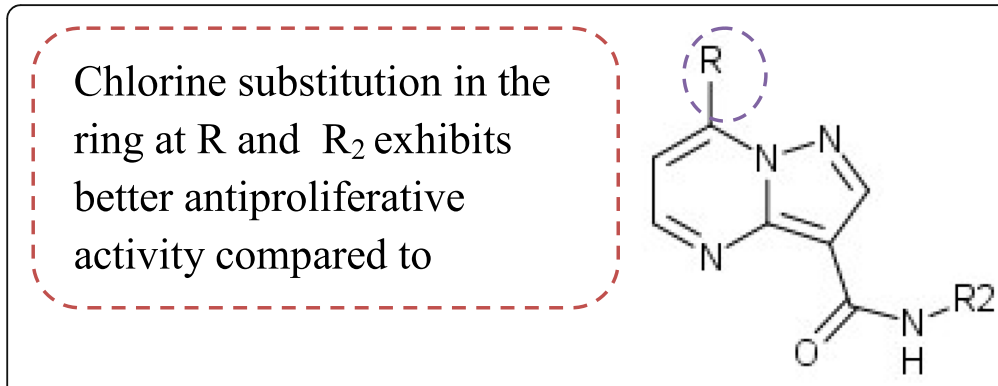

Halogen atoms in either of benzene ring at $\mathrm{R}$ and $\mathrm{R}_{2}$ enhances activity

\section{2a: $\mathrm{R}=\mathrm{o}-3$,4-dichloro-N-phenylbenzamide $\mathrm{R}_{2}=1$-chloro-2-ethylbenzene \\ 32b : $\mathrm{R}=\mathrm{p}-2,4,6$-Trichloro-N-phenylbenzene $\mathrm{R}_{2}=\mathrm{p}$-fluorotoluene \\ 32c: $\mathrm{R}=\mathrm{p}$ - 3,4-dichloro-N-phenylbenzamide $\mathrm{R}_{2}=\mathrm{p}$-fluorotoluene}

Fig. 14 Chemical structures and SAR studies of diamide substituted pyrazolo [1,5-a] pyrimidine

metabolically viable cells cleave the MTT to purple forzman at $570 \mathrm{nM}$ and results showed that compound 35 highly reduced the metabolism of MTT (Fig. 15) [38].

In vitro cytotoxicity of pyrazolo [1,5-a] pyrimidine against cell lines HCT-116, A549, HepG2, and MCF-7 was reported. 36a and 36b have the best cytotoxicity and cancer cell growth inhibitory properties compared to the standard drug DOX. Order of activity in substituted pyrazolo [1,5-a] pyrimidines was phenyl groups $>$ 4-chlorophenyl >4-methylphenyl group [39]. Moreover, some novel pyrazolo [1,5-a]pyrimidines were reported as the inhibitors of CDK9 which is often linked to cancer. The study used PIK-75 as a positive control and found out that the synthesized compound 37 ( $\mathrm{IC}_{50}$ $=203->1000 \mathrm{nM}$ ) is a better lead compound compared to PIK-75 due to lack of structural liabilities. The compound was also effective against FLT3 and MV4; 11 $\left(\mathrm{IC}_{50}=0.177\right.$ and $219 \mu \mathrm{M}$ respectively) cancer cell lines (Fig. 16) [40].

The synthesis of 2-aminobenzothizole conjugate linked with pyrazole [1,5-a] pyrimidines were tested for antitumor activity against cell lines namely A549, DU145, MCF-7, ACHN, and HeLa via MTT assay. 38a $\left(\mathrm{IC}_{50}\right.$ range $\left.=1.94-3.46 \mu \mathrm{M}\right)$ and $38 \mathrm{~b}\left(\mathrm{IC}_{50}\right.$ range $=$ 2.01-7.07 $\mu \mathrm{M}$ ) showed the best activity. Apoptosis was induced in caspase-3-dependent manner along with the arrest of cell cycle at G2/M and lowering of CDK1expression. SAR analysis suggests that substitution on the phenyl ring of aminobenzothiazole group does not show any promising effect on the activity whereas substitution on the 7-phenyl ring of pyrazolo [1,5-a]pyrimidine group is significant for the activity [41]. Interestingly, pim kinase inhibitors in the form of novel pyrazolo [1,5-a]pyrimidines were reported and it was concluded that compound 39 is a potential lead with low picomolar potency on the three isoforms of pim kinase. This particular enzyme is a significant target for cancer therapeutics but is hard to inhibit due to high affinity for ATP [42]. Novel 3-phenylpyrazolopyrimidine-1,2,3-triazole conjugates were studied for Src kinase inhibition and anticancer activity against SK-Ov-3, MDA-MB231, and HT-29 cell lines. 40a and 40c inhibited the enzyme with the<smiles></smiles>

33

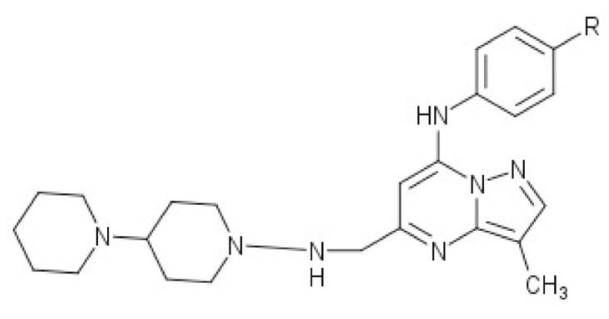

$34 ; \mathrm{R}=\mathrm{N}\left(\mathrm{CH}_{2} \mathrm{CH}_{2} \mathrm{Cl}\right)_{2}$<smiles>COc1ccc(-c2cc3nccc(-c4ccccn4)n3n2)cc1</smiles>

35

Fig. 15 Chemical structures of pyrazolo [1,5-a] pyrimidines 
<smiles>[R]NC(=O)c1c(Nc2ccc(OC)cc2)nn2c(O)cc(C)nc12</smiles>

36a; $\mathrm{R}=\mathrm{C}_{6} \mathrm{H}_{5}$ 36b; $\mathrm{R}=4 \mathrm{Cl}-\mathrm{C}_{6} \mathrm{H}_{5}$<smiles></smiles>

39<smiles>Cc1ccc(C#N)cc1O[N+](C)CCc1cnn2ccc(Cl)nc12</smiles>

37<smiles>[R]c1cn(CCn2nc(-c3ccccc3)c3c(N)ncnc32)nn1</smiles>

40a: $\mathrm{R}=$ hexane

40b: $\mathrm{R}=4 \mathrm{CH}_{3} \mathrm{OC}_{6} \mathrm{H}_{4}$<smiles></smiles>

38a; $\mathrm{R}=\mathrm{R}_{1}=\mathrm{R}_{2}=\mathrm{OCH}_{3} ; \mathrm{R}_{3}=\mathrm{R}_{4}=\mathrm{H}$ $\mathbf{3 8 b} ; \mathrm{R}=\mathrm{R}_{2}=\mathrm{R}_{3}=\mathrm{R}_{4}=\mathrm{H} ; \mathrm{R}_{1}=\mathrm{F}$<smiles>[R]C(=O)Cn1cc(Cn2nc(-c3ccccc3)c3c(N)ncnc32)nn1</smiles>

40c : $\mathrm{R}=$ propanol

Fig. 16 Chemical structures of pyrazolo [1, 5-a] pyrimidines

$\mathrm{IC}_{50}$ range $=5.6$ to $9.1 \mu \mathrm{M}$ and $40 \mathrm{~b}$ also inhibited the HT-29 cell line growth by $73 \%$. SAR suggests the presence of bulky group at N1 position is not tolerated (Fig. 16) [43].

\section{Pyrazolo [3,4-d] pyrimidine derivatives}

Novel pyrazolo $[3,4 \mathrm{~d}]$ pyrimidine derivatives were antagonists to human cancer cell malignancy and ROS induced apoptosis. A panel comprising of 60 cancer cell lines were used to test the compounds and it was found that 41 effected the cell line growth in dose dependent manner at $\mathrm{IC}_{50}=2 \mu \mathrm{M}$ and also generate ROS species [44]. Previously, a series of 4,6-disubstituted pyrazolo[3, 4- $d$ ] pyrimidine analogs inhibited the activity against the enzyme CDK2/cyclin E and Abl kinases as well as had anticancer attributes against MCF-7 and K-562 cell lines. 42 with $\mathrm{IC}_{50}=19.8 \mu \mathrm{M}$ (K-562) and $18.9 \mu \mathrm{M}$ (MCF-7) was the most efficacious and as per reports on $\mathrm{CHO}$ cell line it is non-toxic to normal human cells [45].

In a subsequent study, compound $\mathbf{4 3}$ showed the best anticancer activity against enzymes CDK2/cyclin E Abl kinases with significant activity against the K-562 and MCF-7 cell lines. Better CDK2 inhibition was observed with compounds with thiophenethyl group at C-6 and monosubstituted aniline at C-4 positions compared to thiopentane at C-6 and disubstituted aniline at C-4 position. Significant enzyme inhibitory activity was reported for compounds with 2-chloro, 3-nitro, and 4-methythio aniline at C-4 [46].

Synthesis as well as SAR studies of 6 '-fluorocyclopentenyl pyrimidine derivatives was carried out along with assay against six human cancer cell lines including HCT-116, SNU-638, A-549, PC-3, SK-Hep-1, and MDA-MB-231 via SRB assay. 44a $\left(\mathrm{IC}_{50}=1.10-2.17 \mu \mathrm{M}\right)$ and 44b $\left(\mathrm{IC}_{50}=2.14-15.3 \mu \mathrm{M}\right)$ exhibited good activity. The anticancer activity was attributed to arrest of sadenosylhomocysteine hydrolase which led to inhibition of histone methyltransferase. N6-amino group was essential for anticancer activity whereas deamination, introduction of bulky alkyl group or amino group at C2 position results loss of activity [47]. In simultaneous study, 4-aminopyrazolo [3,4-d] pyrimidines were reported as the potent inhibitors of both IGFIR/Src and as well as an anticancer agent with minimum toxicity to normal cells. 45 inhibited the kinase enzymes efficiently as well as induced apoptosis in the cancer cell lines MCF-7 and A549 with the $\mathrm{IC}_{50}$ range $=9.7$ to $15 \mu \mathrm{M}$. In vivo toxicity of the compound was evaluated on xenograft tumors and mutant Kras-driven lung tumorigenesis [48].

Pyrazolo [3,4-d] pyrimidines were reported as transmembrane RET inhibitors. 46 inhibited the RET phosphorylation and downstream signaling in BaF3/CCDC6RET cells being a potent RET inhibitor in the various biochemical assays conducted. It had an $\mathrm{IC}_{50}=61 \mathrm{nM}$ 
which makes it 6-folds more potent than the second best compound which was moderately efficacious against BaF3/CCDC6-RET cells with $\mathrm{IC}_{50}=433 \mathrm{nM}$ in the cellular assays. Flexible side chain on the isoxazoline moiety like hydroxymethyl turned out to be most potent RET kinase inhibitor. Extending the carbon chain, capping the free hydroxyl group or addition of esteric substituent/alkyl substituents bearing a terminal pyrrolyl/morpholinyl moieties led to decrease in activity [49]. In a parallel study, in vivo and in vitro anticancer activity of pyrazolo[3,4-d]pyrimidines, $\mathbf{4 7}(\mathbf{a}-\mathbf{b})$ were reported in the form of prodrug. The compounds were evaluated against U-87 cancer cell line (in vitro), against Src and Abl kinase enzyme and also in vivo [50].

A series of novel $\mathrm{N}-4$ substituted benzylidene acetohydrazide pyrazolo[3,4-d] pyrimidine was assessed for in vitro cytotoxicity against MCF-7, A549, and HT-29 cell lines. The compounds exhibited potent antitumor activity with 48 being the most potent. Molecular docking studies against the EGFR-TK revealed the compound was most effective inhibitor with docking score of -28.8 $\mathrm{Kcal} / \mathrm{mol}$ [51]. Pyrazolo[3,4-d] pyrimidine-3-carbonitriles were evaluated for activity against Hep 2 cancer cell line using MTT assay. Compound 49a $\left(\mathrm{IC}_{50}=36.9 \mu \mathrm{M}\right)$ and compound $49 \mathrm{~b}\left(\mathrm{IC}_{50}=21.3 \mu \mathrm{M}\right)$ were found to be more active compared to the standard anticancer drug 5-FU $\left(\mathrm{IC}_{50}=41.5 \mu \mathrm{M}\right)$. The presence of NH-C-S moiety and $\mathrm{N}$-tosyl group in the pyrazolo-pyrimidine may be accounted for the activity [52].

Pyrazolo[3,4-d]pyrimidinones derivatives $\mathbf{5 0}$ (a-e) containing 1,2,3-triazole displayed good anticancer activity against the MCF-7 and HCT-116 cell lines using MTT assay. At the concentration of $100 \mu \mathrm{M}$, the inhibition percent of the cancer cell growth by these compounds is of the range $43-75 \%$ with tamoxifen as positive control. The major anticancer activity in this series of compounds is observed due to the presence of triazole group linked to the pyrazolo-pyrimidine ring through the methylene spacer linker [53]. Previously, novel pyrazolo[3,4-d]pyrimidine derivatives having anticancer potential were evaluated using MTT assay. 51 was tested against a panel of various cancer cell lines had the best potential against the $\mathrm{A} 549$ cells with $\mathrm{IC}_{50}=$ $2.49 \mu \mathrm{M}$ which is comparatively better than the positive control DOX [54].

In a study on cross-docking simulation of pyrazolo-[3, 4-d]pyrimidine on Bcr-Abl T315l mutant, 52a and 52b exhibited the best activity. 4-Bromo atom in paraposition of the $\mathrm{N} 1$ side chain of phenyl ring was responsible for interaction with the T315l mutant. The antitumor activity was tested in vivo using a mouse model xenograft [55]. Interestingly, a series of pyrazolo[3,4-d] pyrimidine was formed via substituting different polar moieties in $\mathrm{C} 4$ and $\mathrm{C}-6$ positions of a promising anti leukemia lead. The compounds exhibited Src/Abl inhibitory activity and potent antiproliferative activity in leukemia cell lines (KU-812, MEG-01, and K-562). 53a and 53b showed good in vitro ADME properties as well as active in hypoxic leukemia cells [56].

Pyrazolo [3,4-d] pyrimidines with benzylidene hydrazinyl group were tested for their cytotoxic activity against MCF-7 cell line. 1-Phenyl substituted derivatives exhibited better activity compared to 1-(4-methoxyphenyl) derivatives compound $54\left(\mathrm{IC}_{50}=7.5 \mathrm{nM}\right)$ was the most potent [57]. One pot synthesis of pyrazolo [3, 4-d] pyrimidine derivatives along with their antiproliferative activity was reported. $\mathbf{5 5}(\mathbf{a}-\mathbf{d})$ showed the most potency due to the presence of $\mathrm{p}-\mathrm{Me}-\mathrm{Ph}, \mathrm{p}-\mathrm{Cl}-\mathrm{Ph}$, or $\mathrm{p}-\mathrm{OMe}-\mathrm{Ph}$ group at $\mathrm{C}-3$ position and phenyl or 2-quinolinyl groups at N-1 [58]. The green synthesis of pyrazolo [3, 4]-pyrimidine-thiones was carried out and $56(\mathbf{a}-\mathbf{b})$ were most potent with $\mathrm{IC}_{50}=66$ and $35 \mathrm{mg} / \mathrm{ml}$ against EAC cell lines (Fig. 17) [59]. Compound 57 was reported to be most active among the series of substituted pyrazolo [3, 4-d] pyrimidines with the in vitro evaluation against MCF-7 cancer cell lines. The level of hydrogen peroxide and activity of superoxide dismutase were noticed to increase significantly whereas catalase activity and glutathione peroxidase levels were lowered. SAR is illustrated in Fig. 18 [60].

\section{Pyrazolo [4,3-d]-pyrimidine}

Pyrazolo [4, 3-d] pyrimidines with substitutions at 3, 5, 7 positions were reported as the inhibitors of CDK and also tested for in vivo and in vitro anticancer activity. $\mathbf{5 8}$ was the most potent, inhibited $\mathrm{CDK} 2,5$ and $9\left(\mathrm{IC}_{50}=\right.$ $0.002 \mu \mathrm{M})$ as well as exhibits both activities, and was better than the positive control CR8. When tested against 60 panels of cancer cancer cell lines, apoptosis was induced due to activation of caspases, dephosphorylation of CDK substrates, downregulation of XIAP, and MCL-1 and cleavage of PARP-1. In vivo activity was evaluated against various xenograft models. It was suggested that the activity was due to the modification of 2aminoethylthio group [61]. Previously, pyrazolo [4,3-d] pyrimidine a bioisoester of roscovitine was evaluated for the dual property of both CDK inhibition and antiproliferative activity. 59 was the bioisoster responsible for both the activities of CDK inhibition being the primary one. The anticancer activity of the compound was tested against a cancer cell line panel of $60\left(\mathrm{IC}_{50}\right.$ range $=3.6 \pm$ 0.3 to $11 \pm 1.8 \mu \mathrm{M})$ [62].

In vitro activity of substituted pyrazolo[4,3-d]-pyrimidine derivatives were reported against MCF-7, HT-29, and HepG2 tumor cell lines. Tetrazole ring fused to pyrazole $[4,3-d]$-pyrimidine $\mathbf{6 0}$ was most potent against all the cell lines with $\mathrm{IC}_{50}$ range $=0.13 \pm 0.03$ to $0.36 \pm$ $0.04 \mu \mathrm{mol} / \mathrm{L}$ respectively. The presence of tetrazole 

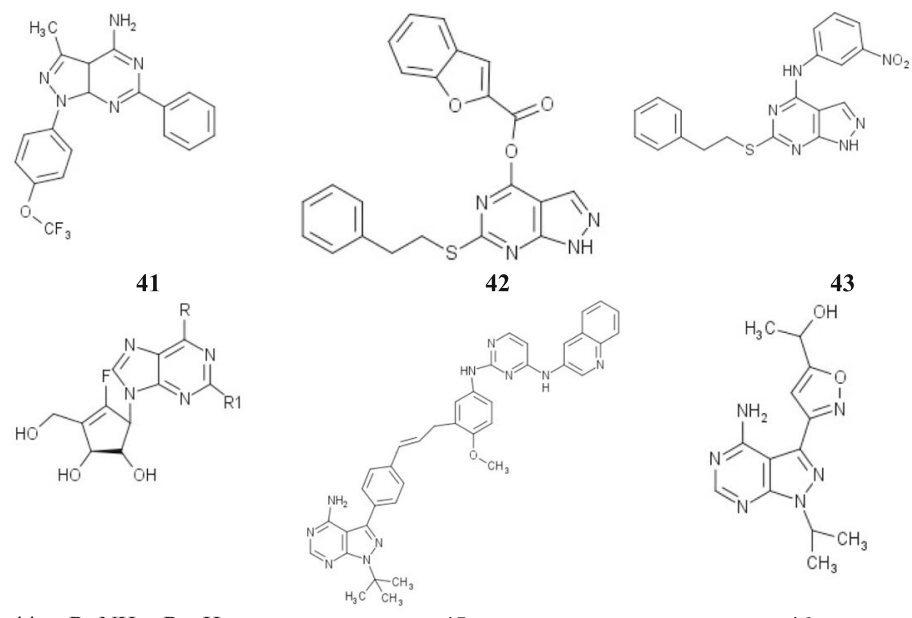

44a : $\mathrm{R}=\mathrm{NH}_{2}, \mathrm{R}_{1}=\mathrm{H}$

45

46

44b: $\mathrm{R}=\mathrm{NHMe}, \mathrm{R}_{1}=\mathrm{H}$

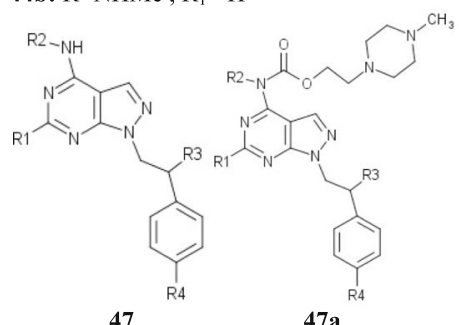

$\mathrm{R}_{1}=\mathrm{S}-\mathrm{CH}_{2} \mathrm{CH}_{2} 4$-morpholine, $\mathrm{R}_{2}=\mathrm{C} 6 \mathrm{H} 4 \mathrm{mBr}, \mathrm{R}_{3}=\mathrm{Cl}$,

$\mathrm{R}_{4}=\mathrm{H}$

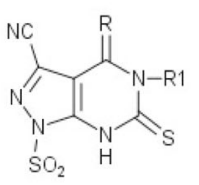

$49 \mathrm{a} ; \mathrm{R}=\mathrm{NH} \mathrm{R} \mathrm{R}_{1}=\mathrm{H}$

$49 \mathrm{~b} ; \mathrm{R}=\mathrm{S}, \mathrm{R}_{1}=\mathrm{Ph}$

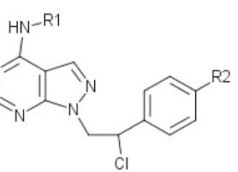

52a : $\mathrm{R}_{1}=\mathrm{CH}_{2} \mathrm{C}_{6} \mathrm{H}_{4} \mathrm{Br}, \mathrm{R}_{2}=\mathrm{Br}$ 52b ; $\mathrm{R}_{1}=\mathrm{C}_{6} \mathrm{H}_{5}, \mathrm{R}_{2}=\mathrm{Br}$<smiles>Fc1ccc(/C=N/Nc2ncnc3c2cnn3-c2ccc(F)cc2)cc1</smiles>

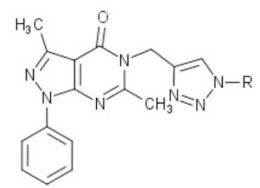

$\mathbf{5 0} ; \mathrm{R}=\mathrm{Ph}$

50b; $\mathrm{R}=4-\mathrm{CH}_{3}$

50c; $\mathrm{R}=4-\mathrm{OCH}_{3}$,

50d; $\mathrm{R}=4-\mathrm{Cl}-\mathrm{Ph}$

50e; $\mathrm{R}=1$ - napathyl

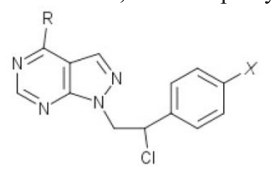

53a $; \mathrm{R}=\mathrm{NH}-4$-picolyl $\mathrm{X}=\mathrm{Cl}$<smiles>[R]c1nn([X])c2ncncc12</smiles>

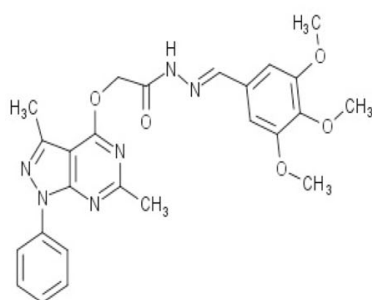

48

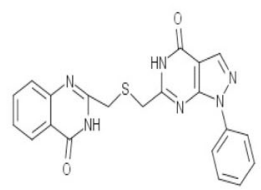

51

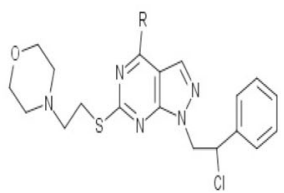

53b; $\mathrm{R}=\mathrm{NHCH}_{2} \mathrm{C}_{6} \mathrm{H}_{5}$

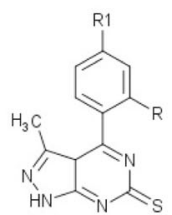

55a; $\mathrm{R}=2$-Quinolinyl, $\mathrm{X}=\mathrm{p}-\mathrm{Me}-\mathrm{ph} \quad$ 56a $: \mathrm{R}=2-\mathrm{NO}_{2}$,

55b; $\mathrm{R}=\mathrm{Ph}$ p-ClPh, $\mathrm{X}=\mathrm{p}-\mathrm{Cl}-\mathrm{Ph} \quad \mathrm{R}_{1}=\mathrm{H}$

55c; $\mathrm{R}=2$-Quinolinyl, $\mathrm{X}=\mathrm{p}-\mathrm{Cl}-\mathrm{ph} \quad$ 56b: $\mathrm{R}=2-\mathrm{OH}$,

55d; $R=2$-Quinolinyl, $X=$ p-OMe-ph $\quad \mathrm{R}_{1}=4-\mathrm{OH}$

Fig. 17 Chemical structures of pyrazolo [3, 4-d] pyrimidines 


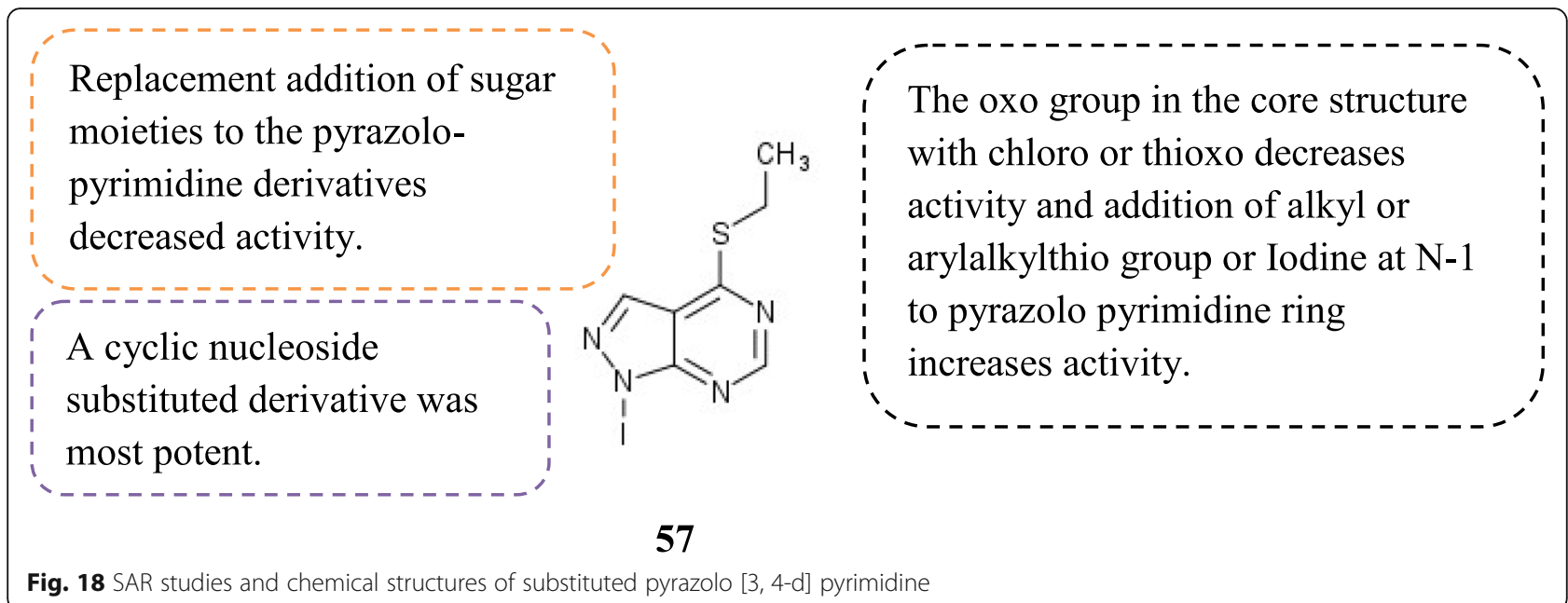

moiety fused to the pyrazolo-pyrimidine ring and also the nature of the substituted groups at the aryl ringlinked carbohydrazide with the pyrazole unit led to increased cytotoxic activity [63]. In a simultaneous study, a series of 5-substituted 3-isopropyl-7-[4-(2-pyridyl) benzyl] amino-1(2) H-pyrazolo [4,3-d] pyrimidine derivatives were reported and it was concluded that compound 61 was the most potent inhibitor of both CDK2 $\left(\mathrm{IC}_{50}=21 \mathrm{n} \mathrm{M}\right)$ and CDK5 $\left(\mathrm{IC}_{50}=35 \mathrm{n} \mathrm{M}\right)$. The activity was mainly due to the presence of hydroxyalkylamines at the 5 position of the pyrazolo-pyrimidine ring. The cell cycle was arrested at $\mathrm{S}$ and $\mathrm{G} 2 / \mathrm{M}$ phase which resulted in induction of apoptosis [64].

In study selective inhibitors of CDK2, CDK5, and aurora A kinase with in vitro anti-angiogenic activity were reported. 62 was the most potent in the series and was known to inhibit all the three kinase enzymes as well as cause the downregulation of cyclins $\mathrm{A}$ and $\mathrm{B}$, the dephosphorylation of histone H3 at Ser10, and the induction of mitochondrial apoptosis in the HCT-116 cancer cell line. It also reduced cell migration in human endothelial cells. The anti-angiogenic property of the<smiles>CCCc1nn(C)c2c(=O)[nH]c(-c3cc(OC)cc(OC)c3)nc12</smiles> 
compound is linked to CDK5 inhibition [65]. The microwave assisted synthesis of 1H-pyrazolo [4,3-d] pyrimidin-7 $(6 \mathrm{H})$-ones and their anticancer activity were reported. The compounds were tested against HeLa, CAKI-I, PC-3, MiaPaca-2, and A549 human cancer cell lines by MTT assay. 63 was the most potent as it exhibits anticancer activity against all cell lines and the $\mathrm{IC}_{50}$ range $=14$ to $38 \mu \mathrm{M}$, with apoptosis mechanism along with mTOR inhibition at nM potency (Fig. 19) [66].

\section{Pyrrolo-pyrimidine derivatives}

$7 \mathrm{H}$-pyrrolo [2,3-d] pyrimidine derivatives were reported as potential FAK inhibitors. 64 suppressed the FAK enzymatic action at $\mathrm{IC}_{50}=5.4 \mathrm{nM}$ and inhibited the MDA-MB231 and A549 cancer cell lines with the $\mathrm{IC}_{50}$ range $=3.20 \pm 0.41$ to $17.41 \pm 1.3 \mu \mathrm{M}$ respectively. The compound had activity against a panel of 26 kinases and was less cytotoxic against the HK2 cell line. It led to induction of apoptosis and suppression of migration in lung cancer cell line in a dose dependently. The SAR studies are illustrated in Fig. 20 [67].

Previously, some Src tyrosine kinase family selective novel pyrrolo [2, 3-d] pyrimidine derivatives were reported. The inhibitory activity was tested against the Fyn, Lyn, Hck, and c-Src members of the Src kinase family. 65 was known to show the most potent activity Fyn, Lyn, and c-Src though it was non selective and not show activity against the Hck. PP2 and CGP77675 were used as positive control [68]. A novel series of pyrrolopyrimidine and pyrrolo-pyridine compounds bearing pyridazinone moiety were studied as c-Met kinase inhibitors, evaluated for in vitro and in silico molecular docking activity against the A549, HepG2, PC-3, and MCF-7 cancer cell lines. 66a was more active than $\mathbf{6 6} \mathrm{b}$ showed excellent activity against the cell lines with the $\mathrm{IC}_{50}$ $(\mu \mathrm{M})$ range $3.62 \pm 1.24$ to $9.61 \pm 0.95$ and $2.73 \pm 0.98$ to $3.77 \pm 1.24$ respectively. The compound induced apoptosis in HePG2 cell line. The compounds were screened against 4 tyrosine kinase (Slp-3, VEGRF-2, c-Kit, and EGFR). EWG on the aryl group in the pyridazinone moiety makes the compound increasingly active. The pyridine derivatives containing pyridazinone moiety are better than the pyrimidine moieties comparatively and, thus, a pyridine derivative was selected as c-Met kinase inhibitor [69].

A series of novel sulfonamide bearing pyrrolopyrimidine derivatives were screened against the MCF-7 cancer cell line. 67a and $67 \mathbf{b}\left(\mathrm{IC}_{50}=8.30\right.$ and $\left.8.39 \mu \mathrm{M}\right)$ exhibited comparable activity to the positive control DOX. For the study of the mechanism of action, a molecular docking study on the compounds was conducted for the Src kinase enzyme and it was suggested that the inhibition of this enzyme is the reason for the anticancer potential of the compounds (Fig. 21) [70].

\section{Triazole pyrimidine derivatives \\ Triazolo [1, 5-a] pyrimidines}

Recently $[1,2,4]$ triazolo[1,5-a ]pyrimidine derivatives were screened for in vitro antiproliferative activities against HeLa, HCT116, and A549, via MTT assay. Compound 68 efficiently inhibited the growth of A549 and HeLa, cell lines with $\mathrm{IC}_{50}=1.02$ and $0.75 \mu \mathrm{M}$ respectively. HeLa cells arrested in G2/M phase of cell cycle and had a detrimental effect on the cell morphology and microtubule networks. The SAR is depicted in Fig. 22 [71].

In a study based on the cytotoxicity of 1, 2, 3-triazoles and 1, 2, 4-triazolo fused with $[1,5-\mathrm{a}]$ pyrimidines in MCF-7 cancer cell line. 69 showed better activities compared to other compounds in the series. VEGF and its receptor VEGFR are essential for the neovasculature; it is also associated with the progression of various malignancies which make this a significant target for the cancer treatment. The effect of the compounds on the MCF-7 cancer cell line was tested with the help of immunoblotting assay. 1, 2, 3-triazoles cause the inhibition of VEGFR1 giving a lead to evaluate the effect of EFT of

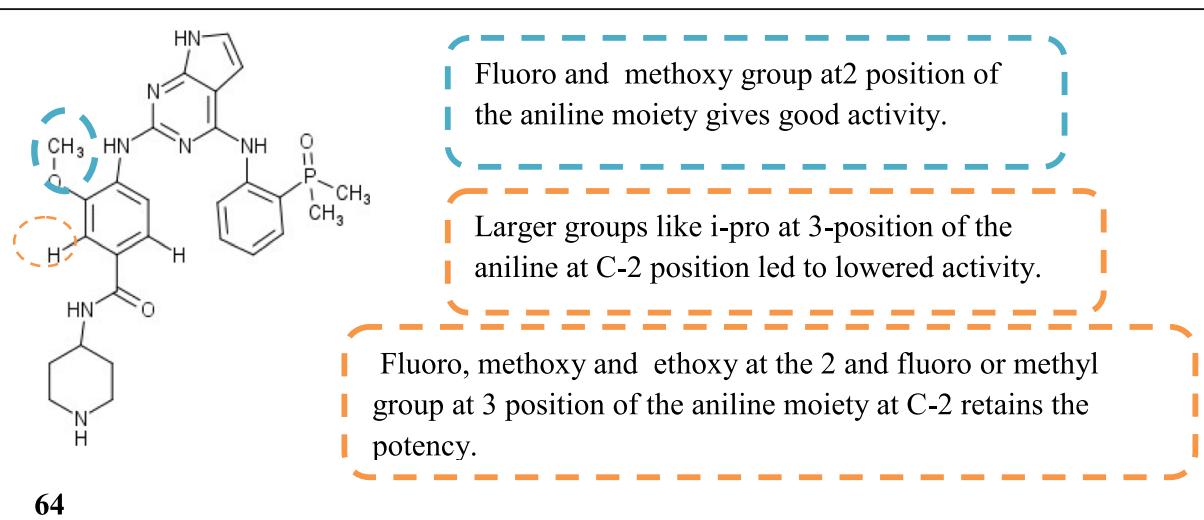

Fig. 20 SAR studies and chemical structures of 7H-pyrrolo [2, 3-d] pyrimidine derivative as FAK enzyme inhibitors 


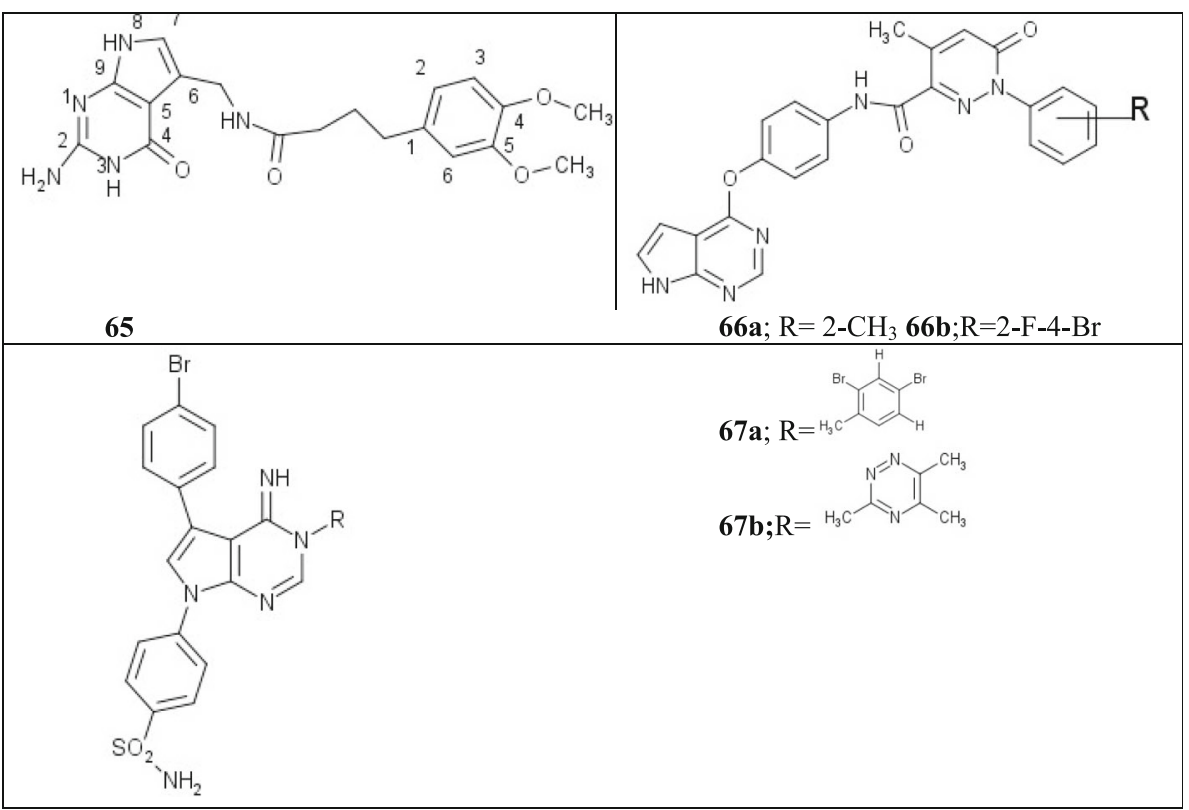

Fig. 21 Chemical structure of pyrrolo-pyrimidine derivatives

VEGFR1. Results concluded that the compounds are non-toxic to normal human cells and EFT downregulates the expression of VEGFR1 thus, imparting activity by targeting VEGFR1 in breast cancer cells [72]. In a report $[1,2,4]$ triazolo fused with $[1,5$-a]pyrimidines linked with monomeric and dimeric steroids the compounds elucidated activity against a panel of six solid tumor cell lines. The results determined $\mathbf{7 0 a}-\mathbf{b}$ as the most potent against T-47D and WiDr cells, better than positive control cisplatin [73].

Novel steroidal[17,16-d][1,2,4]triazolo [1,5-a]pyrimidines were determined as antitumor agents against PC3, MCF-7, and EC9706 cancer cell lines. 71(a-c) were found to show great activity in the evaluation by the cytotoxic assay. The presence of $\mathrm{p}$-isopropyl and $\mathrm{o}-$ phenoxy on the phenyl rings at $R$ position increased the anticancer activity whereas the phenyl rings at $\mathrm{R}$ when replaced by heteroaromatic rings did not change the activity (Fig. 23) [74].

\section{Triazolo $[4,5-d]$ pyrimidine}

LSD1 is known to play a significant role in lysine methylation and over expression of the LSD1 lead to progression of certain human malignant tumor. In the year 2017, [1-3] triazolo [4, 5-d] pyrimidine derivatives were reported for their LSD1 inhibition properties. 72 with the $\mathrm{IC}_{50}=0.564 \mu \mathrm{M}$ inhibited the LSD1 very efficiently. The compound demonstrated selectivity for LSD1 over monoamine oxidase by acting as a reversible inhibitor. When the MGC-803 cells were treated with compound 72, the activity of LSD1 was instantly inhibited along with the migration of the cells to a great extent [75]. Previously worked on a series of hydrazone bearing $[1,2$, 3] triazolo[4,5-d]pyrimidine derivatives and evaluated<smiles>COc1cc(C2=NC3N=C(C)C(C(C)=O)C(c4ccc5c(N)cccc5c4)N3N2)cc(OC)c1OC</smiles>

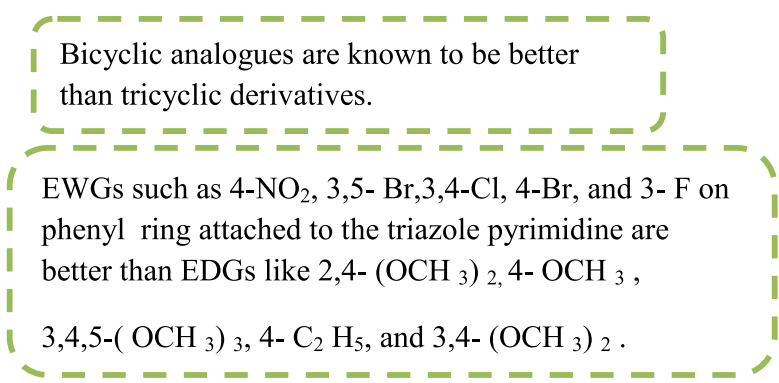


<smiles>CCOc1cc(F)ccc1-c1ncn2ncnc2n1</smiles>

69<smiles>[R7]c1c2c(nc3ncnn13)[C@@]1(C)CCC3C(CC[C@@H]4NC(=O)CC[C@]34C)C1C2</smiles><smiles>[Z11][Z11](=[R])C</smiles><smiles>[R]C#Cc1cccc(Oc2ccccc2)c1</smiles>

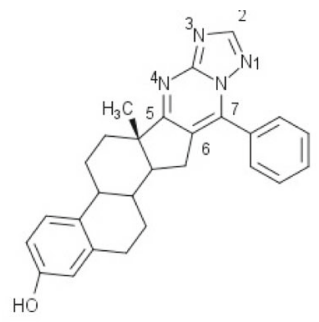

$70 a$

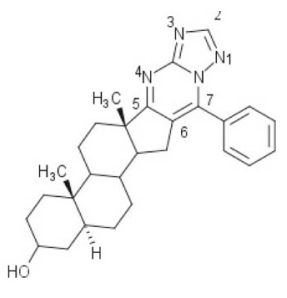

70b

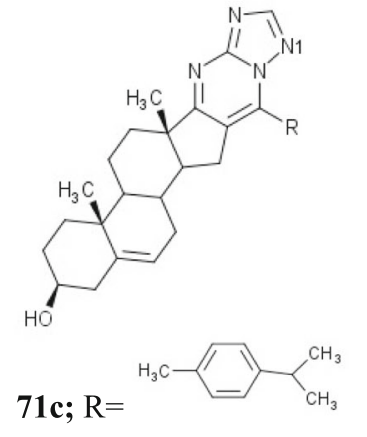

Fig. 23 Chemical structure of triazolo pyrimidines

their activity against different human cancer cell lines via MTT assay. Compound 73 showed the best efficiency by being selective towards normal cell line and the cancer cell line. The compound had an $\mathrm{IC}_{50}=0.87$ $\mu \mathrm{M}$ against the MGC-803 cell line and $\mathrm{IC}_{50}=56.17 \mu \mathrm{M}$ for the GES1. On further analysis, it was concluded that the compound induces apoptosis by attacking the mitochondrial pathway by decreasing the mitochondrial membrane potential, upregulation of the expression of Bax, Bak, activation of caspase- $9 / 3$, and p-53, and downregulation of that of Mcl-1 and Bcl2. The compound also inhibited formation of MGC803 cells at concentration of $0.8 \mu \mathrm{M}$ (Fig. 24) [76].

\section{Other triazolo pyrimidine derivatives}

A group of novel pyrimidine-2, 4-dione-1,2,3-triazole and furo[2,3-d]pyrimidine2-one-1,2,3-triazole hybrids derivatives were reported. The evaluation was carried out with a vast range of cell line and 5-FU was used as positive control. 74 exhibited the best cytostatic activity against HepG2 and HeLa cells with an $\mathrm{IC}_{50}=$ $2.67 \mu \mathrm{M}$ and $6.51 \mu \mathrm{M}$ respectively. In terms of mechanism, cytostatic effect was attributed to its property of inhibition of Wee-1 kinase and finishing of sphingolipid signaling mediated by acid sphingosine kinase 1 and ceramidase. The compound was nonmitochondrial toxic agent (Fig. 24) [77].

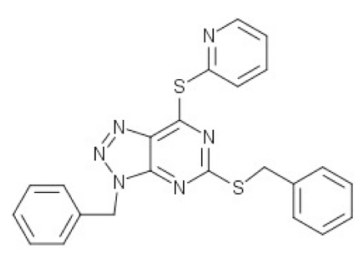

72

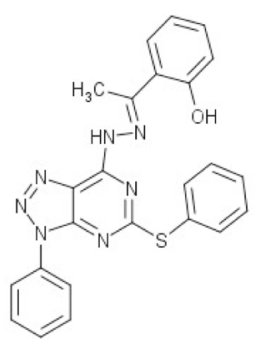

73<smiles>O=C1C=c2c(oc(Cc3ccccc3)c3c(cn2Cc2cnnn2Cc2ccccc2)C(c2ccccc2)C#C3)=N1</smiles>

74

Fig. 24 Chemical structure of Triazolo and other triazolo pyrimidine derivatives 


\section{Imidazolo pyrimidine derivatives}

Recently, antiproliferative activity of N-9- and N-7-1,2,3 triazole analogs of 2,6-di-substituted purines was reported. They were tested against HCT-1, THP-1, IMR-32, and A549 cancer cell lines. 75 was the most potent against the THP-1 and A-549 cell lines with the $\mathrm{IC}_{50}=0.08$ and 0.4 $\mu \mathrm{M}$ respectively. The activity was mainly due to $\mathrm{C} 6$ position substitution with amines like aminoethnol and benzyl amine, and $\mathrm{C} 2$ position was substituted with cyclic secondary amines like piperidine and pyrolidine [78]. Earlier, the anticancer activity of newly synthesized imidazo[1,2-a]pyrimidine mannich bases was studied. In a series of 29 compounds $7 \mathbf{6}(\mathbf{a}-\mathbf{c})$ were found to be the most potent giving similar activity to DOX. The compounds were evaluated against the human lung, pancreatic, cervical, and breast adenocarcinoma cell lines. The compound 76a inhibited the growth of all the four cancer cell lines. The two series of compounds were evaluated by the SRB assay. From the SAR analysis, it was concluded that the main activity of the compounds is due to the $\mathrm{C}-2$ and $\mathrm{C}-3$ substitutions [79].

(RS)-9-(2,3-dihydro-1,4-benzoxaheteroin-2-ylmethyl)$9 \mathrm{H}$-purines were reported for anticancer activity and tested against the MCF-7 cancer cell line. $77(\mathbf{a}-\mathbf{c})$ are known to show the best activity with the $\mathrm{IC}_{50}$ range 2.75 \pm 0.03 to $7.64 \pm 0.03 \mu \mathrm{M}$. Compound 77b showed 3.3fold higher activity than their bioisosters. The compounds inhibited eIF2 $\alpha$ phosphorylation and induced apoptosis in the p53-independent manner (Fig. 25) [80].

\section{Pyrido pyrimidine derivatives}

\section{Pyrido [1,2-a]pyrimidine derivatives}

For the 3-carboxamide derivatives of pyrido[1,2-a]pyrimidine, the compounds were tested against DU145,
A549, SiHa, and MCF-7 using 5-FU as positive control. $78 \mathbf{b}$ and $78 \mathbf{a}$ showed relatively higher activity with $\mathrm{IC}_{50}$ $=3.6 \pm 0.11$ and $3.2 \pm 0.12 \mu \mathrm{g} / \mathrm{mL}$ against A549 respectively. In the SAR, it was established that thien-2-yl group in place of phenyl group at 6th position of the compounds showed better activity (Fig. 26) [81].

\section{Pyrido[2,3-b]pyrimidine derivatives}

Novel pyrido $\left[3^{\prime}, 2^{\prime}: 4,5\right]$ furo[3,2-d]pyrimidines were reported. The compounds were screened against Hela, neuro-2a, Colo 205, and A549 tumor cell lines using the MTT assay. 79a and 79b were the most potent with $\mathrm{IC}_{50}$ range $=5.8$ to $3.6 \mu \mathrm{M}$. Pyrimidinone ring had better activity than furo $[2,3-b]$ pyridine ring system. Nitrogen substitution on $\mathrm{N} 3$ resulted in marginal reduction the cytotoxicity (Fig. 26) [82].

\section{Pyrido[2,3-d]pyrimidine derivatives}

In a parallel study HepG-2 and HCT-116 cancer cell lines were screened by novel pyrido[2,3-d]pyrimidine derivatives and $\mathbf{8 0}(\mathbf{a}-\mathbf{d})$ were found to be most active (Fig. 26) [83]. Pyrido[2,3-d] [1,2,4]triazolo[4,3-a]pyrimidine derivatives and pyrido [2,3-d]pyrimidines were evaluated against two cancer cell lines, namely $\mathrm{PC}-3$ and A549. $81\left(\mathrm{IC}_{50}=0.36 \mu \mathrm{M}\right)$ showed activity against both the cell lines with 5-FU (positive control) but was more sensitive on cell line PC-3. The cell cycle was arrested at G1 phase and induction of apoptosis in PC-3 cell line was due to caspase-3 dependent pathway. SAR is illustrated in Fig. 27 [84].

Pyrido[2,3-d]pyrimidine derivatives were screened for their cytotoxic properties against $\mathrm{PC}-3$ cell line using the MTT assay. $82\left(\mathrm{IC}_{50}=7.0 \mu \mathrm{M}\right)$ exhibited strong activity

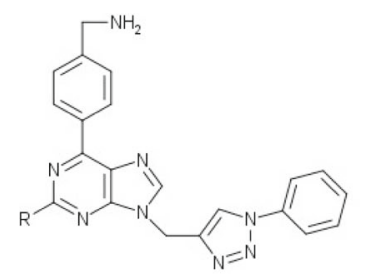

75; $\mathrm{R}=$ Pyrolidine
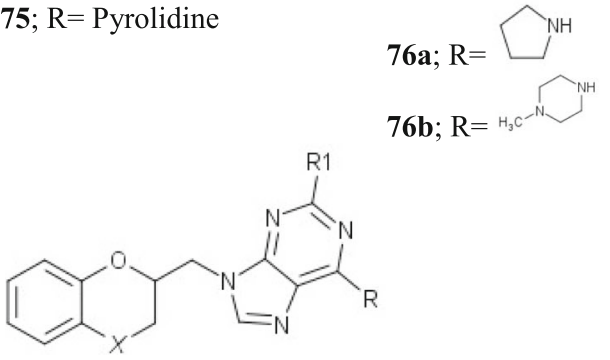

77a $; \mathrm{R}=\mathrm{Br}, \mathrm{R}_{1}=\mathrm{H}, \mathrm{X}=\mathrm{S}$

$77 \mathbf{b} ; \mathrm{R}=\mathrm{Cl}, \mathrm{R}_{1}=\mathrm{Cl}, \mathrm{X}=\mathrm{S}$

77c; $\mathrm{R}=\mathrm{Br}, \mathrm{R}_{1}=\mathrm{H}, \mathrm{X}=\mathrm{O}$
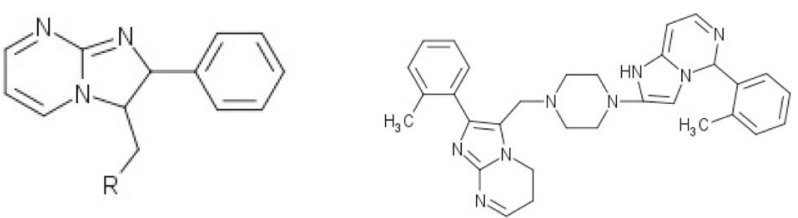

$76 c$

Fig. 25 Chemical structure of imidazolo-pyrimidine derivatives 
<smiles>[R1]NNC(=O)c1cnc2cc(C(F)(F)F)cc([R])n2c1=O</smiles>

78a; $\mathrm{R}=$ Thien-2-yl,R1= Ethyl

$\mathbf{7 8 b}$; $\mathrm{R}=$ Thien-2-yl, $\mathrm{R}_{1}=$ Propyl<smiles>COc1ccc(-c2cc(-c3ccco3)c3c(Cl)ncnc3n2)cc1</smiles>

80c<smiles>COc1ccc(-c2cc(-c3ccco3)c3c(N)ncnc3n2)cc1</smiles>

$80 a$<smiles>COc1ccc(-c2cc(-c3ccco3)c3c(NN)ncnc3n2)cc1</smiles><smiles>CCCC(=O)NNC(=O)c1oc2nc(C(F)(F)F)ccc2c1NC(=O)CCCl</smiles>

79b<smiles>COc1ccc(-c2cc(-c3ccco3)c3c(N)nc(C)nc3n2)cc1</smiles>

80b

Fig. $\mathbf{2 6}$ Chemical structures of pyrido pyrimidine derivatives

compared to the positive controls due to the ability of increasing capase-3 levels leading to dose dependent cell cycle arrest. The screening reveals that the pyridopyrimidine nucleus is better than the corresponding quinazoline, mainly when the substitutions in 2 and 4 positions are different. Substitutions $\mathrm{SCH}_{3}$ or $\mathrm{SeCH}_{3}$ located at paraposition of the aryl moiety improved the activity [85]. Simultaneously, the 1,8-naphthyridines substituted isosters of 2,4,5,7-tetrasubstituted pyrido[2,3-d]pyrimidines were reported. The cytotoxic activity was investigated against MCF7 cancer cell line where 83a and 83b $\left(\mathrm{IC}_{50}=7.70\right.$ and $7.54 \mu \mathrm{M}$ respectively) were efficacious compared to DOX $\left(\mathrm{IC}_{50}=8.48 \mu \mathrm{M}\right)$, the positive control [86].

A study of potential in vitro cytotoxic activity of selenium and sulfur derivatives of pyrido[2,3-d]pyrimidine were screened against four cancer cell lines, HTB-54,
HT-29, MCF-7, and CCRF-CEM. 84 (a-c) exhibited cytotoxic effects in all cell lines tested where 84c was selectively potent against MCF-7 with cisplatin and etoposide as positive control. It was concluded that the cell death was induced without affecting cell cycle phases. The derivatives with a SeH group in the 4th and 2nd positions usually have better activity than the analogs with selenoalkyl group [87]. In later researches, cancer cell lines HeLa, A549, PANC 1, and MDA MB-231 at $<10$ $\mu \mathrm{M}$ concentration were used to test the anticancer activity of new triazole/isoxazole functionalized 7-(trifluoromethyl) pyrido [2,3-d]pyrimidine derivatives. 85a against PANC1 and 85b against A549 had the best activity better compared to positive control nocodazole. The high anticancer activity of the compound was due to the presence of ethyl chain at C-2 position and the long alkyl/ perfluoroalkyl chain at $\mathrm{R}$ on triazole ring. Many 


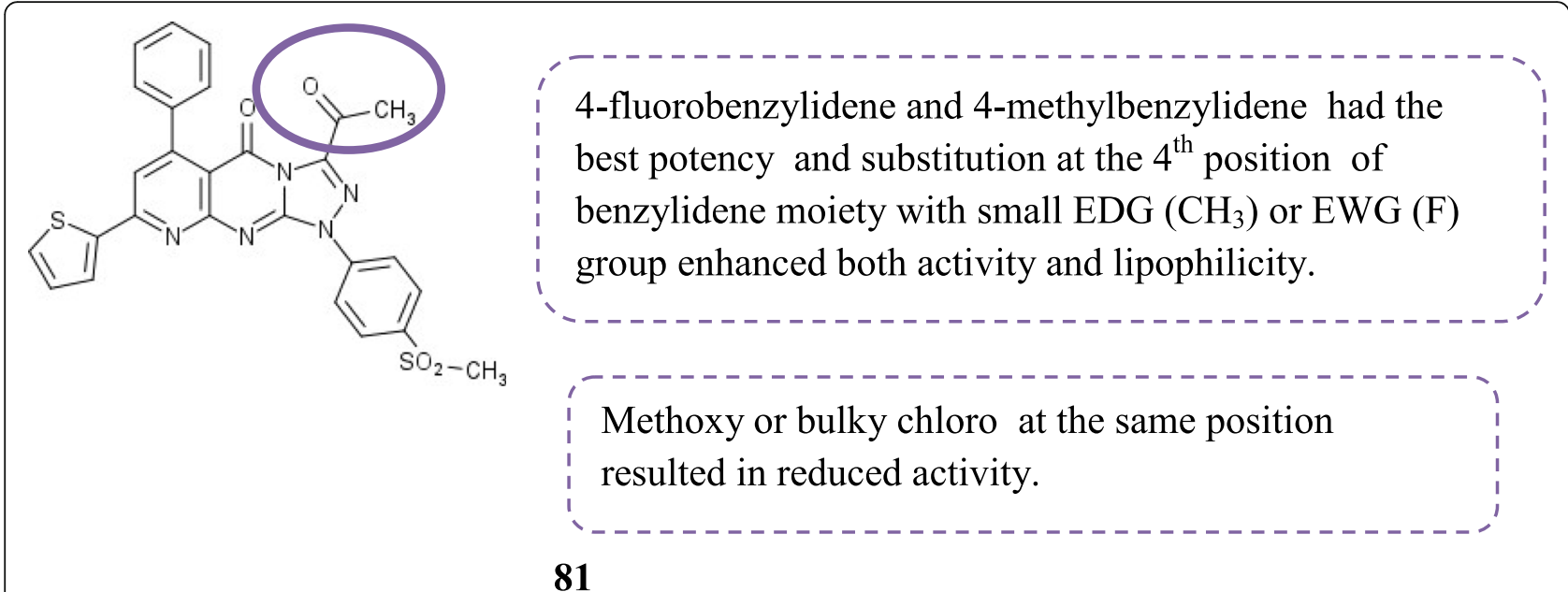

Fig. 27 SAR studies and chemical structures of pyrido[2,3-d] [1,2,4]triazolo[4,3-a]pyrimidine derivatives and pyrido [2,3-d]pyrimidine

structures showed activity regardless of the substitutions on the $\mathrm{C}-2$ position or the triazole ring [88].

Interestingly, some pyrido[2,3-d]pyrimidine derivatives inhibiting EGFR were reported for elucidating potency against A549, MCF-7, BT-474, MDA-MB-231, and SKBR-3. 86a and 86b were found to have potent inhibition activity against the EGFR tyrosine kinase with the $\mathrm{IC}_{50}=$ $2.97 \mathrm{nM}$ and $3.58 \mathrm{nM}$ respectively and also showed good anti-proliferative activity against the SK-BR-3 cells $\mathrm{IC}_{50}$ $=3.10(\mathbf{8 6 a})$ and $5.87 \mu \mathrm{M}(\mathbf{8 6 \mathbf { b }})$. Similar binding pattern to the EGFR was observed standard drug gefitinib (Fig. 28) [89].

Compounds 87 (a-b), pyrido[2,3-d]pyrimidine derivatives with alkyl triazole, were reported for exhibiting anticancer activity with $\mathrm{IC}_{50}$ range $=8.16 \pm 0.68$ to $19.25 \pm$ 1.46 and $15.01 \pm 1.54$ to $6.20 \pm 0.68 \mu \mathrm{g} / \mathrm{ml}$ respectively. They were active against cancer cell lines THP-1, U937, and COLO 205 as screened by MTT assay. Activity of the abovementioned compounds was better compared to positive control etoposide, against U937 cell lines. SAR is illustrated in Fig. 29 [90].

\section{Pyrido[3,4-d]pyrimidines}

Potential anticancer agents in the form of new pyrido [3, 4-d]pyrimidine derivatives were evaluated against the panel of 60 cancer cell lines resulting to be selective towards the renal and breast cancer. 88a had good activity and selectivity towards both breast and renal cancer cell lines. 88b had selective for breast cancer cell line due to the expression of certain kind of kinase enzymes namely, PDGFR, ErbB-1, HER2/Neu (ErbB-2, over expressed in 15-20\% of breast cancer), EGFR, and VEGFR [91].

\section{Other pyrido pyrimidine derivatives}

Pyrido[20,30:3,4] pyrazolo[1,5-a]pyrimidine derivatives were tested against cancer cell lines MDA-MB-231
(HTB-26), HeLa (CCL-2), Hep G2 (HB-8065), PC-3 (CRL-1435), and normal HUVEC (CRL-1730). 89(a-c) displayed prominent antitumor activity with the $\mathrm{IC}_{50}$ $(\mu \mathrm{M})$ range $=5.22$ to $93.2 \pm 0.14$ with 5 -FU was used as control. 89a and 89c inhibited topoisomerase I (TopI) activity, which was comparable to camptothecin thus making it a significant target for the anticancer activity. The compounds were also tested on the normal cell line HUVEC and had an $\mathrm{IC}_{50}$ more than $80 \mu \mathrm{M}$ making it non-toxic for the normal cells [92]. Subsequently, substituted pyrido pyrimidines derivatives were evaluated for against cancer cell lines, PC-3, HepG-2, MCF-7, HCT-116, and A-549. 90 showed the best activity against the cell lines with the $\mathrm{IC}_{50}=0.5$ to $7 \mu \mathrm{M}$ with DOX as positive control. 90 also exhibited promising activity against three kinases CDK4/cyclin D1, EGFR, and PDGFR $\beta$, at two different concentrations of $100 \mu \mathrm{M}$ and $50 \mu \mathrm{M}$ at a mono measurement. In further assessment of the compound, molecular docking studies were conducted to check the binding of the compound with EGFR and CDK4/cyclin D1 kinases. Overall, the potency of the compound was credited to remarkable kinase inhibitory activity (Fig. 30) [93].

\section{Thieno pyrimidine derivatives Thieno[2,3-d]pyrimidines}

Novel 2,3-disubstituted-4-oxo-5,6,7,8-tetrahydrobenzo $[4,5]$ thieno[2,3-d]pyrimidines were studied against breast and liver cancer cell lines with DOX a positive control. 91 showed the best activity in the series with the $\mathrm{IC}_{50}=$ $0.19 \mu \mathrm{M}$ (breast cancer cell line). The SAR is illustrated in Fig. 31 [94]. Some novel thieno[2,3-d]pyrimidines with aminophosphonate were studied anticancer activity against the HepG2, MGC-803, and EC109 by MTT assay. 92 was the most potent with the inhibitory percent of 91.2 and 94.4 at $50 \mu \mathrm{g} / \mathrm{ml}$ concentration 


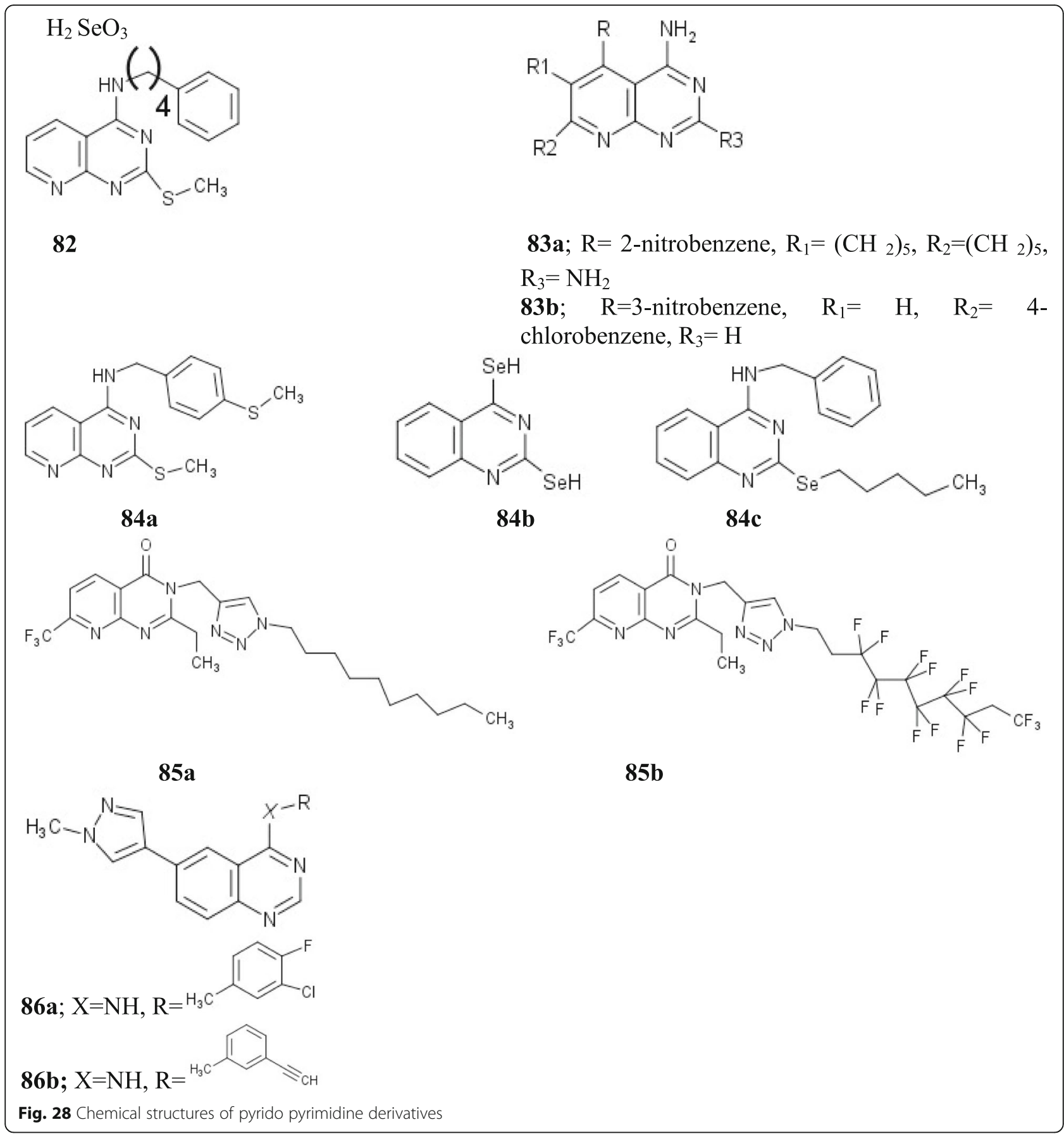

specifically against the HepG2 and MGC-803 respectively. SAR is depicted in Fig. 32 [95].

Antitumor activity of some 3-ethyl-2-mercaptothieno [2,3-d]pyrimidin-4(3H)-ones was reported and screened against HT-29, MDA-MB231, HeLa, and HepG2 as well as Lep-3. 93a was active against the HepG2 cell line with the $\left(\mathrm{IC}_{50}=0.99 \mu \mathrm{M}\right)$, 93b was potent against the HeLa cell line $\left(\mathrm{IC}_{50}=0.83 \mu \mathrm{M}\right)$, and 93c with the $\left(\mathrm{IC}_{50}=\right.$ $0.001 \mu \mathrm{M})$ against the HT-29 cell lines. In the theinopyrimidine derivative linked to the thiadiazole, activity was due to the presence of oxygen 4th position of the theinopyrimidine ring [96]. A series of thieno [2,3-d]pyrimidine derivatives were reported to initiate apoptosis and EGFR/HER2 arrest. Targeting a tyrosine kinase-related entity makes a drug important in cancer treatment regime. The compounds were tested in vitro for the inhibition of the EGFR and those which passed the test were further evaluated for the mutant EGFR and HER2 kinase inhibition. MCF-7, HCT-116, A431, and HepG2 cell lines were used to screen compound $94\left(\mathrm{IC}_{50}\right.$ range = 


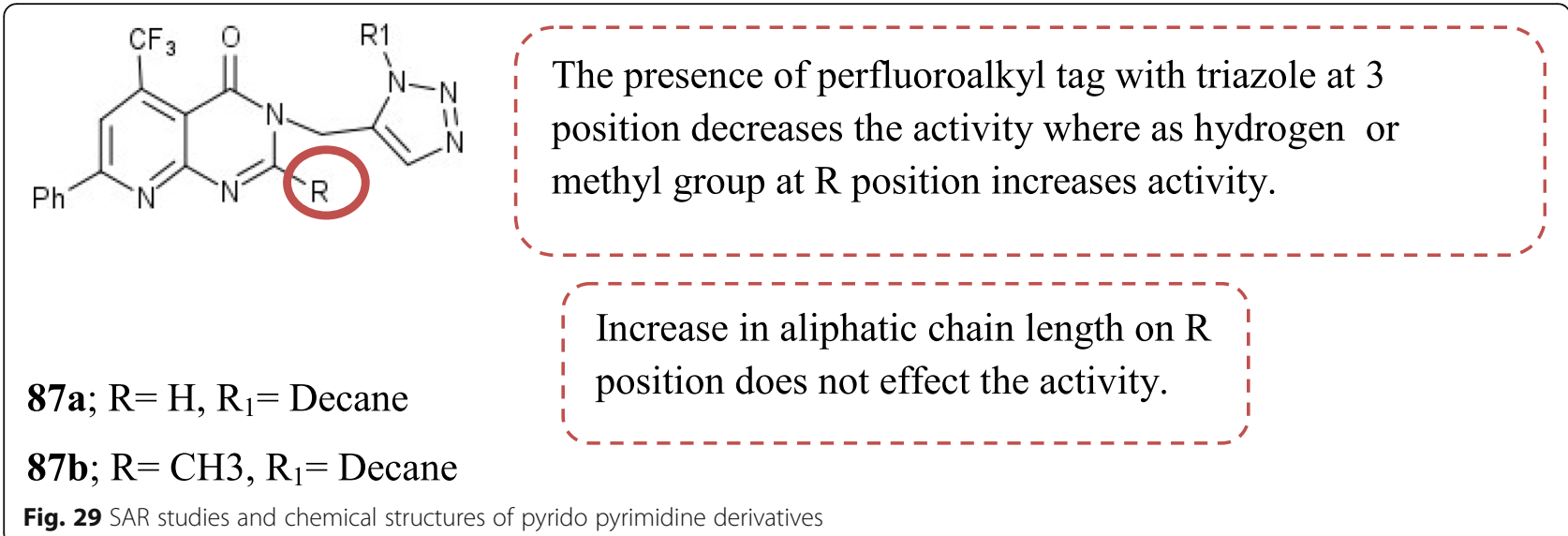

$7.5 \pm 0.32$ to $16.06 \pm 0.02 \mu \mathrm{M})$ compared to erlotinib as reference. The compound arrested the cell cycle at G2/ $\mathrm{M}$ phase and induced apoptosis in the breast cancer cell lines; it also had a binding affinity for EGFR as concluded in the docking studies [97].

Recently, anticancer evaluation of the thieno [2,3d]pyrimidine derivatives in the inhibition of the enzyme toposiomerase II was reported. 95(a-d) were designed and tested against the HepG2 and MCF-7 cell lines giving the $\mathrm{IC}_{50}$ range $=4-10 \mu \mathrm{M}$. Compounds with higher
$\mathrm{IC}_{50}=>60 \mu \mathrm{M}$ showed selectivity towards the cell lines. The major mechanism of action in the whole process was that the active compounds upregulated the expression of p-53, downregulated the expression of caspase-3, led to the cell cycle arrest, and further apoptosis leading to cancer cell destruction. These compounds increased the p-53 expression by 3-4-folds compared to the 2folds of DOX [98].

Thieno[2,3-d] pyrimidine derivatives were active against 60 human cancer cell line panel by the primary<smiles>[R]c1nc(N)nc2c([R])nccc12</smiles>

88a; $\mathrm{R}=\mathrm{OMe}, \mathrm{R}_{1}=\mathrm{NH}-\mathrm{ph}-4$

$\mathrm{Cl}$

$\mathbf{8 8 b} ; \mathrm{R}=\mathrm{OMe}, \mathrm{R}_{1}=-\mathrm{Ph}-3-\mathrm{F}$<smiles>[R]c1cc([R1])n2nc3nc(C(F)(F)F)c(C(=O)OCC)cc3c2n1</smiles><smiles>Cc1ccc(-c2cc(-c3ccc(Cl)cc3)nc3nc(-n4[nH]c(C)cc4=O)[nH]c(=O)c23)cc1</smiles>

89a; $\mathrm{R}=\mathrm{CF}_{3}, \mathrm{R}_{1}=\mathrm{H}$, 90

89b; $\mathrm{R}=\mathrm{C}_{6} \mathrm{H}_{5} \mathrm{R}_{1}=\mathrm{C}_{4} \mathrm{H}_{4} \mathrm{~N}$,

89c; $\mathrm{R}=\mathrm{C}_{4} \mathrm{H}_{3} \mathrm{~S}$,

$\mathrm{R}_{1}=4-\mathrm{O} \mathrm{CF}_{3} \mathrm{C}_{6} \mathrm{H}_{5}$

Fig. 30 Chemical structures of pyrido pyrimidine derivatives 


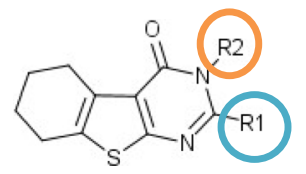

Trimethoxy group led to decreased activity compared to styryl moiety $\mathrm{R}_{1}$ at position

6-amino-9-methylacridin-3-yl, p- sulfamoylphenyl, 5-

nitrobenzothiazol-2-yl or benzothiazol-2-yl at $\mathrm{R}_{2}$ position exhibited

increased activity

91; $\mathrm{R}_{1}=$ styryl, $\mathrm{R}_{2}=6$-amino-9-methylacridin -3 -yl

Fig. 31 SAR studies and chemical structures of 2,3-disubstituted-4-oxo-5,6,7,8-tetrahydrobenzo [4,5]thieno[2,3-d]pyrimidines

anticancer assay as a result $\mathbf{9 6}$ was found to have the best activity. Although the compound 96 exhibited a wide spectrum of activity, it was not selective towards any particular group of human cancer cell lines [99].

Evaluation for in vitro antiproliferative activity of new thieno [2, 3-d] pyrimidine and thiophene derivatives was conducted and 97(a-e) were the best compounds, with the $\mathrm{IC}_{50}(\mu \mathrm{M})=4.30 \pm 0.3$ to $23.57 \pm 1.8$ when tested against five cancer cell lines namely, HepG-2, Hep-2, MCF-7, PC-3, and HeLa by the standard MTT assay. 97d was efficient than the positive control DOX. The abovementioned compounds were also tested for DNA binding and enzyme inhibition activity, the order of inhibition: DNA polymerase> thymidylate synthase >tyrosine kinase [100]. In a parallel study, some novel thieno [2, 3-d] pyrimidine derivatives were tested for antitumor activity against the human breast and cervical cancer cell line. 98b was highly active with the $\mathrm{IC}_{50}=18.87 \pm 0.2$ $\mu \mathrm{g} / \mathrm{ml}$, and the 98a was active against cervical cancer cell line with the $\mathrm{IC}_{50}=40 \pm 1.7 \mu \mathrm{g} / \mathrm{ml}$ both better than the positive control, Paclitaxel [101].

Recently, urea derivative based thieno $[2,3-d]$ pyrimidine-based were screened for in vitro antitumor activity against the tamoxifen sensitive and resistant breast cancer cell lines. 99 a sorafenib analog and a theinopyrimidine-based urea derivative inhibited VEGF R2 tyrosine kinase activity up to $65 \%$ and also showed anticancer activity against its parental MCF7 BC cells, LCC2 and TAM-resistant. The compound was also sensitive to the LCC2 due to the upregulation of key enzymes for apoptosis, LDH in media downregulated the mRNA expression of Ki-67, survivin, and Akt and reduced levels of ROS and glucose uptake led to cell death of proteins like caspases $8,9,3, \mathrm{p} 53, \mathrm{Bax} / \mathrm{Bcl}-2$ ratio [102]. Some novel thieno [2, 3-d] pyrimidines were evaluated in 2012 and compounds $100(\mathbf{a}-\mathbf{b})$ showed the best antitumor activity against the HCT-116 with the $\mathrm{IC}_{50}=$ 15.92 and $25.85 \mu \mathrm{M}$ and 19 to 2.26 times more efficacious than imatinib $\left(\mathrm{IC}_{50}=34.40 \mu \mathrm{M}\right)$. SAR suggested that $\mathrm{N}$-ethyl substitution imparted comparable activity to the positive control whereas $\mathrm{N}$-phenyl or $\mathrm{N}$ substituted phenyl gave moderate activity in case of thienopyrimidine derivatives (Fig. 33) [103].

Tetrahydrobenzo $[4,5]$ thieno $[2,3-\mathrm{d}]$ pyrimidine-4-yl)pyrolidine-2-carboxylic acid derivatives were studied for in vitro anticancer activity against MCF-7 and HCT-116. 101 (a-b) demonstrated decent activities against the MCF-7 in contrast to the standard positive control DOX. In the SAR studies, it was concluded that aniline derivatives show good anticancer activity, 101a being a 4-fluro aniline derivative showed the most potent activity. SAR is depicted in Fig. 34 [104].

A series of thieno [2, 3-d] pyrimidine derivatives were reported and evaluated for the in vitro activity against

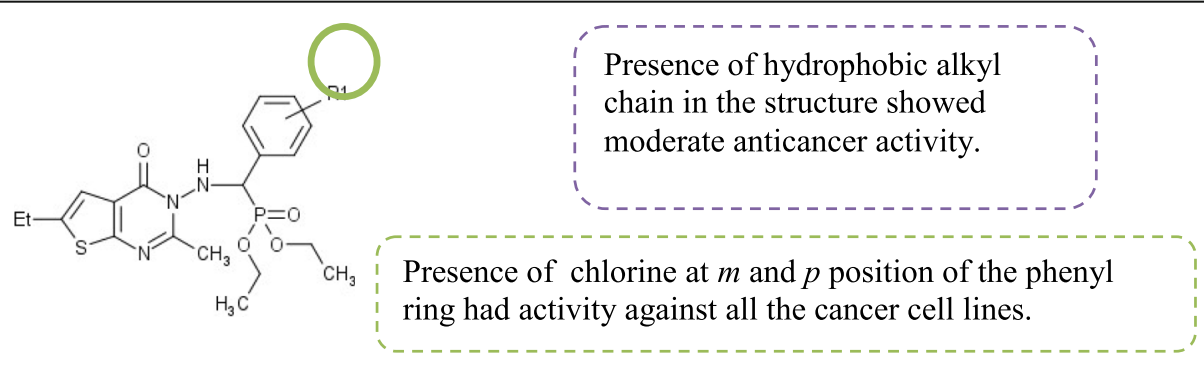

92; $\mathrm{R}_{1}=4-\mathrm{Cl}$

Fig. 32 SAR studies and chemical structures of thieno [2, 3-d] pyrimidines having a-aminophosphonate 
<smiles>[R]c1sc2nc(SCc3nnc(NCC)s3)n(CC)c(=O)c2c1[R]</smiles>

93a $; \mathrm{R}=\mathrm{CH}_{3} ; \mathrm{R}_{1}=\mathrm{CH}_{3}$ 93b; $\mathrm{R}=\mathrm{CH}_{3} ; \mathrm{R}_{1}=\mathrm{COOC}_{2} \mathrm{H}_{5}$ 93c; $\mathrm{R}=\mathrm{R}_{1}=\left(\mathrm{CH}_{2}\right)_{4}$

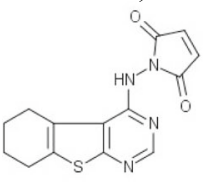

95a<smiles>Cc1c(C(N)=O)sc2nc(C)n(/N=c3\scc(-c4ccccc4)n3Cc3ccccc3)c(=O)c12</smiles>

96

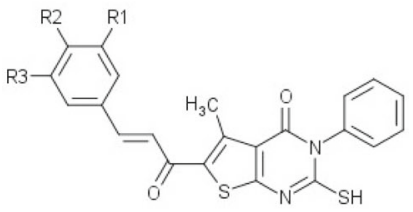

97d $; \mathrm{R}_{1}=\mathrm{H}, \mathrm{R}_{2}=\mathrm{CH}_{3}, \mathrm{R}_{3}=\mathrm{H}$

97e $; \mathrm{R}_{1}=\mathrm{O} \mathrm{CH}_{3} \mathrm{R}_{2}=\mathrm{O} \mathrm{CH}_{3}, \mathrm{R}_{3}=\mathrm{O} \mathrm{CH}_{3}$

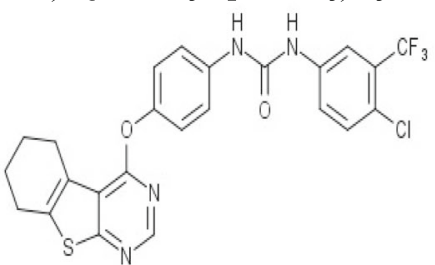

99

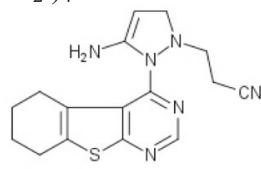

$95 b$

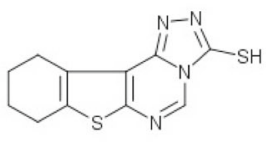

$95 c$

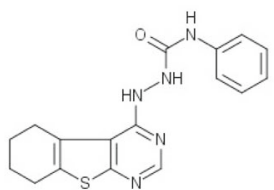

95d<smiles>[R]n1c(S)nc2sc(C(C)=O)c(C)c2c1=O</smiles>

97a; $\mathrm{R}=$ benzene

97b; $\mathrm{R}=\mathrm{p}$-Chlorobenzene

97c; $\mathrm{R}=$ Ethyl benzene<smiles>[R]c1sc2nc(N3CCOCC3)nc(-c3ccccc3)c2c1N</smiles>

98a $; \mathrm{R}=\mathrm{COPh}, \mathbf{9 8 b} ; \mathrm{R}=\mathrm{CONHPh}-4-\mathrm{Cl}$<smiles>Nc1ncnc2sc3c(c12)CCCCCC3</smiles>

$100 \mathrm{a}$

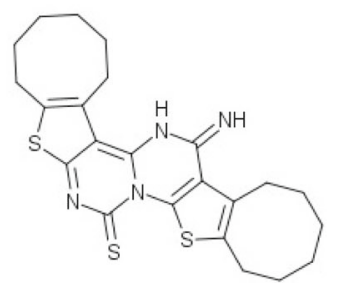

100b

Fig. 33 Chemical structures of thieno pyrimidine derivatives

the MCF-7 cancer cell line. 102(a-f) elucidated good oncogenic activity with the $\mathrm{IC}_{50}$ range $=37.78$ to 22.12 $\mu \mathrm{M}$. Compounds 102a, 102d, 102e, and 102f showed better activity than DOX with the $\mathrm{IC}_{50}=30.40 \mu \mathrm{M}$ and (102b and c) showed nearly same activity as the positive control. SAR study is summarized in Fig. 35 [105].

Amide containing thieno[2, 3-d] pyrimidines were studied for their growth inhibition effects in different cancer cell lines MDA-MB-453, MCF-7, DU-145, A549 HCT-116, HT-29, HCT-15, and BT-549. 103(a-c) were tested for growth inhibition and 103c exhibited selectivity towards MDAMB-453 and MCF-7 cell and arrested cell cycle at G0/G1 phase in MCF-7 cells. This potential was attributed to the presence of cinnamide moiety and trifluoromethyl group. 103(d-e) was selective towards A549 and MDA-MB-453cell lines, respectively, with ZSTK474 as positive control [106]. Previously, the varied substitution of groups at the $\mathrm{R}$ position of the thieno $[2$, 3-d] pyrimidine derivatives led to properties like c-Met and VEGFR-2 inhibition which is an important target 


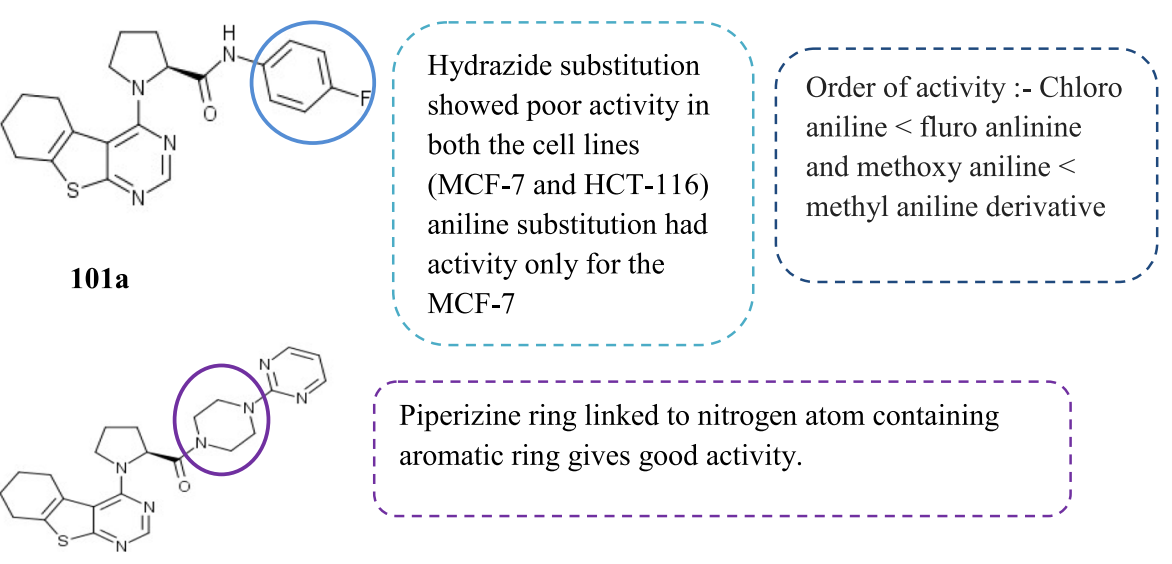

$101 \mathrm{~b}$

Fig. 34 SAR studies and chemical structures of new tetrahydrobenzo [4,5]thieno [2, 3-d] pyrimidine-4-yl)-pyrolidine-2-carboxylic acid derivatives

for cancer therapies. BaF3-TPR-Met cells were used to test 104(a-b), which elucidated nearly equivalent inhibition percent compared with the cabozantinib (positive control). 104a was most potent against HUVEC and BaF3-TPR-Met with $\mathrm{IC}_{50}=0.086 \mu \mathrm{M}$ and $0.051 \mu \mathrm{M}$, respectively, and displaying the most efficient inhibitory activity against VEGFR-2 and c-Met with $\mathrm{IC}_{50}=0.048$ $\mu \mathrm{M}$ and $0.025 \mu \mathrm{M}$ [107].

Recently, condensed thieno [2, 3-d] pyrimidines were evaluated for their cytotoxic potential against A431 and H9c2 cancer cell lines through MTT assay. Most of the synthesized compounds except 105 had $85 \%$ cell death in both rat and $\mathrm{H} 9 \mathrm{c} 2$ cell lines. The presence of ethyl, methyl, and ethyl-fused five-membered rings in the structure showed better activity in A431 than in H9c2 cells and in case of the six-membered structures, methyl-substituted cyclohexyl compounds inhibited
A431 cell growth, although dimethyl substituted thiophene derivatives displayed better activity in H9c2 cells. Nitromethyl, cyclohexyl, and dimethyl substitution lowered activity compared to chloro substitution fused with seven membered rings and the methyl-substituted structures had better potency than the aryl substituted structures [108].

Anticancer activity, apoptosis-inducing ability, and cell cycle profiling of hexahydrocyclooctathieno [2, 3-d] pyrimidines was reported using DOX as positive control. 106(a-b) were tested for antiproliferative activity against 56 cancer cell lines and 106b was potent against a broad range of cell lines. 106a and 106b led to the induction of S-phase and G2/M-cell cycle arrest in MCF7 and HCT116 cell lines with a significant increase in the pre$\mathrm{G}$ phase cell population in a time-dependent way; 106b also increased cleaved caspase- 3 as a marker of apoptosis

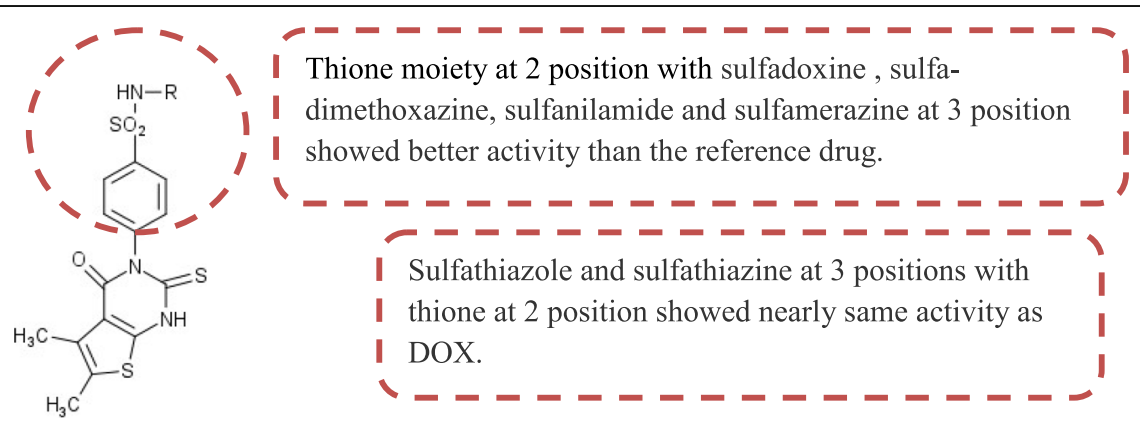

102

$\mathbf{a} ; \mathrm{R}=$ sulfanilamide, $\mathbf{b} ; \mathrm{R}=$ sulfathiazole, $\mathbf{c} ; \mathrm{R}=$ sulfadiazine, $\mathbf{d}=$ sulfamerazine, $\mathbf{e} ; \mathrm{R}=$ sulfadimethoxazine, $\mathbf{f} ; \mathrm{R}=$ sulfadoxine

Fig. 35 SAR studies and chemical structures of new tetrahydrobenzo [4,5]thieno [2, 3-d] pyrimidine-4-yl)-pyrolidine-2-carboxylic acid derivatives 
[109]. A series of new 2-pyridyl hexahydrocycloocta [4, 5]thieno [2, 3-d] pyrimidine derivatives were evaluated with DOX as positive control. $107(\mathbf{a}-\mathbf{e})$ manifested the most potent activity due to the substitution of 2-pyridyl group at $\mathrm{C}$-2, amino group at $\mathrm{C}-4$ increases activity, and chlorine group at $\mathrm{C}-4$ leading to an inactive compound and the bulkiness of the amino at $\mathrm{C}-4$ effects the activity [110].

\section{Thieno [3, 2-d] pyrimidine}

$\mathrm{N}$-substituted thieno [3, 2-d] pyrimidine and thiophene derivatives were studied for the antitumor activity and 108(a-b) had more potency than standard drug DOX in MTT assay against the cancer cell lines of liver, colon, and lung. According to the SAR the pyrrolo-pyrimidine moiety and triazolopyrimidine moiety at the C-3 position of the theinopyrimidine ring and EWG at the paraposition of the phenyl ring contributed to the high activity, on the contrary an EDG at the same position gives moderate activity [111]. Screening of antitumor activity of 4-morpholinothieno [3, 2-d]-pyrimidine derivatives bearing aryl methyl hydrazine moiety were reported. The activity was mainly due to heteroaryl methylene hydrazinyl moiety and various substitutions on the benzene ring when screened against H460, HT29, and MDA-MB-231 cell lines. 109 bearing 3,4-methylenedioxy phenyl group was most efficacious against all the three abovementioned cell lines with the $\mathrm{IC}_{50}=$ $0.003 \mu \mathrm{M}, 0.42 \mu \mathrm{M}$, and $0.74 \mu \mathrm{M}$ respectively with more selectivity towards lung cancer cell line and was 1.6- to 290-folds more active than GDC0941 [112].

Diaryl urea moiety containing thieno [3,2-d] pyrimidine derivatives were tested for their antitumor activity by MTT assay using sorafenib and GDC-0941 (positive control). 110 was tested against various tumor cell lines gave the most potent activity against the MDA-MB-231, MKN-45, HT-29, and H460 and cell lines with the $\mathrm{IC}_{50}$ $=0.23 \mu \mathrm{M}, 0.18 \mu \mathrm{M}, 0.058 \mu \mathrm{M}$, and $0.081 \mu \mathrm{M}$ respectively. The SAR of the study concluded that the compounds with the mono halogen group on the phenyl ring were more efficient than the one's with methyl group or double groups and presence of chlorine atom at the 6,7-position of thieno[3,2-d]pyrimidine moiety lead to detrimental activity but had good selectivity towards HT-29 and H460 cell lines. In the enzymatic evaluation, it was found that the compound was active against the PI3K $\alpha$ kinase $\left(\mathrm{IC}_{50}=0.13 \mu \mathrm{M}\right)$. The apoptosis in the cancer cell was induced by the compound in concentration dependent manner with the increase in protein expression of Clv-PARP [113]. Diaryl semicarbazone linked to thieno $[3,2-\mathrm{d}]$ pyrimidine derivatives as potential antitumor agent were studied in the same year. 111 was the most potent compound of the series with the $\mathrm{IC}_{50}=0.23$ to $0.57 \mu \mathrm{M}$ against the tumor cell lines
H460, MKN-45, MDA-MB-231 and HT-29 using MTT assay and sorafenib and GDC-0941 as positive control. The compound also showed promising activity against the PI3K $\alpha$ better than the standard reference GDC-0941 indicating that the compound will make this particular kinase enzyme a potential target in future. By the help of the western blot method, it was determined that the compound can be used for induction of apoptosis in a concentration dependent manner [114].

Recently, the biological activity of the new series of novel thieno[3,2-d]pyrimidine derivatives were reported along with the test for the fak inhibition. These compounds were designed in a way that it mimics the conformation of the diaminopyrimidine moiety. 112 most potently inhibited the enzyme with the $\mathrm{IC}_{50}(28.2=\mathrm{n}$ $\mathrm{M})$ and also acted against the proliferation in the U87MG, A-549, and MDA-MB231 cancer cell lines with the $\mathrm{IC}_{50}=0.16,0.27$ and $0.19 \mu \mathrm{M}$ respectively and was less toxic to $\mathrm{HK} 2$ cell line. It arrested the cell cycle at G0/G1 phase in the MDA-MB231 cancer cell line, also preventing the migration and induced apoptosis [115]. HDAC was inhibited by novel thieno [3, 2-d] pyrimidines and for their anticancer activity was evaluated on three cell lines including, MCF-7, HeLa, and HCT-116 by using MTT assay. The HDAC inhibition in the compound was studied using fluorimetric assay. 113 inhibited HDAC potently with the $\mathrm{IC}_{50}=0.38 \mu \mathrm{M}$ by inducing apoptosis in HCT-116 cell line and cell cycle arrest at G2/M phase with SAHA as positive control [116].

Thieno [2, 3-d] pyrimidine and thieno [3, 2-e] triazolo [4, 3c] pyrimidine

Thieno [3, 2-e] triazolo [4, 3-c] pyrimidine and thieno [2, 3-d] pyrimidine derivatives were reported for antiproliferative activity. 114 elucidated the most potent results against the 56 tumor cell lines with higher selectivity for breast cancer cell lines. Compound $\mathbf{1 1 4}$ arrested the cell cycle at the $\mathrm{G} 2 / \mathrm{M}$ phase and the accumulation of the cells from the degradation and fragmentation of the genetic material started from the pre G1 phase of the cell cycle in the MDA-MB-468 cell line leading to induction of apoptosis in the cancer cells [117]. Previously, the thieno [3, 2-e] triazolo [4, 3-c] pyrimidines and thieno [2, 3-d] pyrimidine-4-ones were studied for activity on the HCT-116 tumor cell line, using SRB assay. 115(a-e) with $\mathrm{IC}_{50}=11.90,12.43,15.91,25.80$, and $32.11 \mu \mathrm{M}$ respectively showed potent antitumor activity against the said cell line. The compounds had 2.89-1.07-fold more activity than positive control imatinib $\left(\mathrm{IC}_{50}=34.4 \mu \mathrm{M}\right)$. In the SAR study, it has been summarized that substitution at C-2 position highly affects the potency and presence of methylene between electronegative moieties and pyrimidin-4-one ring, $\mathrm{Cl}$, and arylamino increases the 
activity. Arylcarbothioyl derivative did not affect the activity, whereas the 2-nitrophenyl group increased the activity by 2.89 folds. Molecular docking was used to study the binding and affinity of the compound towards the CDK2 receptor [118].

\section{Other thieno pyrimidine derivatives}

In silico method was used to determine the anticancer activity of new annelated thieno [2, 3-e ][1-3] triazolo $[1,5-a]$ pyrimidines, using 60 human cancer cell lines. Compounds 116(a-b) were the most potent and showed high antiproliferative activity at sub micromolecular concentration with low toxicity to normal cells and highly potent towards cancer cells. The basic chain histamine or methylpiperazine was important for potency enhancement of the activity and the isosters pyridothieno were less effective than the benzothieno bicycle [119]. Using the unusual dimroth rearrangement in an in silico research study conducted simultaneously led to synthesis of annelated thieno[3,2-d][1,2,3] triazolo[1,5-a]pyrimidines. 117a (angular isomers) showed excellent anticancer activity against the 60 cancer cell line panel at sub $\mathrm{nM}$ concentration. Compound 117b (linear isomer) displayed good antiproliferative activity. In the preliminary in vivo test of compound $\mathbf{1 1 7} \mathbf{b}$, it showed high potency (Fig. 36) [120].

\section{Thiazolopyrimidine derivatives \\ Thiazolo [1, 2-a] pyrimidine}

3-carboxylate derivatives of benzo [4,5]thiazolo [1, 2-a] pyrimidines were reported and $118(\mathbf{a}-\mathbf{b})$ displayed potency against MDA-MB-231 and MCF-7 cancer cell lines. Compound 118a showed activity against both with the $\mathrm{IC}_{50}=0.58$ and $1.58 \mu \mathrm{M}$ respectively, and $118 \mathrm{~b}$ had the best activity against MDA-MB-231 with the $\mathrm{IC}_{50}=$ $5.01 \mu \mathrm{M}$. The activity was imparted to the MCF-7 and MDA-MB231 due condensation of methyl piperazine and piperidine with carboxylic acid at 3 '-position of the benzothiazopyrimidine ring. Condensation of $\beta$-alanine at the third position of benzothiazopyrimidine ring led to increase in chain length subsequently decreasing the activity compared to piperidine and methylpiperazine moieties [121].

\section{Thiazolo [3,2-a]pyrimidines}

Recently, thiazolo [3, 2-a] pyrimidine derivatives were tested for anticancer activity against MCF-7, HeLa, A549, and SKNSH by MTT assay. 119a with $\mathrm{IC}_{50}=2.2$ $\pm 0.6 \mu \mathrm{M}$ against $\mathrm{A} 549$ and compound $119 \mathrm{~b}$ with $\mathrm{IC}_{50}=$ $5.6 \pm 0.4 \mu \mathrm{M}$ against HeLa exhibited better effects than positive control DOX. The presence of methoxyphenyl groups and naphthyl on thiazolopyrimidine demonstrated enhanced activity [122]. Novel thiazolo [3, 2-a] pyrimidines were screened for in vitro antiproliferative

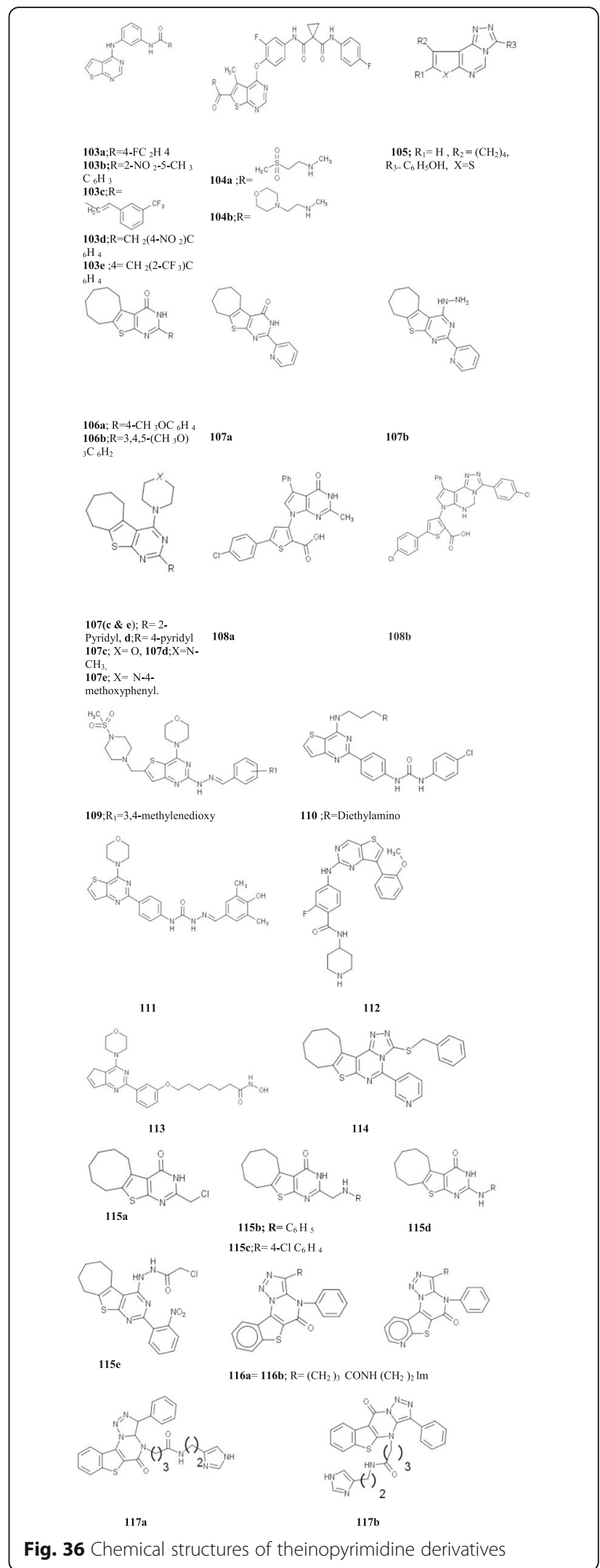

Fig. $\mathbf{3 6}$ Chemical structures of theinopyrimidine derivatives 


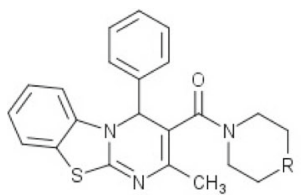

$118 \mathrm{a} ; \mathrm{R}=\mathrm{CH}_{2} ;$ $118 \mathbf{b} ; \mathrm{R}=\mathrm{N}-\mathrm{CH}_{3}$

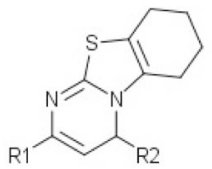

$119 a ; R_{1}=2-N a p h t h y l$, $\mathrm{R}_{2}=3,4,5-$ trimethoxyphenyl 119b; $\mathrm{R}_{1}=2-\mathrm{Naph}$ $2=3$-Bromophenyl

Fig. $\mathbf{3 7}$ Chemical structures of thiazolopyrimidine derivatives

activity, 120(a-b) showed the best activity against 60 cancer cell line panel. Three cancer cell lines Hop-92, SK-MEL-2, and IGROV1 exhibited some potency towards the compounds out of the 60 cancer cell lines during the in vitro anticancer activity assay. In the molecular docking studies, it was summarized that some compounds of the series fit into the minor groove and bind to the AT base pairs and thus had shown anticancer activity (Fig. 37) [123].

Novel pyrido [4, 3-d] fused with thiazolo [3, 2-a] pyrimidine analogs were tested for anticancer activity against the panel of 60 cancer cell lines. 121(a-b) were 9-folds more active with the $\mathrm{IC}_{50}=2.4$ and $9.1 \mu \mathrm{M}$ and compounds $\mathbf{1 2 1}(\mathbf{c}-\mathbf{d})$ were 7 -fold more active with the $\mathrm{IC}_{50}=3$ and $16.3 \mu \mathrm{M}$ better than the standard reference drug 5 -FU $\left(\mathrm{IC}_{50}\right.$ range $=36$ to $\left.54 \mu \mathrm{M}\right)$. SAR is illustrated in Fig. 38 [124].

Thiazolo[3,2-a] pyrido[4,3-d]pyrimidine containing derivatives were evaluated against the 60 different human tumor cell lines with $\mathbf{1 2 2}(\mathbf{a}-\mathbf{m})$ being the most potent. The different activity between the compounds was due to variation of substitutions in the phenyl group of the molecule and the presence of sulfur and nitrogen atom subsequently enhanced the activity. Thiopyrimidine moieties fused to $\mathrm{N}$-methylpipredine ring boosted the activity [125].

\section{Thiazolo [5, 4-d] pyrimidines}

Apoptosis-inducing and antiproliferative activity of thiazolo [5,4-d]pyrimidines were reported using the SRB assay against cancer cell lines A549, A431, T98G, T47D, PC-3, HL-60, NCI-H322, and MIAPaCa-2. 123 showed the induction of apoptosis in A549 cells at the concentration of $10 \mu \mathrm{M}$ determined by the high sub -G1 population. In the western blotting assay, the compound demarcated cleavage in PARP-1 and lead to procaspase3 inhibited apoptosis [126]. The study of some thiazolo [5,4-d]pyrimidine derivatives were carried out by the
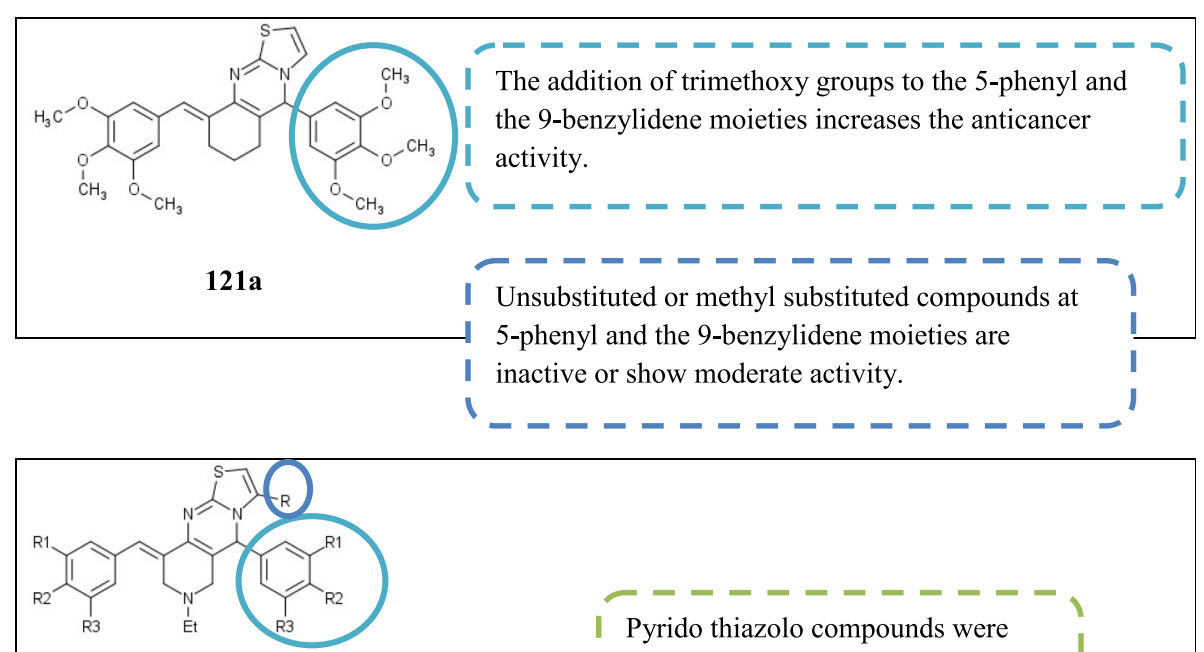

121b; $\mathrm{R}=\mathrm{R}_{1}=\mathrm{R}_{3}=\mathrm{H}, \mathrm{R}_{2}=\mathrm{OCH}_{3}$

121c $; \mathrm{R}_{1}=\mathrm{R}_{2}=\mathrm{OCH}_{3}, \mathrm{R}=\mathrm{R}_{1}=\mathrm{H}$

121d; $\mathrm{R}=\mathrm{CH}_{3}, \mathrm{R}_{1}=\mathrm{R}_{2}=\mathrm{OCH}_{3}, \mathrm{R}_{3}=\mathrm{H}$

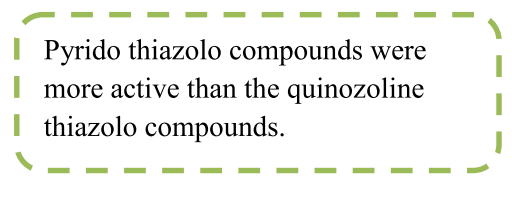

Fig. 38 Chemical structure and SAR studies of novel pyrido [4, 3-d] fused thiazolo [3,2-a]pyrimidine analogs 
drug repurposing strategy and evaluated against three cancer cell lines. 124 showed the best anti-cancer activity with the $\mathrm{IC}_{50}=1.03$ and $38.95 \mu \mathrm{M}$ against the MGC803 and GES1 cell lines respectively, with efficient selectivity between cancer cell and normal cells. The compound also inhibited the formation and migration of MGC803 cells and also led to apoptosis by expression of some changes in the apoptosis concerned proteins by upregulation of Bax and caspase-3/9 and downregulation of Bcl-2, confirmed by the western blot assay [127].

The antiproliferative activity of novel thiazolo [5,4d]pyrimidines were evaluated. $\mathbf{1 2 5}$ exhibited efficacious selectivity between the human cells and cancer cells which was confirmed as it had $\mathrm{IC}_{50}=1.22 \mu \mathrm{M}$ against HGC-27 cell line and low toxicity towards the GES-1 cells. The induction of apoptosis was due to upregulated expression of Bax, downregulation of Bcl-2, and cleavage in caspased-3/9. It also prevented the migration and formation of new HGC-27 cell proving it as an efficacious lead for future anticancer drugs [128].

\section{Other thiazolopyrimidine derivatives}

Novel 1-thia-4-azaspiro [4.5] decane and their derived thiazolopyrimidines were studied for activity against the HepG-2, PC-3 and HCT116 cancer cell lines. 126(a-b) showed good anticancer activity against the HCT116 cell line with the $\mathrm{IC}_{50}$ range $=92.2$ to $120.2 \mu \mathrm{M}$ and showed some activity against the HepG-2 cell line. The MTT assay was conducted for the cytotoxicity with compound dosage of $100 \mathrm{ppm}$ and DOX was used as positive control (Fig. 39) [129].

\section{Oxazolo-pyrimidine derivatives}

Recently, work on the anticancer activity of some 4(Oxazolo [5,4-d]pyrimidine derivatives linked with 1,2,4oxadiazole was reported. Compounds were tested against the human breast, lung, colon, and ovarian cancer cell line using the MTT assay with etoposide as the positive control. 127a showed activity against all the cancer cell lines with the $\mathrm{IC}_{50}$ range $=0.046$ to $0.12 \mu \mathrm{M}$ and $127 \mathrm{~b}$ showed activity against cell lines namely breast, lung, and ovarian cancer with the $\mathrm{IC}_{50}$ range $=0.012$ to 0.63 $\mu \mathrm{M}$. In the SAR studies, it was concluded that the compound with an EDG had the most potent activity and compounds with 3,5-dimethoxy, 4-methoxy group depicted low activity. Compounds with one nitro group had moderate activity whereas the ones with bromo di nitro group had good activity. A weak EDG group with the compound showed considerable activity [130].

New series of oxazolo [5,4-d]pyrimidines were reported as efficacious VEGFR-2 inhibitors. The compounds were tested against HUVEC and VEGFR-2 with 128 being the most potent in the series with the $\mathrm{IC}_{50}=$ $0.33 \mu \mathrm{M}$ for VEGFR-2 and $\mathrm{IC}_{50}=0.29 \mu \mathrm{M}$ for HUVEC.
Compounds of this series were also moderate inhibitors of EGFR and sunitib was used as positive control [131]. In a parallel study, a newly synthesized oxazolo[5,4d]pyrimidine derivative, $\mathbf{1 2 9}$ was reported. HUVEC was inhibited in a dose dependent manner with the $\mathrm{IC}_{50}=$ $9.30 \pm 1.24 \mu \mathrm{M}$. Reported in other in vitro and ex vivo studies, it also inhibited new micro vessels sprouting from rat aortic ring. The migration and chemotactic invasion was stopped along with the downstream signaling of VEGFR-2 and downregulation of phosphorylation of PI3K, ERK1/2, and p38 MAPK (Fig. 40) [132].

\section{Quinazoline containing derivatives}

Anticancer activity of 2,3-disubsituted quinazoline was reported and the compounds were tested using MTT assay against MCF-7 cancer cell line with amphotericin $\mathrm{B}$ as positive control. 130(a-c) exhibited anticancer with an $\mathrm{IC}_{50}(\mu \mathrm{M})=6,6$, and 4 respectively [133]. New quinazoline derivatives were being studied for anticancer activity against the MDA-MB231 and HeLa cancer cell lines, using MTT assay, while using gefitinib as positive control. 131 $(\mathbf{a}-\mathbf{c})$ had the lowest $\left(\mathrm{IC}_{50}=1.85\right.$ to 2.81 $\mu \mathrm{M})$ in relation to gefitinib $\left(\mathrm{IC}_{50}=4.3\right.$ and $\left.28.3 \mu \mathrm{M}\right)$ against MDA-MB231and HeLa cells, respectively. They were deemed as most potent because they acted through EGFR-TK pathway. The addition of heteroalkyl atom led to decrease in cytotoxicity. The $\mathrm{NO}_{2}, \mathrm{CN}$, phthalimido, and morpholino groups alongside the $\mathrm{N}$-benzyl group and the substitution at $R_{2}$ position affected the cytotoxic activity to a great extent [134].

2-furano-4(3H)-quinazolinones, diamides (open ring quinazolines), and quinoxalines were evaluated against OVCAR-4 and NCI-H522 cancer cell lines and 132 was found to be the most efficient compound. The potency was due to the blocking of hydrophobic pocket of tyrosine kinase because of 2-chloro benzylideneamine group at 3-position of quinazoline. The presence of $\mathrm{OH}$ and benzoic acid at $\mathrm{N} 3$ of the ring lowered the activity whereas 2-chloro benzylideneamine group increased activity [135].

Quinazoline derivatives incorporated with chalcone were tested against cancer cell lines MCF-7, A375, A549, and HT-29, using MTT assay. 133a $\left(\mathrm{IC}_{50}=0.18\right.$ to $2.90 \mu \mathrm{M}), \mathbf{1 3 3 b}\left(\mathrm{IC}_{50}=0.10\right.$ to $\left.1.34 \mu \mathrm{M}\right), \mathbf{1 3 3 c}\left(\mathrm{IC}_{50}\right.$ $=0.10$ to1.56 $\mu \mathrm{M})$, and $133 \mathrm{~d}\left(\mathrm{IC}_{50}=0.16\right.$ to $\left.2.89 \mu \mathrm{M}\right)$ showed more potent activity than the control drug, combretastatin-A4 [136]. Previously, in a report on antibreast cancer activity of novel quinazoline derivatives, they were evaluated against MCF-7 cancer cell line by resazurin reduction method and DOX as positive control. Oxadiazole, pyrazole, and thiazolidinone-linked quinazolin-4-one scaffold, 134(a-d) (containing thiazolidinone moieties) displayed the best activity with $\mathrm{IC}_{50}=$ 3 to $9 \mathrm{nM} / \mathrm{mL}$ [137]. 


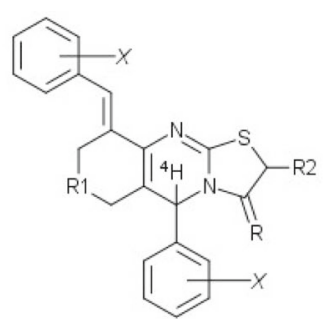

122

a; $\mathrm{X}=4-\mathrm{F} \mathrm{R}_{1}=\mathrm{N}-\mathrm{CH}_{3}$

$\mathrm{R}=\mathrm{R}_{2}=\mathrm{H}$

b; $\mathrm{X}=2-\mathrm{Cl} \mathrm{R}{ }_{1}=\mathrm{N}-\mathrm{CH}_{3}$

$\mathrm{R}=\mathrm{R}_{2}=\mathrm{H}$

c; $\mathrm{X}=3-\mathrm{Cl} \mathrm{R}{ }_{1}=\mathrm{N}-\mathrm{CH}_{3}$

$\mathrm{R}=\mathrm{R}_{2}=\mathrm{H}$

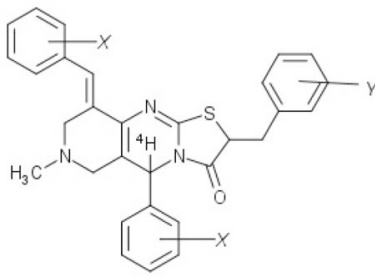

j; $\mathrm{X}=\mathrm{H}, \quad \mathrm{Y}=4-\mathrm{Cl}$

k; $\mathrm{X}=4-\mathrm{Cl}, \mathrm{Y}=4-\mathrm{F}$

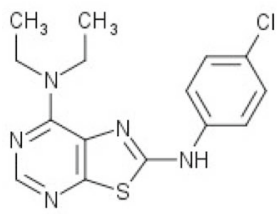

123

124 d; $\mathrm{X}=\mathrm{H} \mathrm{R} \mathrm{R}_{1}=\mathrm{N}-\mathrm{CH}_{3} \quad \mathrm{R}=\mathrm{O} \mathrm{R} \mathrm{R}_{2}=\mathrm{H}$

e; $\mathrm{X}=4-\mathrm{F} \mathrm{R}_{1}=\mathrm{N}-\mathrm{CH}_{3} \quad \mathrm{R}=\mathrm{O} \mathrm{R}_{2}=\mathrm{H}$

f; $\mathrm{X}=4-\mathrm{Cl} \mathrm{R}{ }_{1}=\mathrm{N}-\mathrm{CH}_{3} \quad \mathrm{R}=\mathrm{O}$

$\mathrm{R}_{2}=\mathrm{H}$ g ; $\mathrm{X}=4-\mathrm{F} \quad \mathrm{R}_{1}=\mathrm{H}-$

$\mathrm{CH}_{3} \mathrm{R}=\mathrm{O} \mathrm{R}=\mathrm{CH}_{3}$

h; $\mathrm{X}=4-\mathrm{Cl} \mathrm{R}=\mathrm{H}$ -

$\mathrm{CH}_{3} \mathrm{R}=\mathrm{O} \mathrm{R}_{2}=\mathrm{CH}_{3}$

i; $\mathrm{X}=4-\mathrm{F} \quad \mathrm{R}_{1}=\mathrm{H}-\mathrm{CH}_{3}$

$\mathrm{R}=\mathrm{O} \mathrm{R}_{2}=\mathrm{CH}_{3}$

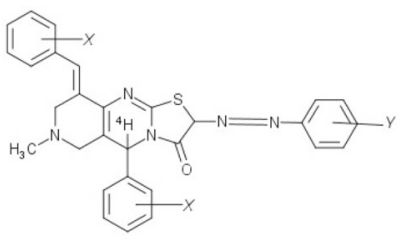

l; $\mathrm{X}=4-\mathrm{Cl}, \mathrm{Y}=\mathrm{H}$

m; $\mathrm{X}=4-\mathrm{Cl}, \mathrm{Y}=4-\mathrm{O} \mathrm{CH}_{3}$
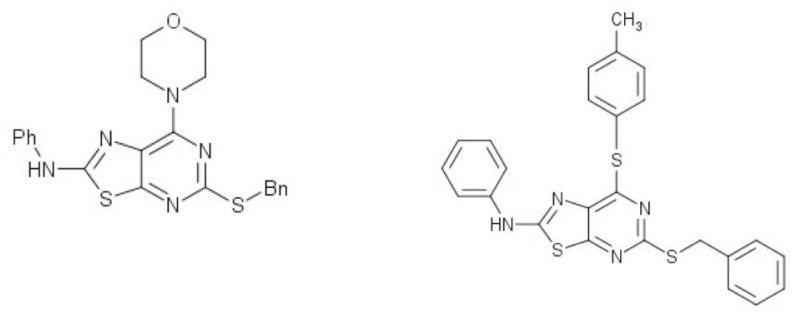

125

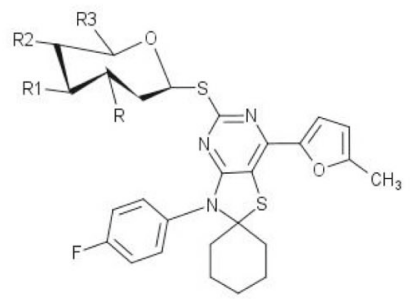

126a $; \mathrm{R}=\mathrm{R}_{1}=\mathrm{R}_{2}=\mathrm{OAc}$,

$\mathrm{R}_{3}=\mathrm{CH}_{2} \mathrm{OAc}$

126b; $\mathrm{R}=\mathrm{R}_{1}=\mathrm{R}_{2}=\mathrm{OH}$,

$\mathrm{R}_{3}=\mathrm{CH}_{2} \mathrm{OH}$

Fig. 39 Chemical structures of some thiazolo pyimidine derivatives

Novel amine substituted quinozoline-linked benzimidazole compounds were tested for antitumor activity. 135 elucidated the best activity against the prostate and colon cancer cell lines. In the SAR studies, it was revealed that the substituents at $\mathrm{C}-2$ and $\mathrm{C}-4$ position of the quinozoline ring affected the activity of the compounds and with benzimidazole at the C-4 position it also possessed growth inhibition property
[138]. A regioisomeric series of quinazoline and benimidazole hybrids were studied as anticancer agents and screened against a panel of 60 cancer cell lines. 136 was most potent of all, better than 5-FU (positive control) [139].

A series of quinozoline derivatives were reported in a simultaneous study for their activity against human tumor cell lines derived from 9 different 
<smiles>[R1]c1cccc(-c2nc(-c3ccc(-c4nc5cncnc5o4)cc3)no2)c1</smiles>

127a; $\mathrm{R}_{1}=3,4,5$-trimethoxy<smiles>COc1ccc(-c2nc3c(Nc4ccc(C)cc4)nc(C)nc3o2)cc1</smiles>

128<smiles>COc1ccc(-c2nc3c(Nc4ccc(NC(=O)c5ccc(Cl)cc5)cc4)nc(C)nc3o2)cc1</smiles>

129

Fig. $\mathbf{4 0}$ Chemical structures of oxazolo pyrimidine derivatives<smiles>[R]n1c(-c2ccccc2)nc2ccccc2c1=O</smiles>

130a; $\mathrm{R}=$ Benzene $130 \mathrm{~b} ; \mathrm{R}=3$ -

Chlorobenzene 130c; $\mathrm{R}=\mathrm{p}$-toluene<smiles>[R9]CCN([R])c1nc2ccccc2c(=O)n1CC</smiles>

131a; $\mathrm{R}_{3}=$ Methyl, $\mathrm{R}_{1}=$ Benzyl, $\mathrm{R}_{2}=3$ (Phthalimido-2-yl) propyl

131b; $\mathrm{R}_{3}=$ Methoxy, $\mathrm{R}_{1}=$ Benzyl, $\mathrm{R}_{2}=3$-(Phthalimido2-yl) propyl

131c; $R_{3}=$ Methoxy, $\mathrm{R}_{1}=$ Benzyl, $\mathrm{R}_{2}=$ Morphilinoethyl<smiles>[R]c1cccc(C(=O)/C=C/c2ccc(Nc3ncnc4ccccc34)cc2)c1</smiles>

$133 \mathrm{a} ; \mathrm{R}_{1}=2$-fluoro-4trifluoromethy 133b; $\mathrm{R}_{1}=4$-trifluoromethyl 133c; $R_{1}=3$,4-dimethoxy 133d; $R_{1}=4$-methoxy<smiles>C=CCn1c(C)nc2ccc(Nc3nc(NCCC)nc4ccccc34)cc21</smiles>

136; $\mathrm{N} \mathrm{R}_{1} \mathrm{R}_{2}=$ Pyrrolidin-1-yl<smiles>O=c1c2ccccc2nc(-c2ccco2)n1/N=C/c1cccc(Br)c1</smiles>

132; $\mathrm{R}_{1}=2$-chloro

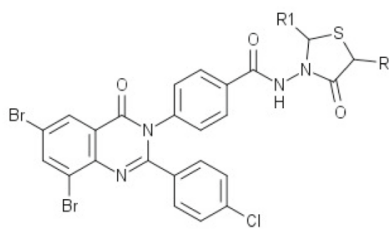

134a; $\mathrm{R}=\mathrm{H}, \mathrm{R}_{1}=\mathrm{p}$ - toluene 134b $; \mathrm{R}=\mathrm{H}, \mathrm{R}_{1}=2$-hydroxyPh

$134 \mathrm{c} ; \mathrm{R}=$

$\mathrm{R}_{1}=$ benzene

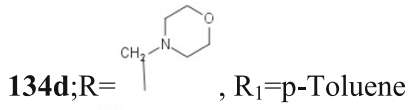<smiles>O=C(O)NNc1ncnc2ccccc12</smiles>

137; $\mathrm{R}=3,4,5$ -

Trimethoxybenzene

Fig. 41 Chemical structures of some quinazoline derivatives 
<smiles>Cc1sc2nc3c(C(=O)NCCN(C)C)cccn3c(=O)c2c1C</smiles>

138<smiles>CCOC(=O)C1C(c2ccccc2)N=C2SC=C(c3ccc(Cl)cc3)N2C1c1ccc(Cl)cc1</smiles>

140<smiles></smiles>

$141 b$

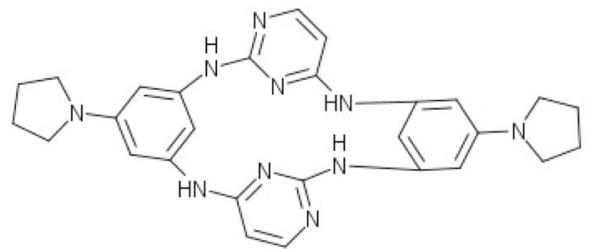

143<smiles>COc1cc(/C=N/Nc2nc3c(c(N4CCOCC4)n2)SCCC3)cc(OC)c1O</smiles><smiles>[R]c1nnc2nc3c(c(C)n12)OC(c1ccccc1)=NN3C</smiles>

139a $; \mathrm{R}=\mathrm{CH}_{3}, \mathbf{1 3 9} \mathbf{b} ; \mathrm{R}=\mathrm{SCH}_{2} \mathrm{CN}$<smiles>CC1=NC2=NN3C(=NN2C(c2ccccc2)=C1)N=C(C)CC3c1ccccc1</smiles>

141a

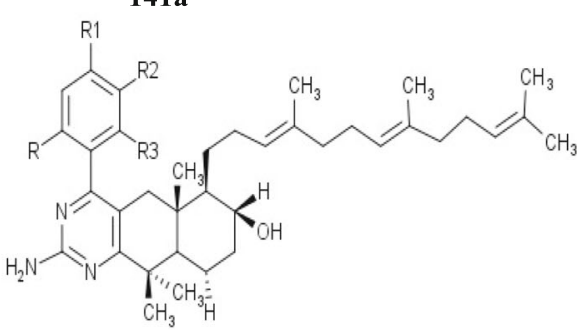

142a; $\mathrm{R}=\mathrm{R}_{2}=\mathrm{R}_{3}=\mathrm{H}, \mathrm{R}_{1}=\mathrm{Br}$

142b; $\mathrm{R}=\mathrm{R}_{2}=\mathrm{R}_{3}=\mathrm{H}, \mathrm{R}_{1}=\mathrm{Cl}$<smiles>O=C(O)c1ccc2occ(/C=N/Nc3nc4c(c(N5CCOCC5)n3)SCCC4)c(=O)c2c1</smiles>

144a

\section{4b}

Fig. 42 Chemical structures of some miscellaneous fused ring containing pyrimidine derivatives

sources using the SRB assay. 137 showed antiproliferative potency against all the cell lines due to the presence of the phenylvinylic substituent at 2 position. Other compounds with methylene, trichlorophenoxymethylene, and benzyl displayed moderate activity against specific cell lines (Fig. 41) [140].

\section{Miscellaneous fused ring pyrimidine derivative}

Some novel pyrido-thieno-pyrimidine derivatives were responsible for the induction of phosphorylation and acetylation which led to the activation of p53 in the colorectal cancer cells. 138 was responsible for the p53mediated activity which led to activation of downstream 


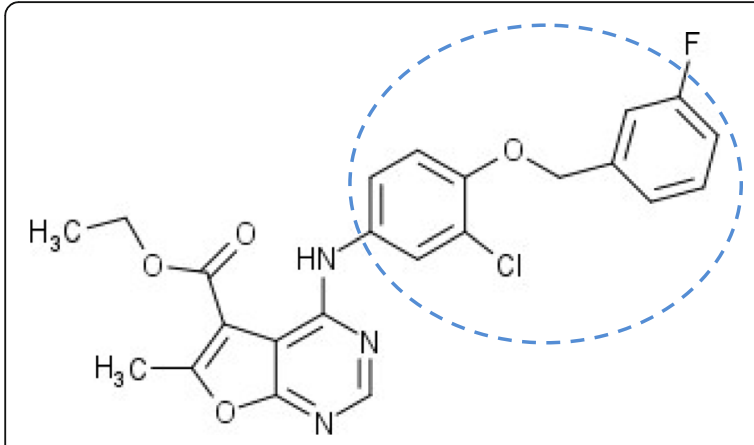

Presence of the ester moiety linking aniline to the benzene ring makes the compound more hydrophobic and it can easily penetrate through the cell membrane thus, increasing activity.

\section{5}

Fig. 43 SAR and chemical structure of novel anilino pyrimidine derivative

genes like p51 and PUMA (which resulted towards delay in growth, cell cycle stoppage at G1, cell senesce, and cell death). Controlled interaction between p53 and MDM2 led reduced degradation of p53 and due to these attributes, 138 was considered a potential anticancer agent [141]. Pyrimidooxadiazine and triazolopyrimidooxadiazine derivatives were reported as anticancer agents. 139(a-b) elucidated the best potency against the A549, MCF7, and HepG2 cancer cell lines because of the change in substitutions at triazole moiety fused to pyrimido[4,5e][1,3,4] oxadiazine heterocyclic ring and C-7 position. Compounds with fused triazole ring were more active compared to the chlorine or pyrrolidine moiety at the $\mathrm{C}-7$ position. Induction of cell death by apoptosis was caused by various cellular modifications such as biochemical changes like protein cleavage, protein crosslinking, DNA fragmentation, and phagocytic recognition [142].

Recently, a novel series of thiazolopyrimidine hydrobromides and triazolopyrimidines which act as topoisomerase II inhibitors was reported. The compounds were screened against 60 human cancer cell lines by the MTT colorimetric assay. Results elucidated 140 as the most significant inhibitor against the $\mathrm{A} 498\left(\mathrm{IC}_{50}=3.5\right.$ $\mu \mathrm{M})$ cell line. The cell cycle was arrested at the G2/M phase leading to inhibition of cell proliferation and induced apoptotic activity. 140 also elucidated potent topoisomerase II inhibitory activity $\left(\mathrm{IC}_{50}=2.89 \mu \mathrm{M}\right)$ versus DOX $\left(\mathrm{IC}_{50}=2.67 \mu \mathrm{M}\right)$ which was used as a positive control [143].

Fused pyrimidine hybrids were tested using MTT assay against the B-16, A-549, MCF-7, ACHN, and COLO-205 cancer cell lines. 141a $\left(\mathrm{IC}_{50}=9.5 \mu \mathrm{M}\right)$ and 141b $\left(\mathrm{IC}_{50}=7.7 \mu \mathrm{M}\right)$ showed the best activity against A549 cancer cell line due to induction of apoptosis at the G0/G1 phase of the cell cycle. SAR suggested that 4chloro and 4-bromo pyrimidine hybrid have 5-6 times more activity against the A-549 whereas 2-3 times more activity against the other abovementioned cell lines than the parent compound [144]. Novel azacalix[2]aren e[2] pyrimidines were screened against the MCF-7 cancer cell line. 142(a-b) were the best with anticancer activity with the $\mathrm{IC}_{50}=0.58$ and $1.82 \mu \mathrm{M}$ respectively. Phenyl ring containing pyrrolidine group shows good ctytotoxic activity against A549, MCF7, and SHSY5Y cell lines but not against L02 cells. Compounds methyl and methoxy substituent on phenyl ring instead of no substitutions shows decreased activity. Other substitutions on the phenyl ring gave moderate activity whereas $\mathrm{CF}_{3}$ group on the phenyl ring showed good activity [145].

Chromone moiety bearing 7,8-dihydro-5H-thiopyrano[4,3-d]pyrimidine derivatives was tested against PC3, A549, MCF-7, HepG2, and Hela cancer cell lines using MTT assay. Compound 143 showed excellent cytotoxicity and inhibitory activity against PI3Ka kinase, mTOR kinase, and the five cancer cell lines with $\mathrm{IC}_{50}=$ $1.1 \mu \mathrm{M}, 0.92 \mu \mathrm{M}$, and 8.77 to $14.3 \mu \mathrm{M}$ respectively. The presence of morpholine group and hydrazinyl group led to the anticancer activity [146]. Previously, antitumor activity of new 4-morpholino-7,8-dihydro-5H-thiopyrano[4,3-d]pyrimidines due to variations in substitutions of the aryl moiety and 4-OH substitution was reported. 144a and 144b showed strong antitumor activities against mTOR kinase, $\mathrm{PC}-3$, and $\mathrm{H} 460$ cell lines with $\mathrm{IC}_{50}=0.80 \pm 0.15 \mu \mathrm{M}, 11.90 \pm 0.94 \mu \mathrm{M}$, and $7.43 \pm 1.45$ $\mu \mathrm{M}$ respectively (Fig. 42) [147].

Novel anilino pyrimidine derivatives were evaluated in 2018 and compound $145\left(\mathrm{IC}_{50}=0.5 \mu \mathrm{M}\right)$ depicted the most potent anticancer activity against A549 cell line mainly due to the presence of the linkage via ester moiety. SAR is illustrated in Fig. 43 [148].

\section{Conclusions}

Pyrimidine is a significant scaffold due to its presence in naturally occurring nucleotides and is being explored extensively for its anticancer profile. The present manuscript has discussed the anticancer potential of substituted pyrimidine at various positions as well as 
pyrimidine fused with other heterocyclic ring. Substitutions at the C-2, C-4, and C-6 position of the pyrimidine core has a great influence on the antitumor activity especially a thio or amino group at C-2 and substituted phenyl group at $\mathrm{C}-4$. Pyrimidine fused with five member rings like pyrazolo, pyrrolo, triazolo, imidazole, oxazolo, thiazolo, and thieno exhibited more distinct anticancer activity compared to the six member rings like pyrido and quinazoline. Pyrimidine analogs act as anticancer agent through diverse mechanism of action including, kinase (erbB2, raf, CDK, Src etc.) enzyme inhibition, cell cycle arrest, activation of oncogenes, reduction of mitochondrial membrane potential, increase of ROS, and induction of apoptosis by upregulation of apoptotic and downregulation of anti-apoptotic proteins. The current manuscript can be valuable to scientists and researchers around the globe to optimize and select specific targets for the development of potent lead molecules as anticancer agents in future.

\begin{abstract}
Abbreviations
SAR: Structure activity relationship; EDG: Electron donating group; EWG: Electron withdrawing group; DNA: Deoxyribonucleic acid; RNA: Ribonucleic acid; $I C_{50}$ : Half minimal inhibitory concentration; DOX: Doxorubicin; 5-FU: 5-Fluorouracil; ROS: Reactive oxygen species; EGFR: Epidermal growth factor receptor; COX-2: Cyclooxygenase-2; PRAP: Poly ADP ribose polymerase; FAK: Focal Adhesion Kinase; Raf: Rapidly accelerated fibrosarcoma; Pim-2: Serine/ threonine-protein kinase; erbB2: Receptor tyrosine protein kinase; VEGFR: Vascular endothelial growth factor receptor; S-Phase: Synthesis phase; GO Phase: Resting phase; CDK: Cyclin-dependent kinases; Bcl: B-cell lymphoma; PTK: Protein kinase inhibitor; PDGFR: Platelet-derived growth factor receptor; STAT: Signal transducer and activator of transcription; HDAC: Histone deacetylase; VLAK: Virtual Lock-and-Key; PI3K: Phosphoinositide 3-kinase; MAPK: Mitogenactivated protein kinase; ER: Estrogen receptors; EAC: Elrich ascities carcinoma; XIAP: X-linked inhibitor of apoptosis protein; DNMT: DNAmethyltransferase; RET: Receptor tyrosine kinase; LSD-1: Lysine specific demethylase-1
\end{abstract}

\section{Assays}

SRB: Sulforhodamine-B; MTT: 3-(4,5-dimethylthiazol-2-yl)-2,5-diphenyl tetrazolium bromide; ELISA: Enzyme-linked immunosorbent assay; CAM: Chick Chorioallantoic membrane; LDH: Lactate dehydrogenase

\section{Cancer cell lines}

Breast: MCF7, T47D, BT-474, MDA-MB-231, MDA-MB-453, BT-549MCF10A-ras, Bcap-37, MDA361, MDA MB468, SK-BR-3; Colon: Caco-2, HT29, SW620, Colo205, HCT-8, HCT-15, HCT-116, SW707; Lung: A-549, HOP-92, HOP62, NCI-H460, Hop-92, NCl-H522, NCl-H322, NCl-H23, HTB-54, H 460, H69AR; Leukemia: THP1, Molt-4, P-388, L1210, HL-60, K-562, MEG-01, KU-812, CLL, U937, MCL-1 (myeloid cell leukemia 1), K-562 (chronic lymphocytic leukemia), CEM-13; Melanoma: B16F10, SK-MEL-2, A375, RPMI-8226; Ovary: IGROV-1, OVCAR-8, SKOV-3, OVCAR-3, OVCAR-4, A2780; Liver: HEP-2, epG2, SK-Hep-1, Hep3B, BEL7402; Prostate: DU-145, PC-3, RWPE-1, LNCaP; Stomach: SGC-7901; Huh7, HGC-27; Cervical cancer: HeLa; Gastric cancer cell line: MGC-803, SNU-638; Esophageal: EC-109, EC-9706; Neuroblastoma: SH-SY5Y; Kidney: CAKI-I, A498; Human osteosarcoma: SaOS-2; Connective tissue: HT-1080; Pancreatic: PANC1; Urinary bladder: T-24

\section{Acknowledgements}

Authors are thankful to the Siksha O Anusandhan (deemed to be University) Bhubaneswar for the support provided.

\section{Authors' contributions}

AM, TP, and TS have equally contributed to this work. The authors read and approved the final manuscript.

\section{Funding}

No funding received for the study.

Availability of data and materials

Not applicable

\section{Declarations}

Ethics approval and consent to participate

Not applicable

\section{Consent for publication}

Not applicable

\section{Competing interests}

The authors declare that they have no competing interests.

Received: 20 April 2021 Accepted: 31 May 2021

Published online: 19 June 2021

\section{References}

1. Miller KD, Nogueira L, Mariotto AB, Rowland JH, Yabroff KR, Alfano CM, Jemal A, Kramer JL, Siegel RL (2019) Cancer treatment and survivorship statistics. CA Cancer J Clin 69(5):363-385 https://doi.org/10.3322/caac.21565

2. MohanaRoopan S, Sompalle R (2016) Synthetic chemistry of pyrimidines and fused pyrimidines: a review. Synth Commun 46(8):645-672 https://doi. org/10.1080/00397911.2016.1165254

3. Prachayasittikul S, Pingaew R, Worachartcheewan A, Sinthupoom N, Prachayasittikul V, Ruchirawat S, Prachayasittikul V (2017) Roles of pyridine and pyrimidine derivatives as privileged scaffolds in anticancer agents. MiniRev Med Chem 17(10):869-901 https://doi.org/10.2174/13895575166661 60923125801

4. Selvam TP, James CR, Dniandev PV, Valzita SK (2012) A mini review of pyrimidine and fused pyrimidine marketed drugs. Res Pharm 2(4):01-09

5. Xu Y, Hao SY, Zhang XJ, Li WB, Qiao XP, Wang ZX, Chen SW (2020) Discovery of novel 2, 4-disubstituted pyrimidines as aurora kinase inhibitors. Bioorg Med Chem Lett 30(3):126885 https://doi.org/10.1016/j.bmcl.2019.12 6885

6. Hu G, Wang C, Xin X, Li S, Li Z, Zhao Y, Gong P (2019) Design, synthesis and biological evaluation of novel 2,4-diaminopyrimidine derivatives as potent antitumor agents. New J Chem 43(25):10190-10202 https://doi.org/10.1039/ C9NJ02154J

7. Kamal A, Dastagiri D, Ramaiah MJ, Reddy JS, Bharathi EV, Reddy MK, Sagar MV, Reddy TL, Pushpavalli SN, Pal-Bhadra M (2011) Synthesis and apoptosis inducing ability of new anilino substituted pyrimidine sulfonamides as potential anticancer agents. Eur J Med Chem 46(12):5817-5824 https://doi. org/10.1016/j.ejmech.2011.09.039

8. Reddy OS, Suryanarayana CV, Narayana K, Anuradha V, Babu BH (2015) Synthesis and cytotoxic evaluation for some new 2, 5-disubstituted pyrimidine derivatives for anticancer activity. Med Chem Res 24(5):17771788 https://doi.org/10.1007/s00044-014-1276-6

9. Mule SNR, Nurbhasha S, Kolla JN, Jadav SS, Jayaprakash V, Bhavanam LR, Bollikolla HB (2016) Synthesis, biological screening and molecular docking studies of novel 4, 6-pyrimidine derivatives as EGFR-TK inhibitors. Med Chem Res 25(11):2534-2546 https://doi.org/10.1007/s00044-016-1668-x

10. Qin WW, Sang CY, Zhang LL, Wei W, Tian HZ, Liu HX, Chen SW, Hui L (2015) Synthesis and biological evaluation of 2, 4-diaminopyrimidines as selective aurora A kinase inhibitors. Eur J Med Chem 95:174-184 https://doi.org/10.1 016/j.ejmech.2015.03.044

11. Kraljević TG, Klika M, Kralj M, Martin-Kleiner I, Jurmanović S, Milić A, Padovan J, Raić-Malić S (2012) Synthesis, cytostatic activity and ADME properties of C5 substituted and $\mathrm{N}$-acyclic pyrimidine derivatives. Bioorg Med Chem Lett 22(1):308-312 https://doi.org/10.1016/j.bmcl.2011.11.009

12. Weinberg LR, Albom MS, Angeles TS, Husten J, Lisko JG, McHugh RJ, Milkiewicz KL, Murthy S, Ott GR, Theroff JP, Tripathy R (2011) Fused bicyclic derivatives of 2,4-diaminopyrimidine as C-Met inhibitors. Bioorg Med Chem Lett 21(1):164-167 https://doi.org/10.1016/j.bmcl.2010.11.045 
13. Kahriman N, Serdaroğlu V, Peker K, Aydın A, Usta A, Fandaklı S, Yaylı N (2019) Synthesis and biological evaluation of new 2, 4, 6-trisubstituted pyrimidines and their N-alkyl derivatives. Bioorg Chem 83:580-594 https:// doi.org/10.1016/j.bioorg.2018.10.068

14. Cheremnykh KP, Savelyev VA, Pokrovskii MA, Baev DS, Tolstikova TG, Pokrovskii AG, Shults EE (2019) Design, synthesis, cytotoxicity, and molecular modeling study of 2, 4, 6-trisubstituted pyrimidines with anthranilate ester moiety. Med Chem Res 28(4):545-558 https://doi.org/10.1007/s00044-019-02314-8

15. Omar AM, Abd El Razik HA, Hazzaa AA, El-Attar MA, El Demellawy MA, Abdel Wahab AE, El Hawash SA (2019) New pyrimidines and triazolopyrimidines as antiproliferative and antioxidants with cyclooxygenase-1/2 inhibitory potential. Future Med Chem 11(13):15831603 https://doi.org/10.4155/fmc-2018-0285

16. Kumar B, Sharma P, Gupta VP, Khullar M, Singh S, Dogra N, Kumar V (2018) Synthesis and biological evaluation of pyrimidine bridged combretastatin derivatives as potential anticancer agents and mechanistic studies. Bioorg Chem 78:130-140 https://doi.org/10.1016/j.ejmech.2017.12.082

17. Long L, Luo Y, Hou ZJ, Ma HJ, Long ZJ, Tu ZC, Huang L, Liu Q, Lu G (2018) Synthesis and biological evaluation of aurora kinases inhibitors based on $\mathrm{N}$ trisubstituted pyrimidine scaffold. Eur J Med Chem 145:805-812

18. Shao KP, Zhang XY, Chen PJ, Xue DQ, He P, Ma LY, Zheng JX, Zhang QR, Liu HM (2014) Synthesis and biological evaluation of novel pyrimidinebenzimidazol hybrids as potential anticancer agents. Bioorg Med Chem Lett 24(16):3877-3881 https://doi.org/10.1016/j.bmcl.2014.06.050

19. Shao H, Shi S, Huang S, Hole AJ, Abbas AY, Baumli S, Liu X, Lam F, Foley DW, Fischer PM, Noble M (2013) Substituted 4-(thiazol-5-yl)-2-(phenylamino) pyrimidines are highly active CDK9 inhibitors: synthesis, X-ray crystal structures, structure-activity relationship, and anticancer activities. J Med Chem 56(3):640-659 https://doi.org/10.1021/jm301475f

20. Khanage SG, Raju SA, Mohite PB, Pandhare RB (2012) Synthesis and pharmacological evaluation of some new pyrimidine derivatives containing 1, 2, 4-triazole. Adv Pharm Bull 2(2):213.https://dx.doi.org/10.5681\%2Fapb.2 012.033-222. https://doi.org/10.5681/apb.2012.033

21. Sridhar S, Prasad YR, Dinda SC (2011) Synthesis and anticancer activity of some novel pyrimidine derivatives. Int J Pharm Sci Res 2(10):2562-2565

22. Rashid M, Husain A, Shaharyar M, Mishra R, Hussain A, Afzal O (2014) Design and synthesis of pyrimidine molecules endowed with thiazolidin-4-one as new anticancer agents. Eur J Med Chem 83:630-645 https://doi.org/10.101 6/j.ejmech.2014.06.033

23. Luo G, Tang Z, Lao K, Li X, You Q, Xiang H (2018) Structure-activity relationships of 2, 4-disubstituted pyrimidines as dual ERaNEGFR-2 ligands with anti-breast cancer activity. Eur J Med Chem 150:783-795. https://doi. org/10.7324/JAPS.2017.71104

24. Yousif MNM, El-Sayed WA, Abbas HA, Awad HM, Yousif NM (2017) Anticancer activity of new substituted pyrimidines, their thioglycosides and thiazolopyrimidine derivatives. J Appl Pharm Sci 7(11):021-032. https://doi. org/10.7324/JAPS.2017.71104

25. Abdel HT, Mohsen GAS, Mahmoud AE, Ali MM, El Diwani HI (2019) New 2, 4-disubstituted-2-thiopyrimidines as VEGFR-2 inhibitors: design, synthesis, and biological evaluation. Arch Pharm 352(11):1900089 https://doi.org/10.1 002/ardp.201900089

26. Ma LY, Wang B, Pang LP, Zhang $M$, Wang SQ, Zheng YC, Shao KP, Xue DQ, Liu HM (2015) Design and synthesis of novel 1, 2, 3-triazole-pyrimidineurea hybrids as potential anticancer agents. Bioorg Med Chem Lett 25(5): 1124-1128 https://doi.org/10.1016/j.bmcl.2014.12.087

27. Ma LY, Zheng YC, Wang SQ, Wang B, Wang ZR, Pang LP, Zhang M, Wang JW, Ding L, Li J, Wang C (2015) Design, synthesis, and structure-activity relationship of novel LSD1 inhibitors based on pyrimidine-thiourea hybrids as potent, orally active antitumor agents. J Med Chem 58(4):1705-1716 https://doi.org/10.1021/acs.jmedchem.5b00037

28. Ma LY, Pang LP, Wang B, Zhang M, Hu B, Xue DQ, Shao KP, Zhang BL, Liu Y, Zhang E, Liu HM (2014) Design and synthesis of novel 1, 2, 3-triazolepyrimidine hybrids as potential anticancer agents. Eur J Med Chem 86:368380 https://doi.org/10.1016/j.ejmech.2014.08.010

29. Taher AT, Helwa AA (2012) Synthesis, antitumor and antimicrobial testing of some new thiopyrimidine analogues. Chem Pharm Bull 60(10):12-00557 https://doi.org/10.1248/cpb.c12-00557

30. Rostom SA, Badr MH, Abd El Razik HA, Ashour HM, Abdel Wahab AE (2011) Synthesis of some pyrazolines and pyrimidines derived from polymethoxychalcones as anticancer and antimicrobial agents. Arch Pharm 344(9):572-587 https://doi.org/10.1002/ardp.201100077
31. El-Sayed WA, Mohamed AM, Khalaf HS, EL-Kady DS, Al-Manawaty M (2017) Synthesis, docking studies and anticancer activity of new substituted pyrimidine and triazolopyrimidine glycosides. J Appl Pharm Sci 7(09):001011. https://doi.org/10.7324/JAPS.2017.70901

32. Hassan AY, Saleh NM, Kadh MS, Abou Amra ES (2020) New fused pyrazolopyrimidine derivatives; heterocyclic styling, synthesis, molecular docking and anticancer evaluation. J Heterocyclic Chem 57(7):2704-2721 https://doi.org/10.1002/jhet.3979

33. Hassan AS, Mady MF, Awad HM, Hafez TS (2017) Synthesis and antitumor activity of some new pyrazolo [1, 5-a] pyrimidines. Chin Chem Lett 28(2): 388-393 https://doi.org/10.1016/j.cclet.2016.10.022

34. Hassan AS, Moustafa GO, Awad HM (2017) Synthesis and in vitro anticancer activity of pyrazolo [1, 5-a] pyrimidines and pyrazolo [3, 4-d][1, 2, 3] triazines. Synth Commun 47(21):1963-1972 https://doi.org/10.1080/00397911.2017.13 58368

35. Kumar AA, Bodke YD, Lakra PS, Sambasivam G, Bhat KG (2017) Design, synthesis and anti-cancer evaluation of a novel series of pyrazolo [1, 5-a] pyrimidine substituted diamide derivatives. Med Chem Res 26(4):714-744 https://doi.org/10.1007/s00044-016-1770-0

36. Bagul C, Rao GK, Makani VK, Tamboli JR, Pal-Bhadra M, Kamal A (2017) Synthesis andbiological evaluation of chalcone-linked pyrazolo [1, 5-a] pyrimidines as potential anticancer agents. MedChemComm. 8(9):1810 1816. https://doi.org/10.1039/C7MD00193B

37. Zhao M, Ren H, Chang J, Zhang D, Yang Y, He Y, Qi C, Zhang H (2016) Design and synthesis of novel pyrazolo [1, 5-a] pyrimidine derivatives bearing nitrogen mustard moiety and evaluation of their antitumor activity in vitro and in vivo. Eur J Med Chem 119:183-196 https://doi.org/10.1016/j. ejmech.2016.04.068

38. Kaping S, Kalita U, Sunn M, Singha LI, Vishwakarma JN (2016) A facile, regioselective synthesis of pyrazolo [1,5-a] pyrimidine analogs in the presence of KHSO 4 in aqueous media assisted by ultrasound and their anti-inflammatory and anti-cancer activities. Monatsh Chem 147(7):12571276 https://doi.org/10.1007/s00706-015-1638-x

39. Hassan AS, Hafez TS, Osman SA, Ali MM (2015) Synthesis and in vitro cytotoxic activity of novel pyrazolo [1,5- a] pyrimidines and related Schiff bases. Turk J Chem 39(5):1 102-1113. https://doi.org/10.3906/kim-1504-12

40. Phillipson L, Segal DH, Nero TL, Parker MW, San Wan S, de Silva M, Guthridge MA, Wei AH, Burns CJ (2015) Discovery and SAR of novel pyrazolo [1, 5-a] pyrimidines as inhibitors of CDK9. Bioorg Med Chem 23(19):6280-6296 https://doi.org/10.1016/j.bmc.2015.08.035

41. Kamal A, Tamboli JR, Nayak VL, Adil SF, Vishnuvardhan MV, Ramakrishna S (2013) Synthesis of pyrazolo [1, 5-a] pyrimidine linked aminobenzothiazole conjugates as potential anticancer agents. Bioorg Med Chem Lett 23(11): 3208-3215 https://doi.org/10.1016/j.bmcl.2013.03.129

42. Wang X, Magnuson S, Pastor R, Fan E, Hu H, Tsui V, Deng W, Murray J, Steffek M, Wallweber H, Moffat J (2013) Discovery of novel pyrazolo [1, 5-a] pyrimidines as potent pan-Pim inhibitors by structure-and property-based drug design. Bioorg Med Chem Lett 23(11):3149-3153 https://doi.org/10.101 6/j.bmcl.2013.04.020

43. Kumar A, Ahmad I, Chhikara BS, Tiwari R, Mandal D, Parang K (2011) Synthesis of 3-phenylpyrazolopyrimidine-1, 2, 3-triazole conjugates and evaluation of their Src kinase inhibitory and anticancer activities. Bioorg Med Chem Lett 21(5):1342-1346 https://doi.org/10.1016/j.bmcl.2011.01.047

44. Gaonkar S, Savanur MA, Nadaf AA, Najare MS, Mantur S, Garbhagudi M, MullaSI KIA (2020) Novel pyrazolo [3, 4-d] pyrimidine derivatives inhibit human cancer cellproliferation and induce apoptosis by ROS generation. Arch Pharm 353(4):1900296 https://doi.org/10.1002/ardp.201900296

45. Cherukupalli S, Chandrasekaran B, Aleti RR, Sayyad N, Hampannavar GA, Merugu SR, Rachamalla HR, Banerjee R, Karpoormath R (2019) Synthesis of 4, 6-disubstituted pyrazolo[3, 4-d] pyrimidine analogues: cyclin-dependent kinase 2 (CDK2) inhibition, molecular docking and anticancer evaluation. J Mol Struct 1176:538-551 https://doi.org/10.1016/j.molstruc.2018.08.104

46. Cherukupalli S, Chandrasekaran B, Kryštof V, Aleti RR, Sayyad N, Merugu SR, Kushwaha ND, Karpoormath R (2018) Synthesis, anticancer evaluation, and molecular docking studies of some novel 4, 6-disubstituted pyrazolo [3, 4-d] pyrimidines as cyclin-dependent kinase 2 (CDK2) inhibitors. Bioorg Chem 79:46-59 https://doi.org/10.1016/j.bioorg.2018.02.030

47. Yoon JS, Jarhad DB, Kim G, Nayak A, Zhao LX, Yu J, Kim HR, Lee JY, Mulamoottil VA, Chandra G, Byun WS (2018) Design, synthesis and anticancer activity of fluorocyclopentenyl-purines and-pyrimidines. Eur J Med Chem 155:406-417 https://doi.org/10.1016/j.ejmech.2018.06.003 
48. Lee HJ, Pham PC, Hyun SY, Baek B, Kim B, Kim Y, Min HY, Lee J, Lee HY (2018) Development of a 4-aminopyrazolo [3, 4-d] pyrimidine-based dual IGF1R/Srcinhibitoras a novel anticancer agent with minimal toxicity. Mol Cancer (1):1-6 https://doi.org/10.1186/s12943-018-0802-4

49. Wang C, Liu H, Song Z, Ji Y, Xing L, Peng X, Wang X, Ai J, Geng M, Zhang A (2017) Synthesis and structure-activity relationship study of pyrazolo [3, 4-d] pyrimidines as tyrosine kinase RET inhibitors. Bioorg Med Chem Lett 27(11): 2544-2548 https://doi.org/10.1016/j.bmcl.2017.03.088

50. Vignaroli G, lovenitti G, Zamperini C, Coniglio F, Calandro P, Molinari A, FallacaraAL SA, Calgani A, Colecchia D, Mancini A (2017) Prodrugs of Pyrazolo [3, 4-d]pyrimidines: from library synthesis to evaluation as potential anticancer agents in an orthotopic glioblastoma model. J Med Chem 60(14): 6305-6320 https://doi.org/10.1021/acs.jmedchem.7b00637

51. Abdelgawad MA, Bakr RB, Alkhoja OA, Mohamed WR (2016) Design, synthesis and antitumor activity of novel pyrazolo [3, 4-d] pyrimidine derivatives as EGFR-TK inhibitors. Bioorg Chem 66:88-96 https://doi.org/10.1 016/j.bioorg.2016.03.011

52. Abdel-Latif E, Abdel-Fattah S, Gaffer HE, Etman HA (2016) Synthesis and antitumor activity of some new pyrazolo $[3,4-d]$ pyrimidine and pyrazolo [3, 4-b] pyridine derivatives. Egypt J Basic Appl Sci 3(1):118-124 https://doi. org/10.1016/j.ejbas.2015.11.001

53. Rahmouni A, Souiei S, Belkacem MA, Romdhane A, Bouajila J, Jannet HB (2016) Synthesis and biological evaluation of novel pyrazolopyrimidines derivatives as anticancer and anti-5-lipoxygenase agents. Bioorg Chem 66: 160-168 https://doi.org/10.1016/j.bioorg.2016.05.001

54. He HY, Zhao JN, Jia R, Zhao YL, Yang SY, Yu LT, Yang L (2011) Novel pyrazolo [3, 4-d]pyrimidine derivatives as potential antitumor agents: exploratory synthesis, preliminary structure-activity relationships, and in vitro biological evaluation. Molecules. 16(12):10685-10694 https://doi.org/10.33 90/molecules 161210685

55. Radi M, Dreassi E, Brullo C, Crespan E, Tintori C, Bernardo V, Valoti M, Zamperini C, Daigl H, Musumeci F, Carraro F, Naldini A, Filippi I, Maga G, Schenone S, Botta M (2013) Design, synthesis, and biological evaluation of pyrazolo[3,4-11 d]pyrimidines active in vivo on the Bcr-Abl T315I mutant. J Med Chem 56(13):5382-5394 https://doi.org/10.1021/jm400233w

56. Radi M, Dreassi E, Brullo C, Crespan E, Tintori C, Bernardo V, Valoti M, Zamperini C, Daigl H, Musumeci F, Carraro F (2011) Design, synthesis, biological activity, and ADME properties of pyrazolo [3, 4-d] pyrimidines active in hypoxic human leukemia cells: a lead optimization study. J Med Chem 54(8):2610-2626 https://doi.org/10.1021/jm1012819

57. AbdEl Hamid MK, Mihovilovic MD, El-Nassan HB (2012) Synthesis of novel pyrazolo [3, 4-d] pyrimidine derivatives as potential anti-breast cancer agents. Eur J Med Chem 57:323-328 https://doi.org/10.1016/j.ejmech.2012. 09.031

58. Huang YY, Wang LY, Chang CH, Kuo YH, Kaneko K, Takayama H, Kimura M, Juang SH, Wong FF (2012) One-pot synthesis and antiproliferative evaluation of pyrazolo [3, 4-d] pyrimidine derivatives. Tetrahedron 68(47): 9658-9664 https://doi.org/10.1016/j.tet.2012.09.054

59. Yallappa GN, Nagaraja D, Chandrashekhar U (2019) Green Synthesis of pyrazolo $[3,4]$-pyrimidine-thiones by using lonic liquid 2-methylimidazolium-oxalate as potent Ehrlich ascites carcinoma receptor antagonists Asian J. Pharm Clin Res 12(9):287-287 https://doi.org/10.22159/a jpcr.2019.v12i9.34661

60. Rashad AE, Mahmoud AE, Ali MM (2011) Synthesis and anticancer effects of some novel pyrazolo $[3,4-d]$ pyrimidine derivatives by generating reactive oxygen species in human breast adenocarcinoma cells. Eur J Med Chem 46(4):1019-1026 https://doi.org/10.1016/j.ejmech.2011.01.013

61. Jorda R, Havlíček L, Šturc A, TuŠková D, Daumová L, Alam M, Škerlová J, Nekardová M, Peřina M, PospíšilT ŠJ (2019) 3, 5, 7-Substituted pyrazolo [4, 3d] pyrimidine inhibitors of cyclin-dependent kinases and their evaluation in lymphoma models. J Med Chem 62(9):4606-4623 https://doi.org/10.1021/a cs.jmedchem.9b00189

62. Jorda R, Havlícek L, McNae IW, Walkinshaw MD, Voller J, Šturc A, Navrátilová J, Kuzma M, Mistrík M, Bártek J, Strnad M (2011) Pyrazolo [4, 3-d] pyrimidine bioisostere of roscovitine: evaluation of a novel selective inhibitor of cyclindependent kinases with antiproliferative activity. J Med Chem 54(8):29802993 https://doi.org/10.1021/jm200064p

63. Hafez HN, El-Gazzar AR, Al-Hussain SA (2016) Novel pyrazole derivatives with oxa/thiadiazolyl, pyrazolyl moieties and pyrazolo [4, 3-d]-pyrimidine derivatives as potential antimicrobial and anticancer agents. Bioorg Med Chem Lett 26(10):2428-2433 https://doi.org/10.1016/j.bmcl.2016.03.117
64. Vymětalová L, Havlíček L, Šturc A, Skrášková Z, Jorda R, Pospišil T, Strnad M, Kryštof V (2016) 5-Substituted 3-isopropyl-7-[4-(2-pyridyl) benzyl] amino-1 (2) H-pyrazolo [4, 3-d] pyrimidines with anti-proliferativeactivity as potent and selective inhibitors of cyclin-dependent kinases. Eur J Med Chem 110:291301 https://doi.org/10.1016/j.ejmech.2016.01.011

65. Řezníčková E, Weitensteiner S, Havliček L, Jorda R, Gucký T, Berka K, Bazgier V, Zahler S, Kryštof V, Strnad M (2015) Characterization of a pyrazolo [4, 3-d] pyrimidine inhibitor of cyclin dependent kinases 2 and 5 and aurora A with pro-apoptotic and anti-angiogenic activity in vitro. Chem Biol Drug Des 86(6):1528-1540 https://doi.org/10.1111/cbdd.12618

66. Reddy GL, Guru SK, Srinivas M, Pathania AS, Mahajan P, Nargotra A, Bhushan S, VishwakarmaRA SSD (2014) Synthesis of 5-substituted-1H-pyrazolo [4, 3-d] pyrimidin-7 (6H)-one analogs and theirbiological evaluation as anticancer agents: mTOR inhibitors. Eur J Med Chem 80:201-208 https://doi.org/10.101 6/j.ejmech.2014.04.051

67. Wang R, Chen Y, Zhao X, Yu S, Yang B, Wu T, Guo J, Hao C, Zhao D, Cheng M (2019) Design, synthesis and biological evaluation of novel $7 \mathrm{H}$-pyrrolo [2, 3-d] pyrimidinederivatives as potential FAK inhibitors and anticancer agents. Eur J Med Chem 183:111716 https://doi.org/10.1016/j.ejmech.2019.111716

68. Dincer S, Cetin KT, Onay-Besikci A, Ölgen S (2013) Synthesis, biological evaluation and docking studies of new pyrrolo [2, 3-d] pyrimidine derivatives as Src family-selective tyrosine kinase inhibitors. J Enzyme Inhib Med Chem 28(5):1080-1087 https://doi.org/10.3109/14756366.2012.715288

69. Wang LX, Liu X, Xu S, Tang Q, Duan Y, Xiao Z, Zhi J, Jiang L, Zheng P, Zhu W (2017) Discovery of novel pyrrolo-pyridine/pyrimidine derivatives bearing pyridazinone moiety as c-Met kinase inhibitors. Eur J Med Chem 141:538551 https://doi.org/10.1016/j.ejmech.2017.10.027

70. Ghorab MM, Alsaid MS, Nissan YM (2013) Anti breast cancer of some novel pyrrolo and pyrrolopyrimidine derivatives bearing a biologically active sulfonamide moiety. Life Sci J 10(4):2170-2183

71. Yang F, Yu LZ, Diao PC, Jian XE, Zhou MF, Jiang CS, You WW, Ma WF, Zhao PL (2019) Novel [1, 2, 4] triazolo [1, 5-a] pyrimidine derivatives as potent antitubulin agents: design, multicomponent synthesis and antiproliferative activities. Bioorg Chem 92:103260 https://doi.org/10.1016/j.bioorg.2019.1032 60

72. Gilandoust M, Harsha KB, Mohan CD, Raquib AR, Rangappa S, Pandey V, Lobie PE, Rangappa KS (2018) Synthesis, characterization and cytotoxicity studies of 1, 2, 3-triazoles and 1, 2, 4-triazolo [1, 5-a] pyrimidines in human breast cancer cells. Bioorg Med Chem Lett 28(13):2314-2319 https://doi. org/10.1016/j.bmcl.2018.05.020

73. Arenas-González A, Mendez-Delgado LA, Merino-Montiel P, Padrón JM, Montiel-Smith S, Vega-Báez JL, Meza-Reyes S (2016) Synthesis of monomeric and dimeric steroids containing $[1,2,4]$ triazolo $[1,5-a]$ pyrimidines. Steroids 116:13-19 https://doi.org/10.1016/j.steroids.2016.09.014

74. Huang LH, Zheng YF, Lu YZ, Song CJ, Wang YG, Yu B, Liu HM (2012) Synthesis and biological evaluation of novel steroidal [17, 16-d][1, 2, 4] triazolo [1, 5-a] pyrimidines. Steroids. 77(6):710-715 https://doi.org/10.1016/j. steroids.2012.03.002

75. Li ZH, Liu XQ, Geng PF, Suo FZ, Ma JL, Yu B, Zhao TQ, Zhou ZQ, Huang CX, Zheng YC, Liu HM (2017) Discovery of [1, 2, 3] Triazolo [4, 5-d] pyrimidine derivatives as novel LSD1 inhibitors. ACS Med Chem Lett 8(4):384-389 https://doi.org/10.1021/acsmedchemlett.6b00423

76. Li ZH, Yang DX, Geng PF, Zhang J, Wei HM, Hu B, Guo Q, Zhang XH, Guo WG, Zhao B, Yu B (2016) Design, synthesis and biological evaluation of [1, 2, 3] triazolo [4, 5-d] pyrimidine derivatives possessing a hydrazone moiety as antiproliferative agents. Eur J Med Chem 124:967-980 https://doi.org/10.101 6/j.ejmech.2016.10.022

77. Gregorić T, Sedić M, Grbčić P, Paravić AT, Pavelić SK, Cetina M, Vianello R, RaićMalić S (2017) Novel pyrimidine-2, 4-dione-1, 2, 3-triazole and furo [2, 3-d] pyrimidine-2-one-1, 2, 3-triazole hybrids as potential anti-cancer agents: synthesis, computational and X-ray analysis and biological evaluation. Eur J Med Chem 125:1247-1267 https://doi.org/10.1016/j.ejmech.2016.11.028

78. Khazir J, Mir BA, Chashoo G, Pilcher L, Riley D (2020) Synthesis and anticancer activity of N-9-and N-7-substituted 1, 2, 3 triazole analogues of 2, 6-di-substituted purine. Med Chem Res 29(1):33-45 https://doi.org/10.1007/ s00044-019-02456-9

79. Aeluri R, Alla M, Polepalli S, Jain N (2015) Synthesis and antiproliferative activity of imidazo [1, 2-a] pyrimidine Mannich bases. Eur J Med Chem 100: 18-23 https://doi.org/10.1016/j.ejmech.2015.05.037

80. Conejo-García A, García-Rubiño ME, Marchal JA, Núñez MC, Ramírez A, Cimino S, García MÁ, Aránega A, Gallo MA, Campos JM (2011) Synthesis and 
anticancer activity of (RS)-9-(2, 3-dihydro-1, 4-benzoxaheteroin-2-ylmethyl)9H-purines. Eur J Med Chem 46(9):3795-3801 https://doi.org/10.1016/j. ejmech.2011.05.046

81. Kumar GS, Dev GJ, Kumar NR, Swaroop DK, Chandra YP, Kumar CG, Narsaiah B (2015) Synthesis of novel pyrido [1, 2-a] pyrimidine-3-carboxamide derivatives and their anticancer activity. Chem Pharm Bull 63(8):584-590 https://doi.org/10.1248/cpb.c15-00219

82. Kumar RN, Poornachandra Y, Nagender P, Mallareddy G, Kumar NR, Ranjithreddy P, Kumar CG, Narsaiah B (2016) Synthesis of novel trifluoromethyl substituted furo [2, 3-b] pyridine and pyrido [3', 2': 4, 5] furo [3, 2-d] pyrimidine derivatives as potential anticancer agents. Eur J Med Chem 108:68-78 https://doi.org/10.1016/j.ejmech.2015.11.007

83. AbedelRehim EM, AbdEllatif M (2018) Synthesis of some novel pyrido [2, 3d] pyrimidine and pyrido $[3,2-e][1,3,4]$ triazolo and tetrazolo $[1,5-c]$ pyrimidine derivatives as potential antimicrobial and anticancer agents. $J$ Heterocycle Chem 55(2):419-430 https://doi.org/10.1002/jhet.3058

84. Fares M, Abou-Seri SM, Abdel-Aziz HA, Abbas SE, Youssef MM, Eladwy RA (2014) Synthesis and antitumor activity of pyrido [2, 3-d] pyrimidine and pyrido $[2,3-d][1,2,4]$ triazolo $[4,3-a]$ pyrimidine derivatives that induce apoptosis through G1 cell-cycle arrest. Eur J Med Chem 83:155-166 https:// doi.org/10.1016/j.ejmech.2014.06.027

85. Palop JA, Plano D, Moreno E, Sanmartín C (2014) Novel quinazoline and pyrido [2, 3-d] pyrimidine derivatives and their hydroselenite salts as antitumoral agents. Arkivoc II:187-206

86. Elansary AK, Moneer AA, Kadry HH, Gedawy EM (2014) Synthesis and antitumour activity of certain pyrido [2,3-d] pyrimidine and 1, 8naphthyridine derivatives. J Chem Res 38(3):147-153.https://doi.org/10.31 84\%2F174751914X13910886393992. https://doi.org/10.3184/174751914X13 910886393992

87. Moreno E, Plano D, Lamberto I, Font M, Encío I, Palop JA, Sanmartín C (2012) Sulfur and selenium derivatives of quinazoline and pyrido [2, 3-d] pyrimidine: synthesis and study of their potential cytotoxic activity in vitro. Eur J Med Chem 47(1):283-298.https://doi.org/10.1016/j.ejmech.2011.10.056

88. Kumar RN, Dev GJ, Ravikumar N, Swaroop DK, Debanjan B, Bharath G, Narsaiah B, Jain SN, Rao AG (2016) Synthesis of novel triazole/isoxazole functionalized 7-(trifluoromethyl) pyrido [2, 3-d] pyrimidine derivatives as promising anticancer and antibacterial agents. Bioorg Med Chem Lett 26(12):2927-2930 https://doi.org/10.1007/s1 1030-018-9859-7

89. Hou J, Wan S, Wang G, Zhang T, Li Z, Tian Y, Yu Y, Wu X, Zhang J (2016) Design, synthesis, anti-tumor activity, and molecular modeling of quinazoline and pyrido [2, 3-d] pyrimidine derivatives targeting epidermal growth factor receptor. Eur J Med Chem 118:276-289 https://doi.org/10.101 6/j.ejmech.2016.04.026

90. Kurumurthy C, Rao PS, Rao PS, Narsaiah B, Velatooru LR, Pamanji R, Rao JV (2011) Synthesis of novel alkyltriazole tagged pyrido [2, 3-d] pyrimidine derivatives and their anticancer activity. Eur J Med Chem 46(8):3462-3468 https://doi.org/10.1016/j.ejmech.2011.05.011

91. Wei L, Malhotra SV (2012) Synthesis and cytotoxicity evaluation of novel pyrido [3, 4-d] pyrimidine derivatives as potential anticancer agents. Med Chem Commun 3(10):1250-1257 https://doi.org/10.1039/C2MD20097J

92. Kumar NR, Poornachandra Y, Swaroop DK, Dev GJ, Kumar CG, Narsaiah B (2016) Synthesis of novel ethyl 2, 4-disubstituted 8-(trifluoromethyl) pyrido $\left[2^{\prime}, 3^{\prime}: 3,4\right]$ pyrazolo [1, 5-a] pyrimidine-9-carboxylate derivatives as promising anticancer agents. Bioorg.Med.Chem.Lett. 26(21):5203-5206 https://doi.org/10.1016/j.bmcl.2016.09.062

93. Elzahabi HS, Nossier ES, Khalifa NM, Alasfoury RA, El-Manawaty MA (2018) Anticancer evaluation and molecular modeling of multi-targeted kinase inhibitors based pyrido [2, 3-d] pyrimidine scaffold. J Enzyme Inhib Med Chem 33(1):546-557 https://doi.org/10.1080/14756366.2018.1437729

94. Abbas SE, Gawad NM, George RF, Akar YA (2013) Synthesis, antitumor and antibacterial activities of some novel tetrahydrobenzo $[4,5]$ thieno $[2,3-d]$ pyrimidine derivatives. Eur J Med Chem 65:195-204 https://doi.org/10.1016/ j.ejmech.2013.04.055

95. Guo YC, Li J, Ma JL, Yu ZR, Wang HW, Zhu WJ, Liao XC, Zhao YF (2015) Synthesis and antitumor activity of a-aminophosphonate derivatives containing thieno [2, 3-d] pyrimidines. Chin Chem Lett 26(6):755-758 https://doi.org/10.1016/j.cclet.2015.03.026

96. Mavrova AT, Dimov S, Yancheva D, Rangelov M, Wesselinova D, Tsenov JA (2016) Synthesis, anticancer activity and photostability of novel 3-ethyl-2mercapto-thieno [2, 3-d] pyrimidin-4 (3H)-ones. Eur J Med Chem 123:69-79 https://doi.org/10.1016/j.ejmech.2016.07.022
97. Elmetwally SA, Saied KF, Eissa IH, Elkaeed EB (2019) Design, synthesis and anticancer evaluation of thieno [2, 3-d] pyrimidine derivatives as dual EGFR/ HER2 inhibitors and apoptosis inducers. Bioorg Chem 88:102944 https://doi. org/10.1016/j.bioorg.2019.102944

98. El-Metwally SA, Khalil AK, El-Sayed WM (2020) Design, molecular modeling and anticancer evaluation of thieno [2,3-d] pyrimidine derivatives as inhibitors of topoisomerase II. Bioorg Chem 94:103492 https://doi.org/10.101 6/j.bioorg.2019.103492

99. Habib NS, Soliman R, El-Tombary AA, El-Hawash SA, Shaaban OG (2013) Synthesis and biological evaluation of novel series of thieno [2, 3-d] pyrimidine derivatives as anticancer and antimicrobial agents. Med Chem Res 22(7):3289-3308 https://doi.org/10.1007/s00044-012-0324-3

100. Fouad MM, El-Bendary ER, Shehata IA, El-Kerdawy MM (2018) Synthesis and in vitro antitumor evaluation of some new thiophenes and thieno $[2,3-d]$ pyrimidine derivatives. Bioorg Chem 81:587-598 https://doi.org/10.1016/j. bioorg.2018.09.022

101. Saddik AA, Kamal El-Dean AM, El-Said WA, Hassan KM, Abbady MS (2018) Synthesis, antimicrobial, and anticancer activities of a new series of thieno [2, 3-d] pyrimidine derivatives. J Heterocyclic Chem 55(9):2111-2122 https:// doi.org/10.1002/jhet.3256

102. Kandeel MM, Mounir AA, Refaat HM, Kassab AE (2012) Synthesis of thieno $[2,3-d]$ pyrimidines, thieno $[2,3-d]$ triazinones and thieno $[2,3-e]$ diazepinones of anticipated anti-cancer activity. J Chem Res 36(2):105-110 https://doi.org/10.3184/2F174751912X13282020691270

103. Sharaky M, Kamel M, Aziz MA, Omran M, Rageh MM, Abouzid KA, Shouman SA (2020) Design, synthesis and biological evaluation of a new thieno [2, 3d] pyrimidine-based urea derivative with potential antitumor activity against tamoxifen sensitive and resistant breast cancer cell lines. J Enzyme Inhib Med Chem 35(1):1641-1656 https://doi.org/10.1080/14756366.2020.1804383

104. Pavase LS, Mane DV (2016) Synthesis and anticancer activities of novel (tetrahydrobenzo [4, 5] thieno [2, 3-d] pyrimidine-4-yl)-pyrolidine-2carboxylic acid derivatives. Med Chem Res 25(10):2380-2391 https://doi. org/10.1007/s00044-016-1692-x

105. Ghorab MM, Alsaid MS (2016) Anticancer activity of some novel thieno [2, 3-d] pyrimidine derivatives. Biomed.Res 27(1):110-115

106. Ramya PV, Thatikonda S, Angapelly S, Babu BN, Naidu VG, Kamal A (2018) Synthesis and biological evaluation of thieno [2, 3-d] pyrimidine-amides as potential anticancer agents. Chemistry Select 3(11):3101-3106 https://doi. org/10.1002/slct.201703061

107. Li J, Gu W, Bi X, Li H, Liao C, Liu C, Huang W, Qian H (2017) Design, synthesis, and biological evaluation of thieno [2, 3-d] pyrimidine derivatives as novel dual c-Met and VEGFR-2 kinase inhibitors. Bioorg Med Chem 25(24):6674-6679 https://doi.org/10.1016/j.bmc.2017.11.010

108. Kaliraj S, Jeyalakshmi R, Kathiravan MK (2020) Synthesis, cytotoxic activity and molecular docking studies of new condensed thieno $[2,3-\mathrm{d}]$ pyrimidines as antitumor agents. Pharm Chem J 54(3):258-267 https://doi. org/10.1007/s11094-020-02188-w

109. Kassab AE, Gedawy EM, El-Malah AA, Abdelghany TM, Abdel-Bakky MS (2016) Synthesis, anticancer activity, effect on cell cycle profile, and apoptosis-inducing ability of novel hexahydrocyclooctathieno [2, 3-d] pyrimidine derivatives. Chem Pharm Bull 64(5):490-496 https://doi.org/1 0.1248/cpb.c15-00277

110. Kassab AE, Gedawy EM (2013) Synthesis and anticancer activity of novel 2pyridyl hexahyrocyclooctathieno [2, 3-d] pyrimidine derivatives. Eur J Med Chem 63:224-230 https://doi.org/10.1016/j.ejmech.2013.02.011

111. Hafez HN, Alsalamah SA, El-Gazzar AR (2017) Synthesis of thiophene and Nsubstituted thieno [3, 2-d] pyrimidine derivatives as potent antitumor and antibacterial agents. Acta Pharma 67(3):275-292 https://doi.org/10.1515/a cph-2017-0028

112. Zhu W, Zhai X, Fu Q, Guo F, Bai M, Wang J, Wang H, Gong P (2012) Design, synthesis and anticancer activity of 4-morpholinothieno [3, 2-d] pyrimidine derivatives bearing arylmethylene hydrazine moiet. Chem Pharm Bull 60(8): 1037-1045 https://doi.org/10.1248/cpb.c12-00342

113. Liu Z, Wu S, Wang Y, Li R, Wang J, Wang L, Zhao Y, Gong P (2014) Design, synthesis and biological evaluation of novel thieno [3, 2-d] pyrimidine derivatives possessing diarylsemicarbazone scaffolds as potent antitumor agents. Eur J Med Chem 87:782-793 https://doi.org/10.1016/j.ejmech.2014.10.022

114. Liu Z, Wang Y, Lin H, Zuo D, Wang L, Zhao Y, Gong P (2014) Design, synthesis and biological evaluation of novel thieno [3, 2-d] pyrimidine derivatives containing diaryl urea moiety as potent antitumor agents. Eur J Med Chem 85:215-227 https://doi.org/10.1016/j.ejmech.2014.07.099 
115. Wang R, Yu S, Zhao X, Chen Y, Yang B, Wu T, Hao C, Zhao D, Cheng M (2020) Design, synthesis, biological evaluation and molecular docking study of novel thieno [3, 2-d] pyrimidine derivatives as potent FAK inhibitors. Eur J Med Chem 188:112024 https://doi.org/10.1016/j.ejmech.2019.112024

116. Tan Q, Zhang Z, Hui J, Zhao Y, Zhu L (2014) Synthesis and anticancer activities of thieno [3, 2-d] pyrimidines as novel HDAC inhibitors. Bioorg Med Chem 22(1):358-365 https://doi.org/10.1016/j.bmc.2013.11.021

117. Kandeel MM, Refaat HM, Kassab AE, Shahin IG, Abdelghany TM (2015) Synthesis, anticancer activity and effects on cell cycle profile and apoptosis of novel thieno [2, 3-d] pyrimidine and thieno [3, 2-e] triazolo [4, 3-c] pyrimidine derivatives. Eur J Med Chem 90:620-632 https://doi.org/10.1016/ j.ejmech.2014.12.009

118. Kandeel MM, Mounir AA, Refaat HM, Kassab AE (2012) Synthesis of effective anticancer thieno [2, 3-d] pyrimidine-4-ones and thieno [3, 2-e] triazolo [4, 3-c] pyrimidines. Int J Pharm Pharm Sci 4(3):438-448

119. Lauria A, Abbate I, Patella C, Martorana A, Dattolo G, Almerico AM (2013) New annelatedthieno $[2,3-e][1,2,3]$ triazolo [1, 5-a] pyrimidines, with potent anticancer activity, designed through VLAK protocol. Eur J Med Chem 62:416-424 https://doi.org/10.1016/j.ejmech.2013.01.019

120. Lauria A, Patella C, Abbate I, Martorana A, Almerico AM (2013) An unexpected dimroth rearrangement leading to annelatedthieno [3, 2-d][1, 2, 3] triazolo [1, 5-a] pyrimidines with potent antitumor activity. Eur J Med Chem 65:381-388 https://doi.org/10.1016/.ejmech.2013.05.012

121. Nagarapu L, Vanaparthi S, Bantu R, Kumar CG (2013) Synthesis of novel benzo $[4,5]$ thiazolo $[1,2-a]$ pyrimidine-3-carboxylate derivatives and biological evaluation as potential anticancer agents. Eur J Med Chem 69: 817-822 https://doi.org/10.1016/.ejmech.2013.08.024

122. Sekhar T, Thriveni P, Venkateswarlu A, Daveedu T, Peddanna K, Sainath SB (2020) One-pot synthesis of thiazolo [3, 2-a] pyrimidine derivatives, their cytotoxic evaluation and molecular docking studies. Spectrochim Acta A Mol Biomol Spectrosc 231:118056 https://doi.org/10.1016/j.saa.2020.118056

123. Hassan GS, El-Messery SM, Abbas A (2017) Synthesis and anticancer activity of new thiazolo [3, 2-a] pyrimidines: DNA binding and molecular modeling study. Bioorg.Chem. 74:41-52 https://doi.org/10.1016/j.bioorg.2017.07.008

124. Al-Omary FA, Hassan GS, El-Messery SM, El-Subbagh HI (2012) Substituted thiazoles $V$. Synthesis and antitumor activity of novel thiazolo [2, 3-b] quinazoline and pyrido [4, 3-d] thiazolo [3, 2-a] pyrimidine analogues. Eur J Med Chem 47:65-72 https://doi.org/10.1016/j.ejmech.2011.10.023

125. Sakaka AJ, Arabia S (2011) Anticancer activities of some new synthesized thiazolo [3, 2-a] pyrido [4, 3-d] pyrimidine derivatives. AmJ Biochem Biotechnol 7(2):43-54

126. Singh B, Guru SK, Kour S, Jain SK, Sharma R, Sharma PR, Singh SK, Bhushan S, Bharate SB, Vishwakarma RA (2013) Synthesis, antiproliferative and apoptosis-inducing activity of thiazolo [5, 4-d] pyrimidine. Eur J Med Chem 70:864-874 https://doi.org/10.1016/j.ejmech.2013.10.039

127. Li ZH, Zhang J, Liu XQ, Geng PF, Ma JL, Wang B, Zhao TQ, Zhao B, Wei HM, Wang C, Fu DJ (2017) Identification of thiazolo [5, 4-d] pyrimidine derivatives as potent antiproliferative agents through the drug repurposing strategy. Eur J Med Chem 135:204-212 https://doi.org/10.1016/j.ejmech.201 7.04 .056

128. Li ZH, Liu XQ, Geng PF, Zhang J, Ma JL, Wang B, Zhao TQ, Zhao B, Zhang XH, Yu B, Liu HM (2017) Design, synthesis and antiproliferative activity of thiazolo [5, 4-d] pyrimidine derivatives through the atom replacement strategy. Eur J Med Chem 138:1034-1041 https://doi.org/10.1016/j.ejmech.2 017.07 .039

129. Flefel EM, El-Sayed WA, Mohamed AM, El-Sofany WI, Awad HM (2017) Synthesis and anticancer activity of new 1-thia-4-azaspiro [4.5] decane, their derived thiazolopyrimidineand 1, 3, 4-thiadiazole thioglycosides. Molecules 22(1):170 https://doi.org/10.3390/molecules22010170

130. Perupogu N, Kumar DR, Ramachandran D (2020) Anticancer activity of newly synthesized 1, 2, 4-oxadiazole linked 4-oxazolo [5, 4-d] pyrimidine derivatives. Chem Data Collect https://doi.org/10.1016/j.cdc.2020.100363

131. Deng YH, Xu D, Su YX, Cheng YJ, Yang YL, Wang XY, Zhang J, You QD, Sun LP (2015) Synthesis and biological evaluation of novel oxazolo [5, 4-d] pyrimidines as potent VEGFR-2 inhibitors. Chem Biodivers 12(4):528-537 https://doi.org/10.1002/cbdv.201400270

132. Liu J, Deng YH, Yang L, Chen Y, Lawali M, Sun LP, Liu Y (2015) CPU-12, a novel synthesized oxazolo [5, 4-d] pyrimidine derivative, showed superior anti-angiogenic activity. J Pharmacol Sci 129(1):9-17 https://doi.org/10.1016/ j.jphs.2015.06.001
133. Manasa K, Sidhaye RV, Radhika G, Nalini CN (2011) Synthesis, antioxidant and anticancer activity of quinazoline derivatives. J Current Pharma Res 1(2): $101-105$

134. Abuelizz HA, Marzouk M, Ghabbour H, Al-Salahi R (2017) Synthesis and anticancer activity of new quinazoline derivatives. Saudi Pharma J 25(7): 1047-1054 https://doi.org/10.1016/j.jsps.2017.04.022

135. Noolvi MN, Patel HM, Bhardwaj V, Chauhan A (2011) Synthesis and in vitro antitumor activity of substituted quinazoline and quinoxaline derivatives: search for anticancer agent. Eur J Med Chem 46(6):2327-2346 https://doi. org/10.1016/j.ejmech.2011.03.015S

136. Madhavi S, Sreenivasulu R, Yazala JP, Raju RR (2017) Synthesis of chalcone incorporated quinazoline derivatives as anticancer agents. Saudi Pharma J 25(2):275-279 https://doi.org/10.1016/j.jpss.2016.06.005

137. Ahmed MF, Belal A, Youns M (2015) Design, synthesis, molecular modeling and anti-breast cancer activity of novel quinazolin-4-one derivatives linked to thiazolidinone, oxadiazole or pyrazole moieties. Med Chem Res 24(7): 2993-3007 https://doi.org/10.1007/s00044-015-1357-1

138. Paul K, Sharma A, Luxami V (2014) Synthesis and in vitro antitumor evaluation of primary amine substituted quinazoline linked benzimidazole. Bioorg Med Chem Lett 24(2):624-629 https://doi.org/10.1016/j.bmcl.2013.12. 005

139. Sharma A, Luxami V, Paul K (2013) Synthesis, single crystal and antitumor activities of benzimidazole-quinazoline hybrids. Bioorg Med Chem Lett 23(11):3288-3294 https://doi.org/10.1016/.jbmcl.2013.03.107

140. Kovalenko SI, Antypenko LM, Bilyi AK, Kholodnyak SV, Karpenko OV, Antypenko OM, Mykhaylova NS, Los TI (2013) Synthesis and anticancer activity of 2-(alkyl-, alkaryl-, aryl-, hetaryl-)-[1, 2, 4] triazolo [1, 5-c] quinazolines. Scientiapharmaceutica. 81(2):359-392 https://doi.org/10.3797/ scipharm.1211-08

141. Kang M, Kim MS, Kim JY, Shin YJ, Song JY, Jeong JH (2015) A novel pyridothieno-pyrimidine derivative activates p53 through induction of phosphorylation and acetylation in colorectal cancer cells. Int J Oncol 46(1): 342-350 https://doi.org/10.3892/ijo.2014.2720

142. Mousavi SH, Atapour-Mashhad H, Bakavoli M, Shiri A, Akbarzadeh M, Tayarani-Najaran Z (2015) Pyrimidooxadiazine and triazolopyrimidooxadiazine derivatives: synthesis and cytotoxic evaluation in human cancer cell lines. Russ J Bioorg Chem 41(2):201-208 https://doi.org/1 $0.1134 / \$ 1068162015020077$

143. Nemr MT, AboulMagd AM (2020) New fused pyrimidine derivatives with anticancer activity: synthesis, topoisomerase II inhibition, apoptotic inducing activity and molecular modeling study. Bioorg Chem 103:104134 https://doi. org/10.1016/j.bioorg.2020.104134

144. Mallavadhani UV, Chandrashekhar M, Nayak VL, Ramakrishna S (2015) Synthesis and anticancer activity of novel fused pyrimidine hybrids of myrrhanone C, a bicyclic triterpene of Commiphoramukul gum resin. Mol Divers 19(4):745-757 https://doi.org/10.1007/s11030-015-9621-3

145. Addepalli Y, Yang X, Zhou M, Reddy DP, Zhang SL, Wang Z, He Y (2018) Synthesis and anticancer activity evaluation of novel azacalix [2] arene [2] pyrimidines. Eur J Med Chem 151:214-212 https://doi.org/10.1016/j. ejmech.2018.02.079

146. Sun C, Chen C, Xu S, Wang J, Zhu Y, Kong D, Tao H, Jin M, Zheng P, Zhu W (2016) Synthesis and anticancer activity of novel 4-morpholino-7, 8-dihydro$5 \mathrm{H}$-thiopyrano $[4,3-\mathrm{d}]$ pyrimidine derivatives bearing chromone moiety. Bioorg Med Chem 24(16):3862-3869 https://doi.org/10.1016/.jbmc.2016.06. 032

147. Zhu W, Sun C, Xu S, Wu C, Wu J, Xu M, Zhao H, Chen L, Zeng W, Zheng P (2014) Design, synthesis, anticancer activity and docking studies of novel 4morpholino-7, 8-dihydro-5H-thiopyrano [4, 3-d] pyrimidine derivatives as mTOR inhibitors. Bioorg Med Chem 22(24):6746-6754 https://doi.org/10.101 6/j.bmc.2014.11.003

148. Hossam M, Lasheen DS, Ismail NS, Esmat A, Mansour AM, Singab AN, Abouzid KA (2018) Discovery of anilino-furo [2, 3-d] pyrimidine derivatives as dual inhibitors of EGFR/HER2 tyrosine kinase and their anticancer activity. Eur J Med Chem 144:330-348 https://doi.org/10.1016/j.ejmech.2017.12.022

\section{Publisher's Note}

Springer Nature remains neutral with regard to jurisdictional claims in published maps and institutional affiliations. 